\title{
Why Do Some CEOs Work for a One-Dollar Salary?
}

\author{
Gilberto Loureiro \\ School of Economics and Management \\ University of Minho \\ Braga, 4710-057, Portugal
}

Anil K. Makhija

Fisher College of Business

The Ohio State University

Columbus, Ohio 43210, USA

\author{
Dan Zhang \\ Erasmus School of Economics \\ Erasmus University Rotterdam \\ Rotterdam 3000 DR, Netherlands
}

March 19, 2011

\begin{abstract}
We find evidence consistent with the view that \$1 CEO salaries are a ruse hiding the rentseeking pursuits of CEOs adopting these pay schemes. CEOs with these arrangements, despite the drastic cuts in salary, have total compensation that is similar to that at other firms, making up lost salary through not-so-visible forms of equity-based compensation. There is greater likelihood of a \$1 CEO salary when the CEO is rich, overconfident, owns a sizeable ownership stake, and institutional ownership is relatively low. These powerful CEOs are in a position to draw significant undue private benefits, and need not replace certain salary dollars with risky future income. However, we find that they are at risk of engendering public outrage over their private benefits, against which the $\$ 1$ salary constitutes valuable deflection of attention. Shareholders of firms with $\$ 1$ CEO salaries do not fare well in the aftermath of these adoptions. Thus, rather than being the sacrificial acts they are projected to be, our findings suggest that adoptions of \$1 CEO salaries are opportunistic behavior of the wealthier, more overconfident, influential CEOs. Overall, these findings support the Managerial Power Hypothesis in the literature, which claims that CEOs employ camouflage in compensation schemes to avoid public outrage over excessive private benefits.
\end{abstract}

\section{JEL Classification: G30, G32, G34}

Key words: $\mathrm{CEO}$ compensation, $\mathrm{CEO}$ characteristics

Corresponding author: Anil K. Makhija, 700 E Fisher Hall, Fisher College of Business, The Ohio State University, Columbus, OH 4320, USA. Makhija.1@osu.edu. (614) 292-1899. We appreciate helpful comments from Ulf Axelson, Uri Ben-Zion, Jennifer Carpenter, Ingolf Dittmann, Kose John, Garen Markarian, Stephen Sapp, Francesca Silvestrini, René Stulz, Moqi Xu, David Yermack, Scott Yonker, Manuel Vasconcelos (discussant at the PFN 2010 meetings), and the seminar participants at Universidade do Minho, Universidade Nova de Lisboa, and Faculdade de Economia do Porto. We thank Rudiger Fahlenbrach for giving us data on founders. Excellent research assistance was provided by Abdulrahman Almalik, Andrew Hom, and Jongha Lim. 


\title{
Why Do Some CEOs Work for a One-Dollar Salary?
}

\begin{abstract}
We find evidence consistent with the view that \$1 CEO salaries are a ruse hiding the rentseeking pursuits of CEOs adopting these pay schemes. CEOs with these arrangements, despite the drastic cuts in salary, have total compensation that is similar to that at other firms, making up lost salary through not-so-visible forms of equity-based compensation. There is greater likelihood of a \$1 CEO salary when the CEO is rich, overconfident, owns a sizeable ownership stake, and institutional ownership is relatively low. These powerful CEOs are in a position to draw significant undue private benefits, and need not replace certain salary dollars with risky future income. However, we find that they are at risk of engendering public outrage over their private benefits, against which the $\$ 1$ salary constitutes valuable deflection of attention. Shareholders of firms with \$1 CEO salaries do not fare well in the aftermath of these adoptions. Thus, rather than being the sacrificial acts they are projected to be, our findings suggest that adoptions of \$1 CEO salaries are opportunistic behavior of the wealthier, more overconfident, influential CEOs. Overall, these findings support the Managerial Power Hypothesis in the literature, which claims that CEOs employ camouflage in compensation schemes to avoid public outrage over excessive private benefits.
\end{abstract}

\section{JEL Classification: G30, G32, G34}

Key words: $\mathrm{CEO}$ compensation, $\mathrm{CEO}$ characteristics 


\section{Why Do Some CEOs Work for a One Dollar Salary?}

Gray: "Why are you cutting your salary to $\$ 1$ ?"

Mackey: "...I have enough money, and the deeper motivations are for me to do service and try to do good in the world...."

Gray: "How much of your salary cut decision has something to do with decelerating samestore sales growth?"

Mackey: "None. Zero."

From interview of Mr. John Mackey, CEO of Whole Foods, with Steven Gray (Wall Street Journal, Dec. 4, 2006, Section B, 1-3).

\section{Introduction}

Even as scholars debate whether U.S. CEOs are drawing excessive compensation (Frydman and Jenter, 2010, Frydman and Saks, 2008, and Gabaix and Landier, 2008), why have some CEOs settled for a mere dollar-a-year salary? Recently, in the wake of the worst economic downturn in decades, the CEOs of all three major U.S. automakers pledged to work for an annual salary of just a $\$ 1$. This presumably sacrificial step, to share the pain with shareholders and employees, is not unique to economic crises, however. Scores of CEOs, including those with thriving firms like Apple and Google, have also adopted this compensation arrangement since the early 1990s. In fact, the first striking feature about firms with \$1 CEO salaries is their banality: Many of these firms are household names, and are drawn from a very wide variety of industries (see Appendix A). In this paper, we address a number of unanswered questions regarding this apparently contrarian behavior.

Specifically, we ask the following questions about adoptions of \$1 CEO salaries: What are the motivations behind these adoptions? Are these adoptions merely publicity gimmicks to divert attention from other enormous, less visible payoffs in the form of bonus, stocks or options? ${ }^{1}$ What is special about these CEOs and their firms that led them to adopt uncommon salary scheme? Why are adoptions of $\$ 1$ CEO salaries rare and temporary? Importantly, how

\footnotetext{
${ }^{1}$ In an oft repeated position in the media, Scott Mayerwotitz (2008) of $A B C$ News notes that some of the $\$ 1$ salary CEOs "earned millions of dollars through stocks and other forms of compensation." For example, Scott DeCarlo (2007) notes in Forbes that Steve Jobs of Apple was the highest paid boss among the 500 firms they tracked: "He drew a nominal $\$ 1$ salary but realized $\$ 647$ million from vested restricted stock last year."
} 
do these CEOs and their shareholders fare in the aftermath of these adoptions? Altogether, the answers would address an overarching question about these adoptions: Are they the result of arm's length bargaining between boards and CEOs seeking to minimize managerial agency costs and obtain optimal compensation contracts, or are they driven by the rent-seeking motives of CEOs? These alternatives sum up contrasting views of adoptions of \$1 CEO salaries, drawn from the two main approaches to executive compensation.

According to the traditional approach based on the principal-agent framework, 'the optimal contracting approach', the board uses compensation schemes to provide the CEO with efficient incentives to maximize shareholder value (see surveys of extensive work on this by Murphy, 1999, and Core, Guay, and Larcker, 2001). Market forces and effective corporate governance help enforce the optimal contract. In the competing approach, 'the managerial power approach,' executive compensation is not necessarily a part of the solution to the managerial agency problem, but is itself a potential problem as a mechanism for rent-seeking in the hands of powerful CEOs (Bebchuk, Fried, and Walker, 2002). What constrains the board from allowing, and the powerful CEO from seeking, unbounded excessive compensation is the public outrage it might engender. There are serious social and professional costs to board members and CEOs who are highlighted by the media for excessive pay. ${ }^{2}$ Negative publicity can damage a firm's reputation, which is a signal of its product quality and affects its financial performance (Milgrom and Roberts, 1982, Michalisin, Kline, and Smith, 2000, and Roberts and Dowling, 2002). To soften this "outrage constraint," and facilitate rent extraction, the CEO may seek to camouflage excessive compensation. ${ }^{3}$ This has also been referred to as the "skimming" view of executive compensation (Yermack, 1997, Bertrand and Mullainathan, 2001, Bebchuk, and Fried, 2004, and Kuhnen and Zweibel, 2006), according to which CEO compensation is fraught with distortions by entrenched managers to achieve stealth compensation: "When

\footnotetext{
${ }^{2}$ E. g., Johnson, Porter, and Shackell (1997) report that CEOs with adverse media coverage subsequently received smaller pay increases. Similarly, according to Thomas and Martin (1999), CEOs, who were targets of shareholder resolutions criticizing executive pay, saw their annual compensation reduced dramatically in the following two years.

${ }^{3}$ Consistent with Weisbach (2007), Kuhnen and Niessen (2010) document that following negative press of CEO pay, firms have reduced option grants, which have been the focus of adverse public attention recently, and increased the less controversial forms like stock awards.
} 
changing circumstances create an opportunity --either by changing outrage costs and constraints or by giving rise to a new means of camouflage-- managers will take full advantage of it..." (Bebchuk, Fried, and Walker, 2002). ${ }^{4}$ For example, by increasing the less obvious equity-based grants, and smaller gains in cash salary, CEOs managed to obtain much greater incomes during the boom of the 1990s without incurring the ire of shareholders (Bebchuk and Fried, 2003). From the perspective of these two approaches, we examine whether $\$ 1$ CEO salaries are a move towards optimal contracts, or are they camouflage to avoid outrage about excessive rents.

We formulate and test three hypotheses, highlighting different salient features of adoptions of $\$ 1 \mathrm{CEO}$ salaries in light of the approaches to executive compensation in the literature: First, according to an Alignment Hypothesis based on the 'optimal contracting approach,' a \$1 CEO salary may better align CEO-shareholder interests and produce more efficient incentives (Hart and Holmstrom, 1987, Core, Guay and Larcker, 2003). Second, in the spirit of Leland and Pyle (1977) in another application of the 'optimal contracting approach,' according to a Signaling Hypothesis we emphasize the willingness of some CEOs to suffer certain current loss of salary in exchange for substantial equity-based risky payoffs later. Shareholders are expected to benefit from adoptions of $\$ 1$ CEO salaries, according to both the Alignment and Signaling Hypotheses. In contrast to the 'optimal contracting approach,' a rent extraction view defines our third hypothesis, the Managerial Power Hypothesis. Now, \$1 CEO salaries are not consistent with shareholder value maximization. In this view, the compensation contract is not the result of vigorous arm's length bargaining, but is instead designed to serve the CEO's personal goals. The $\$ 1$ CEO salary may be a form of camouflage to avoid outrage over excessive total compensation or a diversion of attention from other self-serving activities of the CEO. Besides camouflage which obfuscates the true nature of their benefits, CEOs may be taking other preventive measures to pacify or avoid outrage from stakeholders. ${ }^{5}$ Instead of

\footnotetext{
${ }^{4}$ Core, Guay, and Thomas (2005) and Edmans and Gabaix (2009) have countered Bebchuk and Fried's view by arguing that the controversial practices can be reconciled with the optimal contracting view.

${ }^{5}$ Myers (2000) develops a model in which managers must pay a minimum dividend or face retaliation from shareholders. Bertrand and Mullianathan (2003) note that when they are not closely monitored, "managers prefer to pay higher wages to employees than profit-maximizing shareholders do. High wages
} 
seeing it narrowly as a form of subterfuge to garner just excessive compensation, we view the camouflage value of adoptions of \$1 CEO salaries as shielding other self-serving behaviors as well. Projected as sacrificial acts, these adoptions can serve as a façade behind which the seemingly selfless CEO can hide, not only large non-salary compensation, but also other undue personal benefits from the firm. We elaborate on these hypotheses further.

We begin with the first explanation, the Alignment Hypothesis. As a compensation decision normatively set to provide the CEO with incentives that minimize managerial agency costs and lead to the maximization of shareholders' wealth, a \$1 CEO salary shifts compensation to a largely equity-based form. It can consequently better align the interests of the CEO with those of shareholders, as well as incent him through grants of options to undertake risky growth opportunities. It has been argued that more options-heavy contracts increase the incentives to exploit risky growth opportunities (Core and Qian, 2001). ${ }^{6}$ Thus, from the perspective of optimal contracting theory, we expect that firms in greater need of alignment between shareholders and their CEOs (greater managerial agency problems), and firms in possession of more growth options, are more likely candidates for adopting a dollar-a-year CEO salary. These predictions of the Alignment Hypothesis, along with those of the other hypotheses, are summarized in Table 1.

It is, however, unlikely that we are simply looking at ordinary variation in compensation structure, except that the salary component has been dropped to its lowest limit. If a \$1 CEO salary is the preferred mechanism to deal with managerial agency problems in such commonplace firms, then this compensation choice should be far more common. Rather adoptions of $\$ 1 \mathrm{CEO}$ salaries may be an appropriate contracting response to an urgent business challenge faced by the firm. Arguably, firms adopting \$1 CEO salaries face serious concerns about their prospects (either dire or loss of highly valuable opportunities), and these adoptions are a radical signaling response to these situations. Only a capable CEO candidate would step forward to take a $\$ 1$ salary "bet," agreeing to a certain sizeable drop in current income in

can also make a manager's job easier by reducing turnover, reducing the need for bargaining effort in a union context, or simply buying "peace" from workers" (p. 1058).

${ }^{6}$ Though heavily in-the-money options have largely similar incentives as stocks. 
exchange for a potential uncertain reward later. In essence, by accepting the bet, the CEO signals ability and wins the opportunity to execute his, possibly controversial, turnaround plan. This Signaling Hypothesis predicts that \$1 CEO salaries are adopted by well-governed firms, facing challenging prospects, with able CEOs who have "skin in the game."

An alternative hypothesis, the Managerial Power Hypothesis, does not take a favorable view of $\$ 1$ CEO salaries from the shareholders' perspective. The reason why some firms adopt \$1 CEO salaries can be attributed to CEOs who are interested in the compensation and other economic benefits that they can draw behind the smokescreen of these arrangements. By eliminating salary, the most visible form of compensation, the CEO may deflect attention from the other forms of pay, e. g., stocks and options. But, the camouflage value of $\$ 1$ salaries may go beyond their usefulness in extracting rents through compensation. As a seemingly altruistic action, \$1 CEO salaries may also reduce the likelihood of outrage over his other behaviors, providing the $\mathrm{CEO}$ with the cover to draw other private benefits and pursue a personal agenda harmful to shareholders. This is a broader view of the camouflage value of $\$ 1 \mathrm{CEO}$ adoptions. In fact, relative to the extra dollars of compensation that he may get away with because of the $\$ 1$ salary, arguably the other personal pursuits of the CEO may well be more expensive for shareholders. These other activities may include personally-preferred investments, heavy perk consumption, nepotistic appointments, favored charities, etc. Moreover, the $\$ 1$ salary, even if chosen only for its camouflage value for compensation purposes, may also be distortive because it does not provide optimal incentives to the CEO. We do not expect the firm to be wellgoverned, since the CEO prevails in adopting a value-destroying agenda. The $\$ 1 \mathrm{CEO}$ is part of the power dynamics that results from strong CEOs with weak boards. We expect the firm to underperform as a result.

Thus far, we have drawn upon rational economic motives for the Managerial Power Hypothesis. But, given the nature of the problem, it is natural to wonder if behavioral biases also play a complementary role. Consequently, we consider personal traits of the CEO and extend the Managerial Power Hypothesis to include adoptions motivated by behavioral biases. In particular, we examine whether CEOs that want a $\$ 1$ salary are perhaps overconfident of their 
abilities (Malmendier, Tate, and Yan, 2010), and thus too willing to accept a bad gamble. Though possibly well-intentioned, their "good faith mismanagement" is nevertheless valuedestroying, and can prevail only if the CEO is strong and the board is weak. Similarly, because \$1 salaries attract considerable personal publicity and enhance his social status, a CEO may favor these adoptions, even if not in the best interests of shareholders. Since the rich may be more prone to favor such non-monetary consumption over some incremental salary dollars as the interview with Mr. Mackey quoted at the top of this article suggests, we also consider the wealth of the CEO. Of course, we cannot rule out the possibility that the $\$ 1$ salary was meant to mute criticism of Mr. Mackey despite the problems faced by Whole Foods, allowing him to continue with his "do good" agenda. Albeit arising out of behavioral biases or economic preferences, the CEO's value-destroying and self-serving schemes can provoke outrage, for which the $\$ 1$ salary is preventive insurance.

We identify 50 genuine cases of firms with $\$ 1$ CEO salaries over the years, 1992-2005. ${ }^{7}$ First of all, these drastic cuts in salary seem to hide other forms of compensation since we find that the resulting total compensation, inclusive of bonus, stock, and options awards, is similar to that at other firms. Furthermore, we find that there is greater likelihood of a $\$ 1$ CEO salary arrangement if the CEO owns a sizeable ownership stake in the firm, and institutional ownership is relatively low. Arguably, this provides the CEO sufficient power to at least draw a proper salary, with no need to cut it or replace it with risky income, except to preempt public outrage with a seemingly selfless act. But, there is also evidence that the camouflage of a \$1 CEO salary is valuable for these CEOs since we document that many $\$ 1$ CEOs are at risk of being targets of public outrage, which is when notions of fairness and equity are thwarted. Public outrage can take the form of media coverage, shareholder resolutions, government inquiries, investor activism, threats against executives or the firm, etc. We also document that the potential for outrage has subsided in the year following the dropping of the $\$ 1$ CEO salary.

\footnotetext{
${ }^{7}$ In many cases, ExecuComp, a widely used database in empirical work on executive compensation, reports no salary in the Annual Compensation table in the proxy statement. But, a closer reading of the footnotes in the proxy statement reveals that the CEO is well-compensated through an affiliated enterprise or was prepaid in a previous year.
} 
Importantly, the firm does not fare well in the aftermath of adoptions of $\$ 1 \mathrm{CEO}$ salaries. These findings support the Managerial Power Hypothesis. There is also supporting evidence of behavioral biases that seem to motivate these CEOs to adopt $\$ 1$ salaries. Even against other CEOs who tend to be overconfident, we find that \$1 CEOs are significantly more overconfident. Moreover, though CEOs also tend to be rich in general, $\$ 1$ CEOs are even richer still. One can conjecture that the very rich, like Mr. Mackey, are more likely to pursue non-monetary personal pursuits, which are not necessarily in the best interests of shareholders.

This study offers several contributions. Though it affects only a few firms, this study examines an unaddressed, highly publicized, phenomenon affecting familiar firms. It also adds to our understanding of the efficiency of executive compensation, and hence to the ongoing heated debate on the relative importance of the optimal contracting and managerial power approaches. There are other unique advantages as well. Studies of executive compensation routinely assume the traditional compensation format in which salary is the main pillar, with other components of compensation like target bonuses, options grants, defined pension benefits, and even severance arrangements typically expressed as a percentage or a multiple of base salary (Murphy, 1999). In contrast, our study illustrates the unexamined motivations and consequences in a case where the traditional format is abandoned.

There are serious consequences from assuming that the traditional compensation format applies to all firms. In particular, recent studies bring out the shortcomings of ignoring \$1 CEO salaries in studies of CEO compensation. For example, Guthrie, Sokolowsky, and Wan (2010) show that the findings of Chhaochharia and Grinstein (2009) are upturned when just two "outliers" - both cases of \$1 CEO salaries in our sample, Steve Jobs of Apple and Kosta Kartosis of Fossil - are removed from the analysis. We document many more cases of \$1 CEO salaries, which too do not fit the usual mode of CEO compensation.

This study also adds to work that focuses on special subsets of CEOs. In that sense, this paper follows a similar approach to that taken by Malmendier and Tate (2009), who study "Superstar CEOs". This closer, more detailed approach permits one to take into account the heterogeneity of characteristics among CEOs, which may be useful in understanding the 
behavior of firms according to a growing literature that links CEO characteristics with the policies and outcomes of firms (Bertrand and Schoar, 2003, Schoar, 2007, Graham, Harvey, and Puri, 2009, and Kaplan, Klebanov, and Sorensen, 2008, Malmendier, Tate, and Yan, 2010, and Cronqvist, Makhija, and Yonker, 2011).

In the next section, Section 2, we develop several hypotheses regarding the motivation for adopting a dollar-a-year CEO salary. To test these hypotheses, in Section 3 we identify and describe our sample. For factors that motivate the adoptions of $\$ 1 \mathrm{CEO}$ salaries, we test the Alignment Hypothesis in Section 4, and the Signaling and Managerial Power Hypotheses in Section 5. We examine the role of CEO overconfidence in the adoptions of $\$ 1 \mathrm{CEO}$ salaries in Section 6. The value effects of these adoptions are considered in Section 7. We document in Section 8 the reasons why the CEOs with $\$ 1$ salaries are at risk of public outrage over their private benefits, including compensation. In Section 9, we undertake a number of robustness checks and discuss further the implications of our findings. We offer concluding remarks in Section 10.

\section{Hypotheses and their tests}

To better understand the context in which firms adopt $\$ 1$ CEO salaries, we begin by reading proxy statements for the first year of adoption. ${ }^{8}$ Appendix A presents related excerpts from proxy statements for some 50 firms that are the basis of our later empirical analysis. Table 2 draws upon this information to highlight certain aspects of these adoptions.

In Panel $\mathrm{A}$ of Table 2, we note that the two most frequently cited reasons for adopting $\$ 1$ salaries are to align the interests of CEOs with shareholders, and to aid in the restoration of profitability.

\footnotetext{
${ }^{8}$ Interestingly, corporate law has historically been largely silent on how much and in what manner executives should be compensated, though the recently passed Dodd-Frank Act of 2010 is about to introduce advisory "say on pay" voting by shareholders. These decisions by default are left to the board. Similarly, exchange listing requirements place only procedural restrictions on pay, such as the NYSE rule that stock option plans be approved by shareholders. Government and other regulations are generally focused on disclosure requirements.
} 
In Panel $\mathrm{B}$, we see that the reduction in salary to $\$ 1$ is overwhelmingly accompanied by a reduction in bonus as well ( $88 \%$ of the cases), effectively eliminating meaningful current cash payoffs. Furthermore, a large proportion of the CEOs in our sample receive some equity-based compensation (78\%), and that in many cases the firm actually notes that this compensation has been provided in lieu of lost salary and bonus. The exchange may be implied in other cases. This supports the view that a $\$ 1$ salary may not necessarily imply a sacrifice, and motivates us to later examine total compensation.

Panel C shows that in about half the cases (46\%) the appointment of the CEO occurs simultaneously with the adoption of a $\$ 1$ salary arrangement. This is highly suggestive of a quid pro quo deal, whereby the CEO pays in lost salary and bonus in exchange for the opportunity to lead the firm and get any benefits that may accrue to him in the future from the stocks and options granted to him. Incumbent CEOs that change to a $\$ 1$ salary arrangement may be accepting similar bargains to hold on to their jobs, and be allowed the opportunity to execute their preferred turnarounds. Or, it is a preventive measure against criticism of the new CEO's package and plans.

Next, we rely on the information in proxy statements, as well as media coverage and the literature, to formulate three hypotheses, Alignment, Signaling, and Managerial Power Hypotheses, for why some CEO salaries are set at $\$ 1$.

\subsection{Alignment Hypothesis}

Interestingly, a sizeable number (38\% of all cases, Panel A of Table 2) of firms offer no explicit reason for the adoption in their proxy statements. However, when they do, the most frequent reason ( $40 \%$ of all 50 cases) is that a $\$ 1$ salary helps align the interests of the CEO and shareholders by shifting compensation to a more stock- or option-based form. ${ }^{9}$ Thus, the $\$ 1$ CEO salary is frequently accompanied by equity-based compensation, (78\%, in Panel B), with

\footnotetext{
${ }^{9}$ The media has noted this too. Writing in Business Week, Moira Herbst (2007) calls it the ultimate payfor-performance scheme, where CEOs are "sending the message to investors that they'll make money only if other shareholders do, too."
} 
options grants in $70 \%$ of all cases. The following examples, all from proxy statements (Form

DEF 14a) illustrate this (underlying added here and below for emphasis):

Extended Stay America, Inc., George D. Johnson, Jr., 2000. "The Company does not pay Mr. Johnson any cash salary or bonus but rather compensates him exclusively through stock option grants. We believe that tying Mr. Johnson's remuneration to the performance of the Company's Common Stock will motivate Mr. Johnson to maximize stockholder value and is consistent with our policy of compensating the Company's senior executives, like Messrs. Huizenga and Johnson, primarily through annual stock option grants."

In many of these cases, the firm explicitly notes that the equity-based compensation was

in lieu of the foregone salary and bonus:

AES Corp., Dennis W. Bakke, 1999. “The Committee decided that, beginning in 1999, Mr. Bakke would no longer receive cash as part of his overall compensation. Mr. Bakke was compensated solely by the grant of stock options (in lieu of a cash salary and cash bonus). The Committee believes that this method of compensation will align Mr. Bakke's compensation more closely with the financial interests of the Company's other shareholders."

In a few cases, the firm offered the exchange of salary and bonus as an option left to the discretion of the CEO:

Bombay Co., Inc., James D. Carreker, 2003. "Pursuant to his employment agreement, he was entitled to receive a base salary of $\$ 600,000$ or, if he elected to receive his base salary in the form of restricted stock vesting in full at the end of three years, he was entitled to a grant of restricted stock valued at 1.25 times base salary. He elected to take stock and was granted 81,256 shares. At January 30, 2004, the shares had a value of $\$ 611,858$. Similar elections may be made each year on or about the anniversary date of Mr. Carreker's appointment."

And then, there are cases where the salary is dropped because the CEO has a large ownership stake and thus automatically has interests aligned with shareholders:

Netscape Communications Corp, James L. Barksdale, 1997. "For 1997, Mr. Barksdale elected to receive a salary of $\$ 1.00$ and to return an option grant of 300,000 shares made in April 1997. Mr. Barksdale believes that his compensation should be linked to the long-term interests of Netscape's stockholders. Accordingly, through his ownership position in Netscape's Common Stock, Mr. Barksdale's pecuniary interests are aligned with those of Netscape's stockholders."

The finance literature recognizes the potential benefits from an improved alignment of interests of the CEO and shareholders. Along with how much the CEO is paid, it is also important how he is paid, so that the structure of compensation matters to CEO behavior (Jensen and Murphy, 1990). According to traditional agency models, a larger equity-based compensation makes the $\mathrm{CEO}$ behave more like stockholders, and reduces the agency cost of equity (Jensen and Meckling, 1976). Moreover, since we see more of a shift towards larger options-based compensation rather than stock awards, we also raise the (implied) possibility that 
the purpose of $\$ 1$ CEO salary is to incent the CEO to take on greater risks and benefit the firm from its growth opportunities (Smith and Watts, 1992). While alignment of CEO-shareholders interests and exploitation of growth opportunities are in principle desirable objectives across the board, only adopting firms take on extreme measures in formulating their compensation structures. Any number of reasons, including product market developments, could aggravate agency problems, and precipitate a need for adopting \$1 CEO salaries. Thus, our agency-based prediction is the following:

Alignment Hypothesis: One-dollar CEO salaries are adopted by firms in greater need of alignment of CEO-shareholders interests and/or in possession of more growth options. The adoption reduces managerial agency costs and creates shareholder value.

These predictions are laid out in Table 1: According to the Alignment Hypothesis, (a) the motivating factor for the adoptions is the presence of greater managerial agency problems, (b) the corporate governance of the firm is effective, and (c) the adoptions of $\$ 1$ CEO salaries are value-creating for shareholders.

\subsection{Signaling Hypothesis}

Of course, it should not be surprising that in the proxy statements, which are meant to garner their votes, that firms would most emphasize the shareholders' perspective in the adoption of \$1 CEO salaries. But, adoptions of \$1 CEO salaries also require the risk-averse CEOs to accept riskier compensation packages, exchanging certain current income in exchange for an uncertain future reward. Only those CEO candidates would accept such packages that have the confidence in their ability to deliver. In a handful of cases $(6 \%)$, the proxy statements literally voice this very confidence, typically in the context of performance problems:

Lily (Eli) \& Co, Sidney Taurel, 2002. "In light of the reduction in the company's Prozac sales, Mr. Taurel voluntarily reduced his base salary to $\$ 1.00$ for the year 2002. The company did not offset this reduction in salary by any additional compensation but provided a benefits allowance to preserve his employee benefits at their normal level. Mr. Taurel requested this reduction to demonstrate his confidence in the company's future results and to set an example for employees." 
In many more cases (24\%), the CEO gave up his salary to reduce costs and aid in the recovery of the firm, again effectively betting on the future: ${ }^{10}$

Cisco Systems, Inc., John T. Chambers, 2002. "On April 1, 2001, Mr. Chambers requested that his base salary be lowered to a rate of $\$ 1.00$ annually (until the recognition of a recovery in Cisco's performance). On May 11, 2001, the Committee agreed to honor this request until such a time as the Committee deems it appropriate to return Mr. Chambers' base salary to a market competitive level. For fiscal year $2002 \mathrm{Mr}$. Chambers' base salary remained at $\$ 1.00$."

In other cases, the CEO may bet on adding significantly more value to an already profitable firm, with behaviorally similar implications regarding betting on the future as entailed in restoring profitability. Though this is a plausible situation, as perhaps in the cases of Apple and Google, Panel A of Table 2 suggests that restoration of profitability is likely a much more common reason for adoptions of $\$ 1 \mathrm{CEO}$ salaries than the upside bet on the exploitation of large growth options.

We expect that only capable CEO candidates will signal an ability to successfully carry out a turnaround, or else they irrationally enter into a proposition with an expected loss. Moreover, well-functioning boards will go forward with these arrangements with only deserving candidates, or else they accept a losing proposition for their shareholders. For the signal to be credible, the CEO must have a sufficient stake in the outcome to be handed over the reins of the firm. ${ }^{11}$

Signaling Hypothesis: One-dollar salaries are adopted by well-governed firms to identify credible CEOs who can successfully address the concerns about the firms' prospects. The adoption signals value creation for shareholders.

These predictions are laid out in Table 1: According to Signaling Hypothesis, (a) the motivating factor is a business challenge, poor performance or realization of growth opportunities, (b) the corporate governance of the firm is effective, and (c) adoptions of \$1 CEO salaries are value-creating for shareholders.

\footnotetext{
${ }^{10}$ For the Signaling Hypothesis and the bet it entails, there is indeed some evidence in the proxy statements and press releases made by the firms (Factiva and Lexis/Nexis) that they are facing some challenges. Some $17(34 \%)$ firms are actively engaged in restructuring in the period surrounding the adoption of a $\$ 1$ CEO salary. If we increase the window, from $(-1,+1)$ to $(-3,+3)$ years, $23(46 \%)$ of the firms are restructuring. Besides reading the proxy statements and 10Ks, we made searches on restructure (-ing)/reorganize (-ing/-ation)/turnaround/ costcut (-ing)/pay(salary /wage/payroll) cut and lay(laid) off /sack for this purpose.

${ }^{11}$ The Signaling Hypothesis is closely related to the Alignment Hypothesis, and could be seen as a special case of it during a "turnaround" period.
} 


\subsection{Managerial Power Hypothesis}

The starting point now is that the CEO has considerable influence over the design of his compensation package to adopt schemes that benefit him. ${ }^{12}$ Obviously, the proxy statements of firms adopting \$1 CEO salaries do not point out that these schemes can be harmful to shareholders. Yet, the adoptions of $\$ 1 \mathrm{CEO}$ salaries may be driven by the desire to camouflage personal agendas of the CEOs, and may not maximize shareholders' wealth. With public attention diverted towards the reduction in salary, the CEO may continue to enjoy large compensation through additional stocks and options. He can also protect other benefits from the firm. Indeed, the proxy statements do mention personal motives, e.g., funding of favored charitable causes, that may have prompted some CEOs to seek these salary arrangements. See for example:

Pepsico, Inc., Roger A. Enrico, 1998. “At Mr. Enrico's request, the Committee approved a reduction in Mr. Enrico's annual salary from $\$ 900,000$ to $\$ 1$, and recommended to the Board of Directors that it consider using the savings to support front line employees(scholarship for children of PepsiCo's sales people, truck drivers, manufacturing plant workers and other front line employees). In January 1999/2000, the Board approved annual charitable contributions of approximately $\$ 1,000,000$ to fund additional scholarships for children of PepsiCo's front line employees."

Besides protecting a general mindset that is not focused on shareholders, adoptions of $\$ 1$ salaries may be at a cost to firm performance because it may not be the optimal incentive scheme. The $\$ 1$ salary can also be directly personally beneficial to the CEO. As the CEO of Palm Pilot, Carl Yankowski (2006) put it in Marketplace, "No question, the \$1 salary is good personal marketing that's worth a fortune in publicity." If motivated by such personal pursuits, approval of the $\$ 1$ CEO salary and the value destruction that follows presumes a failure of corporate governance. The wealthier individuals are more likely to seek the psychic pleasure of public service for its own sake, and the social recognition it engenders, instead of being tainted by the monetary gains associated with being a paid CEO.

\footnotetext{
${ }^{12}$ Out of the 50 adoptions of $\$ 1$ CEO salaries in our sample, we are able to discern who initiated the scheme in 35 cases. We do so by inferring from words like "volunteered," "requested," "waived," "elected," etc. We find that 30,3 , and 2 times the initiators are the CEO, compensation committee, and the board, respectively.
} 
Managerial Power Hypothesis: One-dollar CEO salaries are adopted by firms with weak governance and wealthier CEOs as camouflage for their personal agendas which are detrimental to shareholders.

These predictions are laid out in Table 1: According to the Managerial Power Hypothesis, (a) the motivating factor is the protection of private benefits (at least maintenance of total compensation, and the ability to carry out other personal agenda), (b) the corporate governance of the firm is weak, and (c) the adoptions of \$1 CEO salaries are value-destroying for shareholders. As a part of (a), we include examination of the potential reasons why there may be public outrage about the CEO's behavior, be it compensation-related or his other activities.

\section{Data}

In this section, we identify and describe our sample of firms that adopted dollar-a-year salaries, as well as a control group of firms.

\section{1. Identification of sample and control firms, and sources of data}

$\underline{\text { Sample identification }}$

We use the entire ExecuComp/Compustat database, as of the end of 2005 to identify all CEOs that at some point in time worked for a \$1 salary or less. Spanning the period, 1992 to 2005, there were a total of 100 such " $\$ 1$ " CEOs in the database. We started in 1992 because that is when ExecuComp compensation data starts. We stopped in 2005 so that we could examine the post-adoption performance in the following years (long-term performance). This way, only a couple of firms have a crisis year (2008) in their 3-year post-adoption performance. We dropped 24 cases because the CEOs served less than a year, frequently serving in a stated or implied interim position. Next, we read the proxy statements for the remaining 76 cases to see if these are truly $\$ 1$ salary CEOs, and qualify for inclusion in our sample. Startlingly, in very many cases this is not so. 
We clean the sample using other information in the proxy statements, eliminating CEOs who got a $\$ 0$ or $\$ 1$ salary because they were either prepaid in the previous year or are indirectly compensated by other enterprises under some special agreements. For example, the data from ExecuComp shows that Thomas W. Sturgess, the CEO of United Stationers, Inc., has a zero salary in the fiscal year 1995. However, the footnote with the compensation table in DEF 14A of United Stationers, Inc., states that, "For calendar year 1995, Mr. Sturgess received compensation from Wingate Partners, but no compensation from the Company". Due to the lack of compensation information from Wingate Partners, we do not consider Mr. Sturgess as a \$1 CEO. Similarly, Gabriel Battista from Talk America Holdings also has a zero salary for fiscal years 2000 and 2001. However, the accompanying note in the proxy statement shows that Mr. Battista's salaries for the years 2000 and 2001 were prepaid in 1999. This too is not a case of a $\$ 1$ CEO. To ensure that we do not incorrectly include such cases, we manually check the CEO compensation descriptions in 10-K or DEF 14A filings on EDGAR, paying attention to textual footnotes, for all cases initially found to have very low salaries in ЕхесиСотр. Nearly one-third of the cases (26/76) were excluded in the process, which spells a serious caveat regarding the common over-reliance in studies on executive compensation on figures from the Annual Compensation table reported in ExecuComp. We dropped 21 cases because the CEO received salary from other sources (under special arrangements). Another 4 were dropped because the CEO was paid consulting fees in lieu of salaries. And, in 1 case the salary was prepaid in a previous year. Our final sample consists of 50 cases, which with excerpts from proxy statements, are listed in Appendix A. ${ }^{13}$

It is unclear what should constitute the set of control firms. At the one end, if we form one-to-one matches, we highly overstate the probability of \$1 CEO adoptions in our subsequent probit analysis. On the other hand, if we retain all other firms in ExecuComp, which we in fact report as a robustness check for our main findings, the group of controls is too large to handcollect various items for some of the analysis. An alternative is to pick a desired number of

\footnotetext{
${ }^{13}$ In order to augment our sample size and yet retain the impact for the cover value of a $\$ 1$ or $\$ 0$ salary, we searched for cases of salary under $\$ 1000$. We find no additional cases to add to our sample, which underscores the purported ruse value of just a $\$ 1$ or $\$ 0$ salary.
} 
firms, and then randomly select that number of non-\$1 CEO salary firms in ExecuComp for a control group. Instead, we form a control group by starting with all firms in the same 4-digit SIC code in the same year as the first year of each adoption of a \$1 CEO salary. Some firms in this initial set of controls are, however, dropped for the following two reasons: one, if they are themselves \$1 CEO salary firms in another year, or two, if they are missing coverage by Compustat and CRSP. This gives us a total control group of 246 firms. While this does not constitute one-to-one matches, there is no obvious selection bias in firm characteristics against the likelihood of adopting \$1 CEO salaries. In terms of various size measures, the sample and control are similar, as discussed later. All dollar amounts in the analysis are adjusted to 2005 dollars using the CPI.

Later, as an important robustness check, we avoid any restrictions in forming the control group and use panel data with all other S\&P 1500 firms for the years 1992-2005 as the sample of control firms.

\section{$\underline{\text { Sources of data }}$}

Besides reading proxy statements, we access Compustat for accounting data, CRSP for stock market data, Thomson 13-F's for institutional ownership, and Riskmetrics (ISS) for governance and board data. We undertake various searches using a number of search engines, including Factiva. Data on founders are partly hand-collected, and the rest are from Compact Disclosure. Data on the CEO's non-firm wealth are from Dittmann and Maug (2007). ${ }^{14}$ We also utilize the Forbes 400 list to identify the richest individuals, Hoover's and Bloomberg for the education and history of individual CEOs, and to identify if a CEO was the founder of a firm. For measuring CEO overconfidence, we read articles on sample and control firms in more than a dozen media outlets, following the media-based methodology suggested by Malmendier and Tate (2005) and Malmendier, Tate, and Yan (2010).

\footnotetext{
${ }^{14}$ These data are available on line: http://people.few.eur.nl/dittmann/data.htm.
} 


\section{Incidence of \$1 CEOs}

Table 3, Panel A, shows the incidence of \$1 CEO salaries. More than two-thirds of the new cases (35) are firms that are listed on NYSE, 14 are listed on NASDAQ and only one firm (Metaldyne) is listed on the OTC market. The number of new cases is on average only about 3.5 per year, with twice that number in 1999 , the year with the most $\$ 1$ CEO salary adoptions. But, 1999 is hardly unique since several other years have just one less adoption. Even so, later we affirm our main findings with year fixed effects. The average number of $\$ 1$ CEOs out there in any year, new plus continuing, is just under 10. Given the thousands of listed firms, the phenomenon of adopting a $\$ 1 \mathrm{CEO}$ salary is rare.

Panel B of Table 3 describes the number of consecutive years CEOs in our sample took a $\$ 1$ salary. For this purpose, we go beyond the window for adoptions in our study, since in some cases the $\$ 1$ CEO salaries are still ongoing. Panel B shows that on average a CEO works for a $\$ 1$ salary for 3.16 consecutive years, which is only about $40 \%$ of the tenure of the typical Exеси Cотр CEO (Cremers and Palia, 2010). The median number of years is 2, and the mode is just 1 year (15 out of 50 cases). For about three-fourths of our sample, the CEO receives a $\$ 1$ salary for 3 years or less. While these figures suggest that $\$ 1$ CEO salaries are a temporary phenomenon for the average firm, for some firms it has the appearance of permanence, going up to 11 years in four cases.

From Panel $\mathrm{C}$ of Table 3, we observe that these firms are drawn from a very wide range of 4-digit SIC industries, revealing no notable clustering in a particular industry. Some $92 \%$ of the sample firms are solitary representatives of their industry. Only one industry has anything like a cluster, if only of five firms. But, even these firms from the prepackaged software industry did not adopt \$1 CEO salaries in the same year: Epicor Software adopted in 1995, Netscape in 1997, Zix in 1999, Oracle in 2000, and Siebel Systems in 2001. (We affirm our findings with year fixed effects and clustering by industry).

In sum, based on the incidence of adoption of $\$ 1$ CEO salary, we find that it is a rare occurrence. When it does occur, it is more common among firms listed on the NYSE with no 
discernible pattern of industrial affiliation. Though temporary for the average firm, it is longlasting in some cases.

Next, we examine various aspects of the profiles of the \$1 CEOs with \$1salaries.

\section{2. CEO profile}

\section{$\underline{\text { Personal characteristics }}$}

In Panel A of Table 4, we describe their personal characteristics. In terms of age, gender, and education, CEOs of adopting firms are not remarkably different from CEOs at control firms. The one notable difference between the two groups is that adopting CEOs are portrayed to be more "confident" by the media, which we infer from the average number of articles on sample and control CEOs in the media with "confident" depictions of CEOs. We later develop a more detailed analysis motivated by this observation, since it suggests more hubristic behavior among CEOs of our sample firms.

\section{Indications of personal wealth}

The indicators of the personal wealth of CEOs that accept a dollar-a-year salary are presented in Panel B of Table 4. Some $30 \%$ of our sample CEOs belong to the Forbes 400 list of the richest Americans, whereas less than 5\% of the control group of CEOs belongs to this elite club. There is a clear over-representation of the richest among the CEOs with $\$ 1$ salaries. In an alternative direct dollar comparison of one important source of their wealth, we rank all CEOs, those in the sample with $\$ 1$ salaries along with the CEOs in the control group, by the value of their stockholdings in the firms they head up. We then divide the list into terciles based on the highest, middle, and lowest values of stockholdings. Notably, $68 \%$ of the sample CEOs belong to the tercile with the highest value of stockholdings in comparison to only $30 \%$ of the control group CEOs. These and other comparisons of CEO wealth between the sample and control firms show that they are statistically significantly different at the $1 \%$ levels. CEOs, as represented by those in our control sample, are in general a wealthy group. Our sample CEOs are wealthier still. 
In order to assess the source of their wealth, we turn to Dittmann and Maug (2007) for estimates of non-firm wealth based on cumulating all historical cash inflows and outflows shown in ExecuComp. It would appear that the wealth of our sample CEOs is based largely on their holdings in their firm rather than non-firm wealth. One can interpret this to imply that CEOs of adopting firms have a serious commitment to the success of the firm. Alternatively, these individuals are so very rich that they are likely to seek non-monetary goals. Also, they may exert sufficient power at their firms to draw serious private benefits, and to worry about the public reaction.

\section{History with the firm}

In Panel $\mathrm{C}$ of Table 4, we present various indicators of the historical connections between the CEOs and their firms, both for CEOs working for $\$ 1$ salaries and those at firms in the control group. We see that they are no more likely to be founders than CEOs of firms in the control group. Nor are they more likely to be come-back CEOs, brought back to tide over a challenging period. In fact, at the time of the $\$ 1$ salary adoption, both the mean and median comparisons show that the CEOs that work for a dollar-a-year have served fewer years as CEO with the firm. The difference in medians is statistically significantly different at the $1 \%$ level, 1 year versus 3 years.

There are two other notable significant differences in Panel $\mathrm{C}$ of Table 4. The proportion of CEOs in their first year of appointment (first-time CEOs) for our sample firms is $46 \%$. Some 13 internal executives were promoted to CEO and simultaneously changed to $\$ 1$ salaries. Another 10 were external appointees joining with a $\$ 1$ salary. The rest, 27, were incumbent CEOs who had their salaries changed to a dollar-a-year. For the control group, only about $20 \%$ were in their first year. It appears that many CEOs in our sample are appointed with a \$1 salary. It is unlikely that the two events are independent, suggesting that the appointment and the $\$ 1$ salary arrangement are a joint event. ${ }^{15}$ The other noteworthy connection is the

\footnotetext{
${ }^{15}$ This observation is reminiscent of Khurana's (2002) claim that CEO appointments are not made in a classical labor market, but rather could be motivated by the publicity they might engender, etc.
} 
relatively large ownership stake held by our sample CEOs, about $10 \%$ versus around $3.2 \%$. Such stakes imply both greater commitment to shareholder value maximization as well as greater shareholder power for sample CEOs to pursue self-oriented objectives.

Next, we compare the characteristics of the firms whose CEOs work for a dollar-a-year salary against those working at the control group of firms.

\section{3. Characteristics of firms whose CEOs work for a dollar-a-year salary}

In Table 5, we present a comparison of a number of characteristics of our sample and control firms, including measures for size, growth, risk, capital structure, past performance, and payout policies. If we require both significant differences in mean and median, there are no remarkable differences between the two groups, except one, suggesting that the sample firms resemble the control firms. The one exception is the average ROA over the past three years. But, even this ROA for sample firms is not negative (mean (median) are 2.2\% (2.8\%) for sample versus 5.4\% (4.2\%) control firms), and all the stock price measures, LT Abnormal returns, LT CAR, or Alpha, show that the sample and control firms have similar past performance.

It is also worth noting that means and medians for size, measured as total book assets or market cap, are not statistically different between the sample and control groups of firms. According to Gabaix and Landier (2008) firm size is an important factor in the determination of total compensation of CEOs. Also, features such as institutional ownership, and hence corporate governance, are also likely affected by firm size (Ferreira and Matos, 2008), making our sample and control groups well-matched.

\section{4. Corporate governance of sample firms}

In Table 6, we examine a number of governance features.

\section{Boards of Directors}

There is disagreement on what constitutes a more effective board. Hermalin and Weisbach (2003) in their survey on research on boards report the following empirical 
regularities: Firms with smaller boards have better performance (Yermack, 1996), but board independence is not related to firm performance. The evidence on CEO/Chairman duality is limited, but again its impact on the firm has been questioned. More recently, Coles, Daniel, and Naveen (2008) have argued that the impact of board size and independence depends on the nature of business of the firm, and that one size does not fit all. As for compensation, Core, Holthausen and Larcker (1999) report higher compensation when board size is large and there are more outside directors. Also CEO pay is higher when the CEO chairs the board (Cyert, Kang, and Kumar, 2002, and Core, Holthausen, and Larcker, 1999). These issues would appear to be moot for our sample firms, however, because none of the board characteristics - size, independence, or duality of chairman and CEO - are reliably significantly different (i.e., mean and median are both significantly different) in Table 6 .

\section{Ownership Structure}

Institutional investors may be considered more sophisticated investors with a superior ability to monitor managers, which may explain the improvements in profitability for firms targeted by institutions (Nesbitt, 1994, and Smith, 1996). Institutions also appear to monitor managers in control-related situations such as takeovers and proxy fights (Brickley, Lease, and Smith, 1988, and Agrawal and Mandelker, 1990). Furthermore, Hartzell and Starks (2003) find that institutional monitoring is associated with lower CEO compensation and higher pay-forperformance sensitivity. Consequently, we examine institutional ownership as a measure of non-CEO shareholder power. ${ }^{16}$

Table 6 shows that sample firms have mean and median institutional ownership of 53\% and $56 \%$, respectively, and that these are statistically significantly different at the $1 \%$ level from the corresponding figures of $61 \%$ and $62 \%$, respectively, for the control group of firms. These findings support the view that non-CEO shareholder power is relatively weak among sample firms.

\footnotetext{
${ }^{16}$ To be sure, the monitoring role of institutions has been questioned in the literature. Some researchers have argued that institutions are myopic, and "vote with their feet."
} 


\section{CEO Ownership}

CEO ownership cuts both ways. Increases in CEO ownership better align interests of the CEO with shareholders, but it also empowers him to exert greater control at a possible expense to other shareholders (Morck, Shleifer, and Vishny, 1988, and McConnell and Servaes, 1990). A CEO with a sizeable stake may be more interested in drawing private benefits of control and in using the firm to expand his perquisite consumption.

Table 6 shows that CEOs of firms adopting \$1 CEO salaries have noticeably higher mean and median stakes in the firm. The figures are $10.09 \%$ and $3.75 \%$, respectively, compared with only $3.21 \%$ and $1.15 \%$, respectively, for the control group. That is, CEOs of adopting firms on average hold more than three times the stake held by CEOs of control firms. It is easy to imagine that CEOs in our sample are more powerful and wield much greater control over their firms compared to other CEOs.

\section{$\underline{\text { Anti-takeover protection measures }}$}

Adoptions of anti-takeover provisions protect CEOs against hostile takeovers and are associated with higher executive compensation (Borokhovich, Brunarski, and Parrino, 1997). Shareholder rights have been proxied with the extent of antitakeover defense provisions. The Investor Responsibility Research Center has published since 1990 details on 24 distinct corporate governance provisions for about 1500 firms. Gompers, Ishii, and Metrick (2003) and Bebchuk, Cohen, and Ferrell (2005) have used this data to develop the G- and E-indexes. We compare these indexes for the sample and control firms, and, as reported in Table 6 , do not find any significant differences.

\section{Compensation Committee}

Given that the $\$ 1$ CEO salary requires the approval of the compensation committee, we examine whether the committee is composed of independent directors and if there is a blockholder present on the committee. Bebchuk, Grinstein and Peyer (2010) find that having a compensation committee that is independent and that includes a blockholder reduces the odds of 
opportunistic timing of executives' option grants. As Table 6 shows, only $34 \%$ of the firms adopting \$1 CEO salaries have an independent committee compared to more than $67 \%$ among the control group (difference is significant at the $1 \%$ level). Few compensation committees have a blockholder present among sample or control firms, though the sample firms seem to have even fewer, $2 \%$ only (difference approaching $10 \%$ level of significance).

Overall, we find relatively weak institutional hold, strong CEO control, and fewer independent committees among firms adopting \$1 CEO salaries, which is a combination that should make CEOs with $\$ 1$ salary relatively more powerful.

\subsection{Total Compensation and its components for sample and control firms}

Next, we examine how the total compensation and its components differ between the sample group of CEOs that work for a dollar-a-year salary and CEOs working at the control group of firms. All dollar amounts are converted to 2005 dollars.

In Table 7, we present the mean and median amounts of income derived by sample and control group CEOs for a number of components of executive compensation. ${ }^{17}$ By design, sample CEOs have lower salary. However, they also have noticeably lower mean (median) bonus, $\$ 161,490$ (\$0) compared to $\$ 673,590(\$ 610,440)$, with the differences being statistically significant at the $1 \%$ level. Consequently, total current cash compensation, which is defined by Compustat as salary plus bonus, is lower by about $\$ 1.2$ million. That is, CEOs who accept to work for a dollar-a-year salary give up a large certain amount in exchange for items that potentially gain from equity-based awards.

Next, we consider Total Compensation, excluding stock and options grants. While CEOs of sample firms receive significantly lower median Total Compensation, there is no difference in mean Total Compensation. But, without grants of options, which are the most important source of income for our sample CEOs, we still cannot judge whether they have lower

\footnotetext{
${ }^{17}$ Relative to the S\&P 500 firms in Frydman and Jenter (2010, Figure 2, Panel B) and in our Table 6, we see that means are much larger than medians, and that there is clear skewness to the right. The options component of total median compensation is much larger among our sample firms (75\%) than for the controls (36\%) or the S\&P 500 sample (36\% in 2004 in their Figure 2 Panel B), reflecting a shift from salary to pay through options.
} 
overall current income, in cash plus securities. So, we turn to the rows for Options Grants and Total Compensation Incl. Option Grants. The mean and median for Option Grants are both greater for the $\$ 1$ CEOs, though only the mean differences are significant. ${ }^{18}$ Risk-averse managers are reasonably expected to seek more in risky options in exchange for what they give up in certain current salary (Hall, 2003). However, the reward seems excessive, with the median value of additional options value for sample firms exceeding that for control by three times the lost amount of salary. Mean differences in values of options are even larger. If the exchange is limited to options for salary, it would appear that the firm gains in terms of taxes. While up to $\$ 1 \mathrm{~m}$. in salary is deductible, there is no limit on deductions on performance-based compensation like stock awards.

Next, we see that CEOs with $\$ 1$ salaries seem to do just as well or better in Total Compensation when we include Option Grants. Total Compensation Incl. Option Grants is greater for $\$ 1$ salary CEOs, whether we look at mean or median, with the mean difference significant at the $10 \%$ level. This would support the view that the loss due to the $\$ 1$ salary is recovered (or even more than recovered) through other compensation. In particular, CEOs with $\$ 1$ salaries give up at the median $\$ 610 \mathrm{~K}$ in salary, but gain more than that with $\$ 2 \mathrm{~m}$. in incremental option awards. Even as attention is focused on the cut in salary, the total compensation of the average CEO seems not to be reduced. But, this inference is based on mean differences without taking into account individual firm characteristics.

Going beyond the univariate analysis, we recognize that total compensation is expected to vary according to the economic attributes of the firm. In particular, CEOs command larger total compensation if firm size, risk, performance, and growth opportunities are larger (Demsetz and Lehn, 1985; Smith and Watts, 1992; Core, Holthausen, and Larcker, 1999; and Cyert, Kang, and Kumar, 2002, Core and Guay, 2002, and Chhaochharia and Grinstein, 2009). Larger, riskier, growth-oriented firms are more complex and require superior managerial talent. Also,

\footnotetext{
${ }^{18}$ For the period of this study, the valuation of option grants came under Accounting Principles Board, Opinion No. 25, Accounting for Stock Issued to Employees, whereby in-the-money warrants were valued at stock price minus exercise price. It is these valuations that were reported, and are used in our analysis. After 2005, under FASB 123, the new standard calculates grant date values using an option pricing model.
} 
CEOs demand more compensation if they have a proven track record of delivering profitability.

Better boards exert better control, while more entrenched CEOs may extract larger compensation. Consequently, we regress the natural log of total compensation on firm size (natural log of firm's assets), risk (standard deviation of firm's daily stock market return over the prior 12-month period or beta riskiness), performance (ROA), board size, and log CEO tenure, lagged Tobin's Q and an indicator variable (which is one for \$1 CEO salary firms and zero otherwise). Regression results are presented in Table 8. We use two definitions of total compensation in the regressions as dependent variables: (1) Total Current Cash Compensation, and (2) Total Compensation Including Options Granted (ExecuComp definition, TDC1). Our variable of interest is the indicator variable that identifies CEOs earning a dollar-a-year salary.

The results clearly show that, on average, the total current cash compensation of $\$ 1$ CEOs is statistically significantly lower than that of their peers. For instance, the total current cash compensation of $\$ 1$ CEOs is, on average, 96\% lower than that of other CEOs. This is of course not a surprise since by design we are comparing firms with no salary and little bonus against other firms.

Adding up stocks and option grants for the total compensation (TDC1), we find that the coefficient of $\$ 1 \mathrm{CEO}$ is not statistically significant anymore. That is, CEOs with $\$ 1$ salaries do not seem to earn a distinguishably different total compensation compared to other CEOs. In the univariate comparison, we reported higher mean total income for CEOs with $\$ 1$ salaries. Overall, we conclude that CEOs with $\$ 1$ salaries appear to make up in stocks and option grants what they gave up in salary and bonus since their total compensation is about the same as that for CEOs of the control group of firms. ${ }^{19}$ This is consistent with the view that the cut in salary by itself gives a misleading idea of the earnings of the CEOs in our sample firms.

Next, we test for our different explanations for why \$1 CEO salaries are adopted.

\footnotetext{
19 Sundaram and Yermack (2007) highlight the importance of another not-so-visible form of compensation, pension. We are able to find detailed information on pension plans for only 18 of our sample firms. When we compare these plans with those in place in the year prior to the adoptions of $\$ 1$ CEO salaries, we discern no obvious changes in plans to ascribe additional income from pension when $\$ 1$ CEO salaries are adopted. There are too few cases of information on severance agreements in the proxy statements to merit a similar general observation.
} 


\section{Testing the Alignment Hypothesis: Factors Motivating Adoptions}

In this section, we focus on a test of the factors that determine which firms will adopt a \$1 CEO salary according to the Alignment Hypothesis. Other predictions of this hypothesis, such as the subsequent value effects of the adoptions of \$1 CEO salaries, are examined separately in later sections.

\section{$\underline{\text { Testable implications }}$}

According to the Alignment Hypothesis, one-dollar CEO salaries are adopted by firms in greater need of alignment of CEO-shareholders interests and/or in possession of more growth options by shifting to a largely stock and options based compensation. First of all, this shift is indeed present among the $\$ 1$ CEOs, as seen in changes for the most comparable group, the 25 incumbent CEOs who changed to $\$ 1$ salaries. ${ }^{20}$ Their proportion of stocks plus options to total compensation, TDC1, went from mean (median) of $48.5 \%(48.1 \%)$ to $70.2 \%(98.8 \%)$, respectively, from the previous year to the first year of $\$ 1$ salary, with the change significant at the $10 \%(5 \%)$ levels in t-test (Wilcoxon z-test). The options component, options to TDC1, saw the following corresponding changes of $43.4 \%$ (30.3\%) to $67.7 \%$ (97.0\%), with the change significant at the 5\% (5\%) level.

From the perspective of greater need for alignment, we predict that firms with $\$ 1$ salary CEOs will be larger, have greater free cash flow, lower leverage, and larger delta values. (Definitions of these measures and others are provided in Appendix B.) The reasons are the following: Jensen and Meckling (1976) argue that larger firms tend to be opaque and are prone to greater managerial agency problems. Firms with greater free cash flow, and less leverage to reduce discretionary free cash flow, are also likely to have more managerial agency problems, according to Jensen (1986). Delta is the dollar change in the CEO's stock and options holdings for a $1 \%$ change in the stock price of the firm (sensitivity of pay to performance). Firms with

\footnotetext{
${ }^{20}$ There were 27 incumbent CEOs who changed to $\$ 1$ salaries, but 2 of them, Robert A. Whitman (Franklin Covey Co.) and Daniel J. Terra (Lawter Intl.) took absolutely nothing $(\mathrm{TDC} 1=0)$ from the firm.
} 
high delta values have recognized in the past a greater need for alignment of CEO-shareholders interests, assuming optimal compensation in the past.

From the perspective of encouraging more risk-taking, we predict that firms with $\$ 1$ CEO salaries will have higher ratios of market-to-book value of assets, greater historic use of options in the CEO compensation package, as well as larger vega values. Many researchers have used market-to-book value of assets to measure growth opportunities (e.g., Bryan, Hwang, and Lilien, 2000; Kole, 1997; Bizjak, Brickley, and Coles, 1993; Graver and Graver, 1993, etc.). Since options increase in value when the underlying assets experience more volatility, they have been used in executive compensation to incent managers to take greater risks (by undertaking growth opportunities). The past use of more options by the firm will therefore be an indicator of the presence of growth opportunities and the need for greater risk-taking incentives. Vega is the dollar change in CEO options holdings for a $1 \%$ change in stock return volatility, which is the sensitivity of the manager's wealth to stock return volatility and captures the extent to which incentives have been used at the firm to help overcome managerial aversion to risk.

\section{Findings}

In Table 9, we present four different specifications testing the Alignment Hypothesis. The findings do not support the view that $\$ 1$ CEO salaries are adopted because there are greater agency problems among these firms or larger growth opportunities, and therefore a need for alignment of interests through extreme measures in the structure of compensation. In untabulated results, we attempt many other combinations of independent variables, but arrive at the same inference. These non-findings are important because they contradict the most frequently reported claim in the proxy statements that $\$ 1$ CEO salaries are adopted to better align the interests of the CEOs with shareholders, along the lines of the optimal contracting approach. 


\section{Testing the Signaling and Managerial Power Hypotheses: Factors Motivating Adoptions}

In this section, we focus on a test of the factors that determine which firms adopt a $\$ 1$ CEO salary according to the Signaling and Managerial Power Hypotheses. Other predictions of these hypotheses, such as the subsequent value effects of the adoptions of \$1 CEO salaries, are examined separately in later sections.

\section{$\underline{\text { Testable implications }}$}

According to the Signaling Hypothesis, one-dollar salaries are adopted by wellgoverned firms to identify credible CEOs who can successfully address the concerns about the firms' prospects. In contrast, the Managerial Power Hypothesis predicts that one-dollar salaries are adopted by firms with weak governance and wealthier CEOs who pursue a personal agenda at a possible cost to shareholders. Some of the predictors of the Signaling Hypothesis for the adoption of $\$ 1 \mathrm{CEO}$ salaries, like the nature of corporate governance, are the same as those for the Managerial Power Hypothesis, though the signs of the effects are the opposite. So, we develop the testable forms of the two hypotheses together.

For governance, we consider various board characteristics (size, independence, duality), ownership structure (CEO and institutional ownership), anti-takeover protection measures (Gand E-indexes), and whether or not the compensation committee is independent.

For concerns regarding the prospects of the firm, we consider recent profitability, using an accounting measure, ROA, and market-based measures, LT abnormal returns, and LT CAR. (The results are similar when Alpha is the performance measure). While the proxy statements generally stress underperformance, we extend our analysis to include cases where the concern is about losing out on growth opportunities. We therefore include Tobin's Q and asset growth as independent variables.

To assess if the CEO belongs among the wealthiest individuals in the US, we consider whether his holdings in the firm place him in the top tercile, and whether or not a CEO is listed among the top 400 richest individuals in Forbes. 
Findings

Table 10 presents probit analyses of the factors that affect the likelihood that a firm will adopt a \$1 CEO salary. Consistent with the univariate comparison, we see that firms with larger CEO ownership are more likely to adopt $\$ 1$ CEO salaries. The coefficient of CEO ownership is positive and statistically significant in all specifications (at the $5 \%$ or better level). The economic magnitude of the coefficient suggests that, ceteris paribus, a one percentage point increase in CEO ownership is associated, on average, with a $0.6 \%$ increase in the probability of being a $\$ 1$ CEO. This is supportive of both the Signaling and Managerial Power Hypotheses. Larger CEO stakes signal greater confidence, but they also imply a stronger CEO. The other ownership factor, however, contradicts the Signaling Hypothesis and supports the Managerial Power Hypothesis. The coefficient of institutional ownership is negative and significant in all specifications (at $5 \%$ level in 3 out of 4 specifications), suggesting that a one percentage point increase in institutional ownership is associated with an average decrease in the probability of being a firm with a $\$ 1 \mathrm{CEO}$ of about $0.25 \%$. Together, these findings on ownership suggest that firms with CEOs with greater shareholder power are more likely to adopt $\$ 1$ salaries, as predicted by the Managerial Power Hypothesis.

The negative significant coefficient (at the $1 \%$ level) on the indicator variable for an independent compensation board is also consistent with the Managerial Power Hypothesis. The Signaling Hypothesis predicts the opposite sign, which would denote better governance.

In every specification, we find that the CEO being among the richest is a significant predictor for the adoption of a $\$ 1$ salary. The coefficient of "Top tercile --Value of CEO shares" is positive and statistically significant (at the $1 \%$ level) in all specifications. The economic magnitude of the coefficient suggests that the richest CEOs are, on average, about $20 \%$ more likely to be $\$ 1$ CEOs.

It should be noted that neither past accounting performance nor stock price performance have significant coefficients, which means that the adoption is not prompted by recent underperformance. 
For further robustness checks, we refer to specification 6 as our base case. In untabulated findings, we find similar results for our base case when the wealth of the CEO is captured through an indicator variable for membership in Forbes' list of the richest individuals. Similarly, repeating the base case with year fixed-effects and clustering the standard errors by industry leads to the same conclusions. These findings are consistent with the Managerial Power Hypothesis because more salary dollars may mean less to them and so there is a greater likelihood that the very richest will want to pursue non-monetary agendas, which is detrimental to other shareholders. Overall, the evidence supports the Managerial Power Hypothesis.

\section{A further test of the Managerial Power Hypothesis: Evidence on CEO overconfidence}

So far we have tested whether $\$ 1 \mathrm{CEO}$ salaries are adopted so as to draw personal benefits. Now, we examine the possibility that the CEO does not necessarily plan to benefit himself at an expense to shareholders. That is, his intentions are not in conflict with the interests of other shareholders. Rather, the CEO accepts the $\$ 1$ salary bet because he is overconfident. That is, as in the Signaling Hypothesis, the CEO is willing to bet that he can successfully carry out his turnaround strategy, but his faith in his ability/strategy may be mistaken in this instance. According to Ben-David, Graham, and Harvey (2007), based on a survey, executives are indeed "miscalibrated," and, "(t)he pervasive effect of this miscalibration suggests that the effect of overconfidence should be explicitly modeled when analyzing corporate decision-making.,"21

\section{Measuring overconfidence}

We examine whether CEOs of firms adopting $\$ 1$ salaries are indeed more overconfident. For this purpose, we follow the media-based procedure described in Malmendier, Tate, and Yan (2010), and Malmendier and Tate (2005) because we do not have access to their "Longholder" data. But, they show that the media-based measure of overconfidence is

${ }^{21}$ CEO overconfidence is not necessarily harmful to shareholders, since overconfident CEOs are associated with greater innovation (Hirshleifer, Low, and Teoh, 2010). However, the greater innovation is in the more innovative industries, while $\$ 1$ CEO salary firms come from a wide variety of industries. 
correlated with their options-based measure. ${ }^{22}$ We follow their procedure with one difference, which is that we employ a wider set of media outlets. Though this increased the collection task considerably, it helped increase coverage of sample and control CEOs.

We read articles from a variety of sources for all our sample and control firms: the main financial press (Wall Street Journal, Financial Times, Business Week, and The Economist), online financial news (PR News Wire and Business Wire), and the regular press (NY Times, Washington Post, Boston Globe, USA Today, The Times, The Guardian, and The Independent). An article is classified as "confident" when it mentions the CEO as using the words "confident", "optimistic", "confidence" or "optimism"; and it is classified as "cautious" when the CEO uses the words "reliable", "practical", "conservative", "frugal", or "steady". We exclude the article from analysis if it was a reprint of an earlier article already included in our analysis. Whenever we find no articles about the CEO, we set the corresponding variable to be zero.

We conduct our media-based analysis twice. Since many of our sample CEOs are firsttime CEOs, we first study them in the year of adoption of $\$ 1$ CEO salaries, making for a CEOs to CEOs comparison with our control group of firms. The findings are reported in Panel A of Table 11. However, the adoption of a $\$ 1$ CEO salary could itself distort media coverage and make sample CEOs appear bolder and overconfident. To avoid that possibility, we also undertake a news analysis for the year prior to the year of adoption of \$1 CEO salaries. The findings for the prior year are reported in Panel B of Table 11.

\section{Comparison of CEO overconfidence}

From a comparison of both mean and median articles per firm for sample versus control CEOs, the sample firms are found to be significantly more "confident." The mean number of "confident" articles is 0.98 for $\$ 1$ CEOs, which is significantly higher than the mean of 0.55 for control group CEOs (the difference is statistically significant at the 5\% level). The medians are 0.5 and zero, respectively, and also statistically significant at the $5 \%$ level. There is no significant difference in the "cautious" articles between the two groups.

\footnotetext{
${ }^{22}$ Moreover, Hayward and Hambrick (1999) find that media praise can cause CEO overconfidence.
} 
For the prior year, the mean for the "confident" articles for the $\$ 1$ CEOs is 0.62 , while the mean for the control group is 0.39 , with the difference being statistically significantly different at the $10 \%$ level. The median is higher for the control firms, 1 versus 0 , but the difference is not statistically significant. However, the mean and median number of articles per firm suggests that the $\$ 1$ CEOs are less cautious than the control group CEOs. The means are 0.04 and 0.2 , respectively, with the difference statistically significant at the $10 \%$ level. The medians are both zero, but still different at again the $10 \%$ level.

Overall, our findings from both analyses in Panel A and Panel B of Table 11 show that \$1 CEOs are relatively overconfident compared to control group CEOs. Thus, this evidence points to an important personal characteristic that distinguishes the \$1 CEO from other CEOs. Overconfidence and the adoption of \$1 CEO salaries

In specification (7) of Table 10, we augment our base case and include our "confident" and "cautious" measures as additional factors that may predict whether the firm will adopt a $\$ 1$ CEO salary. The benefit of this multivariate approach is that other factors that can affect media coverage, like firm size, are now automatically controlled for in our base case. The findings show that the coefficient on "confident" is positive and statistically significant ( $5 \%$ level), which means that firms with overconfident CEOs are more likely to adopt $\$ 1$ CEO salaries. The other independent variables continue to have coefficients with the same signs and significance as before.

\section{The value effects of the adoption of a $\$ 1$ CEO salary}

The predictions of the Alignment and Signaling Hypotheses are the opposite to those of the Managerial Power Hypothesis in terms of the post-adoption performance of firms with $\$ 1$ CEOs. The Alignment and Signaling Hypotheses predict that the adoptions are value-creating, while the Managerial Power Hypothesis predicts that firm value is adversely affected. We test these predictions with an examination of long-term stock returns. ${ }^{23}$

\footnotetext{
${ }^{23}$ To assess the short value effects of adoptions of $\$ 1$ CEO salaries through an event study, we search for announcements of these adoptions and find only 14 such events. Even these 14 events are not "clean"
} 
Studying long-term performance using a measure of LT buy-and-hold abnormal returns creates measurement problems due to overlapping returns of individual firms, as explained by Brav (2000). Nevertheless, in Table 12 Panel A, we examine these buy-and-hold returns, and find that firms with \$1 CEO salaries underperform significantly in the post-adoption period. One way to overcome the problems with buy-and-hold long-term abnormal returns is to use calendar time returns. In Table 12 Panel $\mathrm{B}$, we analyze long-term performance using calendar time returns and estimating a single factor model. We compute monthly returns of two portfolios (sample firms versus control firms) every month ranging from January of the first year post adoption of a $\$ 1 \mathrm{CEO}$ salary to one, or three years later, as indicated in the table. The dependent variable is the equally-weighted monthly return minus the risk-free rate and the independent variable is the CRSP value-weighted return index minus the risk-free rate. To infer whether sample firms underperform control firms in the long run, we estimate regressions on the difference of monthly returns of the two portfolios (sample - controls). A negative and statistically significant alpha indicates that sample firms underperform relative to their peers. In Table 12 Panel B, we look ahead to the one-year and three-year windows. Arguably, one year is too short a window. We find no statistically significant difference there. In three years post the adoption, the firms with $\$ 1$ CEO salaries underperform significantly relative to the control firms. Moreover, the underperformance is economically substantial, to the tune of nearly $1 \%$ per month.

There is reason to believe that the actual long-term returns of sample firms are actually worse than those captured in Table 12 Panel B. The analysis in Table 12 Panel B suffers from survival bias since firms must last all three years for the returns shown in the 3-year window. Later, we see that the delisting rates of our sample firms are significantly greater than those for the control firms.

since they include statements regarding accompanying restructuring, and show an insignificant stock price reaction over the 3-day window surrounding the announcement. We also find insignificant abnormal returns at filing dates for proxy statements for the first year of $\$ 1 \mathrm{CEO}$ salaries. 
To avoid the survival bias, we undertake an alternative analysis to assess the value impact of the \$1 CEO adoptions. Assuming that the market looks ahead and impounds future performance in current firm value, we expect that firms with \$1 CEO salaries will have lower Tobin's Q values at the time of adoptions according to the Managerial Power Hypothesis. This is what we examine in Table 12 Panel C.

The regressions of Tobin's Q (measured as of the fiscal year-end when the CEO starts earning a dollar-a-year salary) show that firms with \$1 CEO salaries have, on average, lower valuations than their peers. For instance, regression (1) of Table 12 Panel $\mathrm{C}$ shows that, holding everything else constant, the average Tobin's Q of sample firms is, on average, 0.81 lower than that of firms in the control group. We follow the literature and include controls for size, profitability, leverage, and growth, along with our variable of interest - the indicator variable for a \$1 CEO - as well as a control for the percentage of shares owned by the CEO and the level of institutional ownership. These findings are also consistent with the Managerial Power Hypothesis.

A Tobin's Q analysis has its own problems, unfortunately. To correct for sample selection bias affecting firms with a dollar-a-year salary CEO, we implement Heckman's (1979) procedure. The first-stage regression (selection equation) is a probit model that estimates the probability of a firm having a $\$ 1$ CEO salary. This is similar to the regressions shown in Table 10 with an additional instrumental variable, "Top tercile - Value of CEO shares". Equation (2) is the second-stage regression, which is identical to equation (1) plus an additional variable, "Lambda", generated from the first-stage regression that attempts to correct for sample-selection bias. The results consistently show that firms with $\$ 1 \mathrm{CEO}$ salaries tend to have lower Tobin's Q, which again conforms with the Managerial Power Hypothesis.

\section{The Potential for Public Outrage}

We have already noted in Table 6 that CEOs with $\$ 1$ salaries hold ownership stakes in their firms that are over three times those held by CEOs working for firms in the control group. Moreover, institutions have smaller holdings in firms with \$1 CEO salaries. The average 
percentage of independents is also relatively low. Arguably, these are just the CEOs who do not have to take a cut in salary. Even if they make it up in the less visible form of equity-based compensation, they are replacing certain income with uncertain income. But, according to the Managerial Power Hypothesis these CEOs are constrained not by the limits of their power against their boards, but by the adverse effects of outrage, such as in a negative story in the Wall Street Journal about stealing from the firm. It is the risk of media coverage and public outrage over the benefits they draw from their firms that leads them to adopt ruses like the $\$ 1$ salary. Consequently, we document whether CEOs of $\$ 1$ salaries have a demonstrable risk of public outrage.

Besides proxy statements, we search Factiva and Lexis-Nexis and read stories about the CEO that make him vulnerable to public outrage, including reports that cover the following: prior media interest in his compensation and other benefits, like use of company airplane; shareholder resolutions; pending government inquiries about the firm or executives; underperformance or slowdown at the firm; recent interest in his pay; cost-cutting, pay cuts or layoffs at his firm; personal matters such as divorce proceeding that may expose his wealth; chairman took a \$1 salary; and, about his significant holdings and voting power, etc. In Table 13, we list these for the 25 cases where we found explicit stories. In addition, it should be noted that whenever a CEO holds a significant fraction of the stock of a firm, there is a presumption of power at the firm and of the drawing of undeserved benefits. If we use $5 \%$ holdings of the stock, there are 23 such cases among our \$1 CEOs. Not double-counting the 9 cases overlapping between CEOs in Table 13 and those that hold more than 5\% of their firm's stock, we have a total of 39 CEOs or $78 \%$ of our sample at risk of public outrage. It is not surprising that this group has chosen to adopt $\$ 1$ salaries as camouflage for their benefits.

In Table 13, we also look ahead and search for the potential causes for outrage in the year following the last year of a $\$ 1$ CEO salary. In particular, we check if the potential for outrage, which is documented from the time of adoption, is continuing or has subsided. In addition, we search for new factors that might make a case for keeping the $\$ 1$ salary arrangements. Except for a few cases, there is clear evidence in the right-hand column of Table 
13 that the potential for outrage is lower, consistent with dropping the $\$ 1$ CEO salary. In some cases, the performance of the firm is better. In others, reorganizations, like mergers or completion of restructuring, have occurred. In yet others, personal situations have changed.

\section{Additional analyses and discussion}

We undertake a number of robustness checks in this section, besides examining additional perspectives regarding \$1 CEO salaries.

\section{Alternative Controls: All other firms on ExecuComp}

To ensure that our findings are not driven by our choice of controls, we repeat our analysis without exercising discretion in the selection of controls, taking all non-sample firms as controls. To be sure, this is not a preferred methodology. Given that many of our sample firms are large, this procedure will allow for many small firms to be a part of the control group. Moreover, this is too large a sample to hand-collect all the variables employed in our base case.

The probit analysis with unmatched controls is shown in Table 14 Panel A. The basic findings from our earlier analysis continue to hold. As before, firms with \$1 CEO salaries have CEOs with larger ownership stakes in their firms (1\% or $5 \%$ level of significance), and institutional holdings are lower (10\% level). But, we also see several board differences between sample and control firms. Further suggesting weak governance, we see that sample firms have lower proportion of independent directors (mostly $1 \%$ level), and an absence of blockholders on the compensation committee ( $1 \%$ level). The one contrary finding is that sample firms are expected to have smaller boards, which is arguably an indicator of better boards.

There is one troubling finding in Table 14 Panel A. We see that larger firms are expected to adopt $\$ 1$ CEO salaries. This is likely the result of too many unmatched small firms entering the control group.

In Table 14 Panel $\mathrm{B}$, we examine the long-term performance in the post-adoption period. We see that the here again, the sample firms underperform. The average monthly returns are $-0.9 \%$ less for sample firms for the 3-year window, which are substantially poorer returns. 
Alternative post-adoption performance measures: bankruptcies, delistings, and CEO turnover

In Table 15, we find that $40 \%$ of the firms have disappeared within 3 years, which is consistent with the poor post-adoption performance we have documented so far. There are more bankruptcies according to UCLA's LoPucki Bankruptcy Database and Chapter11Library.com. There are also significantly more delistings. These findings are consistent with the poor postadoption performance we have reported above.

Only $48 \%$ of our sample CEOs continue as CEOs with their firms after the last year of a \$1 CEO salary, which is on average 3.16 years. Jenter and Kanaan (2008) report a total turnover (voluntary and forced) among Ехеси Сотр CEOs of only 9.14\% for an overlapping period, 1993-2001. Other studies, Weisbach (1988) and Kaplan and Minton (2010) also show low rates of CEO turnover in the general population. The rate of CEO turnover (52\% over 3 years) is much larger for $\$ 1$ CEOs, even if we correct for the disappearance of the firms themselves (22\% delistings in 3 years).

In another examination of the post-adoption period, in Figure 1 we plot the ROA for the sample and control groups of firms. The differences are not statistically significant. The ROAs follow a similar pattern, except the firms with $\$ 1$ CEO salaries seem to deteriorate as we go to years $t+2$ and $t+3$.

\section{Restructuring: What do the CEOs do after the adoption of a $\$ 1$ CEO salary?}

We approach this issue from two perspectives, examining in each case the capital expenditures of the firm. Though not the only form, we expect the 3-year changes in capital expenditures to be a likely indicator of restructuring undertaken by the CEO. As noted in Table 5, firms adopting \$1 CEO salaries have a larger change in capital expenditures from the year prior to the adoption of a $\$ 1$ CEO salary to two years after it, capex $(-1,+2)$. Compared to nonadopting control firms, Table 5 shows that sample firms have a higher mean and median capex $(-1,+2)$, though only the mean difference is statistically significant $(5 \%$ level $)$. This is suggestive of restructuring activity. 
In an alternative view, if we consider the actual capex $(-1,+2)$ as the best forecast of the capital expenditures that the $\$ 1$ salary CEO is proposing, a variable that reflects his turnaround plan. In that case, the capex $(-1,+2)$ is factored into the likelihood that the CEO will win approval. Indeed, in Specification (2) in Table 10, we see that capex $(-1,+2)$ is a significant predictor of the adoption of a $\$ 1$ CEO salary.

\section{$\underline{\text { Subsamples }}$}

In an attempt to identify differences in groups, we examine (a) CEOs who earn $\$ 1$ salaries for just a year versus others. The idea is that those with a short-term horizon may be facing some immediate challenge, compared to a long-term problem. We also compare (b) CEOs with the long-term performance, Alpha, positive in the previous 3 years versus others. We consider (c) if the appointment is internal versus external. And, (d) we compare first-time CEOs against the rest. In each case, we compare their Alphas in the 3 years following the adoption of a $\$ 1$ CEO salary, using the calendar time approach. None of the difference turn out to be statistically significant, probably because the subsamples are too small or that these particular aspects are not crucial differences.

\section{Conclusion}

We study the motives and impact of \$1 CEO salaries. Our sample consists of 50 CEOs of U. S. publicly listed firms over the years, 1992-2005. While the arrangement is not common, the firms adopting it appear to be quite ordinary in many ways. Compared to other firms in the control group in the years of their adoptions of \$1 CEO salary, they have similar average size, growth, and riskiness. On average, their stock has also not underperformed. Even the CEOs accepting \$1 salaries are similar in age and education to CEOs of other firms. They are also not overrepresented by founders or comeback CEOs stepping up to rescue their legacies. If anything, they have a significantly shorter past association with the firm compared to the control group of CEOs. Why then do these firms and their CEOs, and not so many others, adopt $\$ 1$ 
CEO salaries, and what is the resulting impact on their firms? Prior research has not addressed these questions.

In this paper, we empirically examine a number of hypotheses to explain why some CEOs work for a $\$ 1$ salary. It has been asserted that the $\$ 1$ salary is a facade behind which CEOs collect large not-so-visible forms of compensation. Indeed, we find that $\$ 1 \mathrm{CEOs}$ do not lose out in terms of total compensation. They make up through stocks and options what they give up in salary. We also rule out the most frequent claim made in proxy statements that such a drastic cut in salary is meant to shift incentives towards equity-based payoffs in order to better align CEO-shareholders interests (or to incent the CEO to take greater risks). We do not find that the likelihood of adoption of \$1 CEO salary is greater for firms with more managerial agency problems or greater growth potential. Thus, adoptions of one-dollar CEO salaries appear to be motivated by other considerations than obtaining the optimal compensation structure.

We propose two other alternative hypotheses, a Signaling Hypothesis and a Managerial Power Hypothesis, to explain the phenomenon. According to the Signaling Hypothesis, the CEO credibly signals his ability by betting his current income in exchange for a larger payoff later. We find that, as predicted, \$1 CEOs have relatively larger equity stakes compared with CEOs at firms in the control group, and this reinforces the notion that they have "skin in the game." We expect only capable CEOs to agree to this bargain, just as we expect boards to sign off only if they believe that the candidate is deserving. As a result, we expect the compact to be value-creating. The Signaling Hypothesis fails this crucial test. Firms with one-dollar CEO salaries have lower long-term returns in the post-adoption period, and higher rates of delistings. Markets seem to anticipate their underperformance since the Tobin's Q for firms with \$1 CEO salaries is lower.

Finally, we examine the Managerial Power Hypothesis, which states that the \$1 CEO salary is a camouflage that allows the CEO to pursue a self-serving personal agenda. According to this hypothesis, powerful CEOs adopt $\$ 1$ salaries to prevent outrage over their total compensation. This hypothesis is supported by the data, since the total compensation of CEOs with $\$ 1$ salaries is similar to that of CEOs at control firms. Also consistent with this hypothesis, 
the CEO wields greater shareholder power at firms with $\$ 1 \mathrm{CEO}$ salaries, since we find that their equity stakes are larger at these firms while the institutional holdings are comparatively low. Such powerful CEOs need not take a cut in salary, except as a ruse to deflect attention from their actual benefits from the firm. There are also behavioral reasons that suggest that the CEO may be pursuing a self-serving agenda at firms with $\$ 1$ CEO salaries. We find that CEOs at firms with \$1 CEO salaries are more overconfident individuals, and consequently may be placing greater faith than deserved on their strategies for their firms. We also find them to be richer than CEOs at control firms, which can lead them to value non-monetary objectives more. As predicted, firms underperform following the adoptions of \$1 CEO salaries. Overall, the evidence is supportive of the Managerial Power Hypothesis, which claims that compensation structures are a mechanism in the hands of powerful CEOs, not to set optimal incentives, but as a tool to extract rents. 


\section{References}

Agrawal, Anup, and Gershon N. Mandelker, 1990, "Large Shareholders and the Monitoring of Managers: The Case of Antitakeover Charter Amendments," Journal of Financial and Quantitative Analysis 25, 143-161.

Baysinger, B. and H. Butler, 1985, "Corporate Governance and the Board of Directors: Performance Effects in Board Composition," Journal of Law, Economics and Organization 1, 101-124.

Bebchuk, Lucian A., A. Cohen, and A. Ferrell, 2005, "What Matters in Corporate Governance?" Harvard Law School Working Paper.

Bebchuk, Lucian A., Jesse M. Fried, and David Walker, 2002, "Managerial Power and Rent Extraction in the Design of Executive Compensation," University of Chicago Law Review 69, 751-846.

Bebchuk, Lucian A. and Jesse M. Fried, 2003, "Executive Compensation as a Agency Problem," Journal of Economic Perspectives 17 (3), 71-92.

Bebchuk, Lucian A. and Jesse M. Fried, 2004. Pay without Performance: The Unfulfilled Promise of Executive Compensation, Harvard University Press, Cambridge, MA.

Bebchuk, Lucian A., Yaniv Grinstein and Urs Peyer (2010), "Lucky CEOs and Lucky Directors," Journal of Finance 65, 2363-2401.

Ben-David, Itzhak, John R. Graham, and Campbell Harvey, 2007. "Managerial overconfidence and corporate policies," Duke University Working Paper.

Bebchuk, Lucian A., Martijn Cremers, and Urs Peyer, 2006. "Pay distribution in the top executive team," Discussion Paper No. 574, Harvard Law School, Cambridge, MA.

Bertrand, M., 2005. "CEOs," University of Chicago Working Paper.

Bertrand, M. and A. Schoar, 2003. "Managing with style: the effect of managers on firm policies," Quarterly Journal of Economics 18 (4), 1169-1208.

Bertrand, M., and S. Mullainathan, 2003, "Enjoying the Quiet Life? Corporate Governance and Managerial Preferences," Journal of Political Economy 111 (5), 1043-1075.

Bhide, Amar, 1994, "Efficient Markets, Deficient Governance: U.S. Securities Regulations Protect Investors and Enhance Market Liquidity. But do they Alienate Managers and Shareholders?” Harvard Business Review 72, 128-140.

Bizjak, J. M., J. A. Brickley, and J. L. Coles, 1993. "Stock-based incentive compensation and investment behavior," Journal of Accounting and Economics 16, 349 - 372.

Black, Bernard S., 1990, "Shareholder Passivity Reexamined," Michigan Law Review 89, 520608.

Black, Bernard S., and John Coffee, 1994, "Hail Britannia?: Institutional Investor Behavior Under Limited Regulation," Michigan Law Review 92, 1999-2088.

Borokhovich, Kenneth A., Kelly R. Brunarski and Robert Parrino, 1997, "CEO Contracting and Anti-Takeover Amendments," Journal of Finance 52 (4), 1495-1517.

Brav, A., 2000. "Inference in long-horizon event studies: A Bayesian approach with applications to initial public offerings." Journal of Finance 55: 1979-2016.

Brickley, James A., Ronald C. Lease, and Clifford W. Smith, 1988, "Ownership Structure and Voting on Antitakeover Amendments," Journal of Financial Economics 20, 267-293.

Brickley, James A., Jeffrey L. Coles, and Rory L. Terry, 1994, "Outside Directors and the Adoption of Poison Pills," Journal of Financial Economics 35, 371-390.

Bryan, S., L. Hwang, and S. Lilien, 2000. "CEO stock-based compensation: An empirical analysis of incentive-intensity, relative mix, and economic determinants," Journal of Business 73(4), 661-693..

Bryd, J. and K. Hickman, 1992, "Do Outside Directors Monitor Managers? Evidence from Tender Offer Bids," Journal of Financial Economics 32, 371-390.

Chhaochharia, Vidhi, and Yaniv Grinstein, 2009, "CEO Compensation and Board Structure," Journal of Finance 64, 231-261.

Coles, Jeffrey L., Naveen D. Daniel, and Lalitha Naveen, 2008, “Boards: Does one size fit all?", Journal of Financial Economics 2, 329-356. 
Core, John E., Wayne R. Guay, and Randall S. Thomas, 2005, "Is U.S. CEO Compensation Inefficient Pay without Performance?" Working Paper, University of Pennyslvania.

Core, John E. and Jun Qian, 2001. "Option-like contracts for innovation and production," Boston College Working Paper.

Core, John E., and Wayne R. Guay, 2002, "Estimating the Value of employees Stock Option Portfolios and their Sensitivities to Price and Volatility," Journal of Accounting research 40, 613-630.

Core, John E., Wayne R. Guay, and David F. Larcker, 2003, "Executive equity compensation: A survey," Federal Reserve Bank of New York Economic Policy Review 9, 27-50.

Core, John E., Robert W. Holthausen, and David F. Larcker. 1999, "Corporate governance, chief executive officer compensation, and firm performance," Journal of Financial Economics 51, 371-406.

Cotter, J., A. Shivdasni, and M. Zenner, 1997, "Do Independent Directors Enhance Target Shareholders Wealth during Tender Offers?" Journal of Financial Economics 43, 195218.

Cremers, Martijn, and Darius Palia, 2010, "Tenure and CEO Pay," Working Paper, Yale University and Rutgers Business School.

Cronqvist, H., Makhija, A., and S. Yonker (2011). "Behavioral consistency in corporate finance: CEO personal and corporate leverage," Journal of Financial Economics, forthcoming.

Cyert, R., S. Kang, and P. Kumar, 2002, "Corporate governance, takeovers and top-management compensation: Theory and evidence," Management Science 48, 453-469.

DeCarlo, Scott, 2007, "Big paychecks," Forbes.Com, May 3. http://www.forbes.com/2007/05/03/ceo-executive-compensation-lead-07ceocx_sd_0503ceocompensationintro.html

Demsetz, Harold and Ken Lehn, 1985, "The structure of corporate ownership, causes, and consequences," Journal of Political Economy 93, 1155-1177.

Edmans, Alex, and Xavier Gabaix, 2009, "Is CEO Pay Really Inefficient? A Survey of New Optimal Contracting Theories," European Financial Management 15, 486-496.

Ferreira, Miguel A., and Pedro Matos, "The Colors of Investors' Money: The Role of Institutional Investors Around the World," Journal of Financial Economics 88 (3), 499-533.

Frydman, Carola and Dirk Jenter, 2010, "CEO Compensation," Rock Center of Corporate Governance, Stanford University Working Paper No. 77.

Frydman, Carola and Raven E. Sachs, 2008, "Executive Compensation: A New View from a Long-term Perspective, 1936-2005," National Bureau of Economic Research Working Paper 14145.

Gabaix, Xavier, and Augustin Landier, 2008, "Why Has CEO Pay Increased So Much?" Quarterly Journal of Economics 123, 49-100.

Gaither, Chris, 2006, "Google execs make a lot less than you," Global Technology Forum, Economist Intelligence Unit, The Economist, April 20. http://globaltechforum.eiu.com/index.asp?layout=rich_story\&doc_id=8476\&categoryid $=\&$ channelid=\&search $=$ outrage

Gaver, J., and K. Gaver, 1993, "Additional evidence on the association between the investment opportunity set and corporate financing, dividend, and compensation policies," Journal of Accounting and Economics 16, 125 - 160.

Gompers, Paul A., Joy Ishii, and Andrew Metrick, 2003, "Corporate Governance and Equity Prices," Quarterly Journal of Economics 118, 107-155.

Graham, J. R., C. R. Harvey, and M. Puri, 2009, "Managerial attitudes and corporate actions," Working Paper, Fuqua School of Business, Duke University.

Graham, J. and K. Narasimhan, 2004, "Corporate Survival and Managerial Experiences During the Great Depression," Working Paper, Duke University.

Gray, Steven, 2006, "Natural Competitor: How Whole Foods CEO Mackey intends to stop growth slippage; Leadership on salary of $\$ 1$ a year," Wall Street Journal, Dec. 4., Section B, 1-3.

Guay, W. R., 1999. "The sensitivity of CEO wealth to equity risk: An analysis of the magnitude and determinants," Journal of Financial Economics 53, 43-71. 
Guthrie, Katherine, Jan Sokolowsky, and Kam-Ming Wan, 2010, "CEO Compensation and Board Structure Revisited," Forthcoming Journal of Finance.

Hayward, Matthew L. A., and Donald C. H. Hambrick, 1997, "Explaining the Premium Paid for Large Acquisitions: Evidence of CEO Hubris," Administrative Science 42, 103 -.

Hirshleifer, David A., Angie Low, and Siew Hong Teoh, 2010. "Are overconfident CEOs better innovators?" University of Irvine Working Paper.

Hall, Brain J., 2003. "Six challenges in designing equity-based pay," Journal of Applied Corporate Finance 15 (3), 21-33.

Hart, Oliver and Bengt Holmstrom, 1987, "The Theory of Contracts," in T. Bewley, ed., Advances in Economic Theory, Fifth World Congress, Cambridge, Cambridge University Press.

Hartzell, Jay C. and Laura T. Starks, 2003, "Institutional Investors and Executive Compensation," Journal of Finance 58, 2351-2374.

Heckman, J., 1979), "Sample selection bias as a specification error," Econometrica 47, 153-161.

Herbst, Moira, 2007, "The Elite Circle of \$1 CEOs," Business Week, May 10. http://www.businessweek.com/managing/content/sep2007/ca20070914_637253.htm?ca mpaign id=rss null

Hermalin, E. Benjamin and Michael S. Weisbach, 2003, "Board of Directors as an Endogenously Determined Institution: A Survey of the Economic Literature," Economic Policy Review 9, 7-26.

Jensen, M. C., 1986. "Agency costs of free cash flow, corporate finance, and takeovers," American Economic Review 76, 323 - 329.

Jensen, Michael C., 1993, "The Modern Industrial Revolution, Exit, and the Failure of Internal Control Systems," Journal of Finance 48, 831-880.

Jensen, M. C. and W. Meckling, 1976, "Theory of the firm: Managerial behavior, agency costs, and ownership structure," Journal of Financial Economics 3, 305- 360.

Jensen, M. C. and K. J. Murphy, 1990, "Performance pay and top management incentives," Journal of Political Economy 98, 225 - 264.

Jenter, Dirk, and Fadi Kanaan, 2008, "CEO Turnover and Relative Performance Evaluation," Working Paper, Stanford University.

Johnson, Marilyn F., Susan Porter, and Margaret B. Shackell, 1997. "Stakeholder Pressure and the Structure of Compensation," Michigan State University Working Paper.

Kaplan, S. N., M. M. Klebanov, and M. Soresen, 2008, "Which CEO characteristics and abilities matter?" Working Paper, Booth School of Business, University of Chicago.

Kaplan, Steven N. and Bernadette A. Minton, 2010. How has CEO Turnover Changed? Dice Center Working Paper, Fisher College of Business, The Ohio State University.

Khurana, R., 2002. Searching for a Corporate Savior: The Irrational Quest for Charismatic CEOs, Princeton: NJ: Princeton University Press.

Kole, S. 1997, "The complexity of compensation contracts," Journal of Financial Economics 43, 79 - 104.

Karpoff, Jonathan M., Paul H. Malatesta, and Ralph A. Walkling, 1996, "Corporate Governance and Shareholder Initiatives: Empirical Evidence," Journal of Financial Economics 42, 365-395.

Leland, H. E., and D. H. Pyle, 1977, "Informational Asymmetries, Financial Structure, and Financial Intermediation," Journal of Finance 32, 371-387.

Malmendier, U. and G. A. Tate, 2005, "CEO overconfidence and corporate investment," Journal of Finance 60, 2660-2700.

Malmendier, U. and G. A. Tate, 2009, "Superstar CEOs," Quarterly Journal of Economics 124, 1593-1638.

Malmendier, U., G. A. Tate, and J. Yan, 2010, "Overconfidence and Early-life Experiences: The Effect of Managerial Traits on Corporate Financial Policies," Journal of Finance, forthcoming.

Maug, E., 1998, "Large Shareholders as Monitors: Is there a Tradeoff Between Liquidity and Control?" Journal of Finance 53, 65-98.

Mayerowitz, Scott, 2008, “The other side of the \$1 salary," ABC News, Business Unit, Dec. 3. 
http://abcnews.go.com/Business/Economy/Story?id=6378775\&page=1

McConnell, J., and H. Servaes, 1990, "Additional Evidence on Equity Ownership and Corporate Value," Journal of Financial Economics 27, 595-618.

Michalisin, Michael D., Douglas M. Kline, and R. D. Smith, 2000. "Intangible Strategic Assets and Firm Performance: A Multi-Industry Study of the Resource-based View," Journal of Business Studies 17, 93 -117.

Milgrom, Paul and John Roberts, 1982. "Predation, Reputation and Entry Deterrence," Journal of Economic Theory 27, $280-312$.

Morck, R., A. Shleifer, and R. W. Vishny, 1988, "Management Ownership and Market Valuation: An Empirical Analysis," Journal of Financial Economics 20, 293-315.

Murphy, Kevin J., 1999, “Executive compensation,” in Ashenfelter, O. and D. Card, eds.: Handbook of Labor Economics, Vol. 3, North-Holland, Amsterdam.

Myers, Stewart C., 2000, “Outside Equity,” Journal of Finance 55 (3), 1005-1037.

Nesbitt, Stephen, 1994, "Long-term Rewards from Shareholders Activism: A Study of the CalPERS Effect," Journal of Applied Corporate Finance 6, 75-80.

Noe, T., 2002, "Institutional Activism and Financial Market Structure," Review of Financial Studies 15, 289-319.

Pound, John, 1988, "Proxy Contests and the Efficiency of Shareholder Oversight," Journal of Financial Economics 20, 237-265.

Roberts, Peter, and Grahame Dowling, 2002. "Corporate Reputation and Sustained Superior Financial Performance,” Strategic Management Journal 23, 1077-1093.

Roe, Mark J., 1994, Strong Managers, Weak Owners: The Political Roots of American Corporate Finance, Princeton University Press, Princeton, NJ.

Scheier, M. F., C. S. Carver, and M. W. Bridges, 1994, "Distinguishing optimism from neuroticism (and trait anxiety, self-mastery, and self-esteem): A re-evaluation of the Life Reorientation Test," Journal of Personality and Social Psychology 67, 1063-1078.

Schoar, A., 2007, "CEO careers and style," MBER Working Paper.

Shleifer, Andrei and Robert W. Vishny, 1986, "Large Shareholders and Corporate Control," Journal of Political Economy 94, 461-488.

Smith, Michael, 1996, "Shareholder Activism by Institutional Investors: Evidence from CalPERS," Journal of Finance 51, 227-252.

Smith, Clifford W. and R. L. Watts, 1992, "The investment opportunity set and corporate financing, dividend, and financing policies," Journal of Financial Economics 32, 262 292.

Song, Moon H. and Ralph A. Walkling, 1993, "The Impact of Managerial Ownership on Acquisition Attempts and Target Shareholder Wealth," Journal of Financial and Quantitative Analysis 28, 439-457.

Thomas, Randall S. and Kenneth J. Martin, 1999. "The effect of Shareholder Proposals on Executive Compensation," University of Cincinnati Law Review 67 (4), 1021-1081.

Sundaram, R. K. and David Yermack, 2007. "Pay me later: inside debt and its role in managerial compensation," Journal of Finance 62 (4), 1551-1588.

Weisbach, Michael S., 1988, "Outside Directors and CEO Turnover," Journal of Financial Economics 20, 431-460.

Weisbach, Michael S., 2007, "Optimal Executive Compensation versus Managerial Power: A Review of Lucian Bebchuk and Jesse Fried's Pay without Performance: The Unfulfilled Promise of Executive Compensation," Journal of Economic Literature 45, 419-428.

Yermack, David, 1996. "Higher market valuation of companies with a small board of directors," Journal of Financial Economics 40, 185 -211.

Yankowski, Carl, 2006, “CEO \$1 Club,” interviewed by Kai Ryssdal in Marketplace, July 18. http://marketplace.publicradio.org/display/web/2006/07/18/ceo_1 club/ 


\section{APPENDIX A: REASONS FOR A \$1 SALARY IN PROXY STATEMENTS (Form DEF 14a)}

1992 Panenergy Corp

\section{Dennis R.}

Hendrix

1993 Lawter Daniel J.

International Inc Terra

1993 Grand Casinos

Wendy's/Arby's

1994 Group Inc

(formerly

Triarc)

1995 Epicor Softwar Corp

1996 El Paso Corp

1996 Masco Corp

1996 Autonation Inc

1996 L A Gear Inc

Lyle

Berman

Carmelo J. Santoro
In November 1990, Mr. Hendrix and the Company entered into an agreement whereby he would receive no salary for 1991, 1992, and 1993. Instead, Mr. Hendrix was awarded 300,000 shares of restricted Common Stock under the terms of the 1990 LTIP as compensation for that period...Effective February 24, 1993, the agreement with Mr. Hendrix was amended to extend the term through November 1996 and to award him an additional 300,000 shares of restricted Common Stock in lieu of salary for the period November 1993 through November 1996

Mr. Terra has been authorized to receive but has waived his annual salary from the Company since 1982. In addition, Mr. Terra does not receive grants of stock options under the Company's stock option plan.

Prior to July 31, 1994, Messrs. Berman and Taube received benefits and in lieu of salary were compensated under the Company's Incentive Plan.

Nelson Peltz Peltz gave up his cash salary in return for payout in options for the following years

Dr. Santoro became Acting Chief Executive Officer of the Company on April 17, 1994 and Chief Executive Officer in May 1994. Dr. Santoro received a director fee for service on the Board in lieu of salary. Dr. Santoro resigned as Chief Executive Officer in February 1996, when Mr. Klaus joined the Company.

Mr. Wise's base salary was eliminated and replaced with long-term awards of stock options and restricted stock, the majority of which vest only after the expiration of specified time periods and only if certain performance targets are met within those periods. This change is consistent with Company-wide cost reduction initiatives and is intended to align Mr. Wise's compensation more directly with stockholder value.

Mr. Manoogian's salary and bonus were reduced at his request, effective January 1, 1996, to $\$ 1$ per year. Mr. Manoogian requested the Compensation Committee Richard A. of the Board of Directors to implement this reduction to reflect his commitment to enhance stockholder value and his personal disappointment with the Company's Manoogian stock price performance in recent years

Mr. Huizenga is not paid any cash salary or bonus...Compensation Committee believes that tying the remuneration of Messrs. Huizenga and Berrard to the H. Wayne performance of Republic's Common Stock will enhance the long-term performance and stability of Republic by providing Messrs. Huizenga and Berrard the Huizenga incentive to expand the Company's businesses and bring Republic to increased levels of profitability in future years...provides an incentive to each of them to maximize shareholder value...

Stanley P. At Mr. Gold's request, he did not receive any salary or other cash compensation during fiscal 1996 for his services as Chief Executive Officer of the Company 
CBS Corp

1996 (formerly Viacom)

1997 Intl Game Technology Fruit Of The

1997 Loom Ltd -C A

997 Borders Group

Netscape

1997 Communications James L. Corp Barksdale

1997 Gulfstrean Aerospace

997 Checkers Drive- C. Thomas In Restaurant

1998 Apple Inc

1998 Macdermid Inc

1998 Metaldyne Corp

Hennessey

1998 Pepsico Inc Redstone

illiam F.

Robert F.

Steven P.

Jobs

Daniel $\mathrm{H}$

Leever
Mr. Redstone has waived payment of any salary or bonus compensation for his services as Chief Executive Officer of the Company. A special grant under the 1994 LTMIP of stock options to purchase 1,000,000 shares of Class B Common Stock was awarded to Mr. Redstone in January 1996 to reflect his assumption of additional responsibilities as Chief Executive Officer.

Charles N. As Chief Executive Officer, he receives no base salary. The Committee, based on its subjective evaluation of Mr. Mathewson's performance, granted Mr Mathewson Mathewson stock options in February 1996 to acquire 1,000,000 shares of the Company's Common Stock.

Mr. Farley elected to forego \$950,000 of his salary in 1997, 1998 and 1999 in consideration of the grant of options under the terms of the Executive Equity Investment Program.

(in 1997/1998/1999) Messrs. DiRomualdo, Mrkonic,... were granted options in lieu of cash payment for 100\% of their salary and bonus...FYR 1996, Mr.

DiRomualdo, $\$ 515,000$ salary, $\$ 525,300$ bonus (100\% of bonus used for the purchase of restricted shares);...FYR 1995, Mr. DiRomualdo, Mr. Mrkonic, Mr.

Quinnell and Mr. Flanagan elected to forego the payment in cash of all of their 1995 salary earned subsequent to the Company's initial public offering and a

portion of their 1996 salary and all of their "on plan" bonus for fiscal 1995 (the maximum portion of the bonus as to which an election was available) and to apply such amounts toward the purchase of restricted shares... Mr. Pfeffer was granted options in lieu of cash for $100 \%$ of his compensation.

For 1997, Mr. Barksdale elected to receive a salary of $\$ 1.00$ and to return an option grant of 300,000 shares made in April 1997. Mr. Barksdale believes that his compensation should be linked to the long-term interests of Netscape's stockholders. Accordingly, through his ownership position in Netscape's Common Stock, Mr. Barksdale's pecuniary interests are aligned with those of Netscape's stockholders. For the same reasons, Mr. Barksdale has elected to receive a salary of $\$ 1.00$ for 1998

Thoedore J. The Company does not have a chief executive officer, but has a five-person Management Committee chaired by Mr. Theodore J. Forstmann, who receives no cash compensation for his services to the Company, and including W.W. Boisture, Jr., Chris A. Davis, James T. Johnson and Bryan T. Moss.

C. Thomas Thompson served as Chief Executive Officer from December 17, 1996 to November 9, 1997 and received no compensation for his duties as an officer of the ompany during fiscal year 1997, except for stock options granted to Mr. Thompson in fiscal year 1997 as reported in the table set forth under "Option Grant in Last Fiscal Year."

The Compensation Committee recognizes that Mr. Jobs' level of stock ownership significantly aligns his interests with those of the Company's shareholders

Under the terms of the plan, no base salary was paid to Mr. Leever

The annual salary and bonus of the Company's Chairman, Richard A.Manoogian, of $\$ 573,000$, was reduced at his request, effective January 1 , 1998 , to $\$ 1$ per year. Frank M. Hennessey, who became the Company's Vice Chairman and CEO in early 1998, also requested that he receive annual salary and bonus of $\$ 1$ for 1998. The Compensation Committee believes that replacing all of the cash compensation ... with compensation that is tied to the value of Company Common Stock over an extended period of time firmly links the interests of the Company's leaders with those of stockholders... Messrs. Manoogian and Hennessey first requested in 1998 that their salary and bonus be reduced to $\$ 1$ to demonstrate their commitment to enhance stockholder value and their disappointment with the Company's recent stock price performance...

At Mr. Enrico's request, the Committee approved a reduction in Mr. Enrico's annual salary from $\$ 900,000$ to $\$ 1$, and recommended to the Board of Directors that Roger A. it consider using the savings to support front line employees(scholarship for children of PepsiCo's sales people, truck drivers, manufacturing plant workers and Enrico other front line employees). In January 1999/2000, the Board approved annual charitable contributions of approximately $\$ 1,000,000$ to fund additional scholarships for children of PepsiCo's front line employees. 
1998 Capital One Financial Corp

Richard D

Fairbank

Univision

998 Communications A. Jerrold Inc

999 Leggett \& Platt

1999 ZIX Corp

1999 AES Corp

\section{Cameron}

International

1999 Corp (formerly

Cooper

Cameron

Corporation)

1999 MarchFirst Inc

1999 Agribrands International Inc Stiritz

Wright Cook Bakke Erikson

Robert F.
Under a compensation package approved by the Board of Directors on December 18, 1997 (EntrepreneurGrant II), Messrs. Fairbank and Morris agreed to give up their entire salary and all benefits under the Stock Purchase Plan, the Savings Plan and the company's Unfunded Excess Savings Plan (the "Excess Savings Plan") through 2000 in exchange for an award of performance-based options...Under a compensation package approved by the Board of Directors on December 20,2004, Mr. Fairbank agreed to give up his entire salary and all benefits ...From 1997 through 2008, the compensation structure for the CEO consisted entirely of equity awards (typically stock options) in lieu of any salary, bonus, retirement plan contributions or other traditional forms of compensation. Compensating the CEO in stock options, in lieu of cash compensation, provides a strong alignment between the CEO's financial rewards and the value he delivers to stockholders.

Mr. Perenchio serves as CEO without remuneration...A. Jerrold Perenchio and his affiliates beneficially own 100\% of the Class P Common Stock, Televisa beneficially owns $100 \%$ of the Class T Common Stock, and Venevision beneficially owns $100 \%$ of the Class V Common Stock. Mr. Perenchio, Univision's Chairman and Chief Executive Officer, serves without salary, bonus or equity-based compensation. As a significant stockholder and holder of majority voting power, Mr. Perenchio remains highly motivated to increase Univision's stockholder value and to incentivize management to do the same.

Includes stock options for 52,118 shares awarded Mr. Wright in lieu of \$709,084 of 1999 bonus and 50,294 shares awarded in lieu of $\$ 658,614$ of 1999 salary and certain other benefits.

David P. Since Mr. Cook's compensation is entirely stock based, his interests are aligned precisely with those of our stockholders. Our Board believed that the employment arrangement was appropriate in light of Mr. Cook's demonstrated prior success in founding and nurturing start-up and development-stage enterprises

The Committee decided that, beginning in 1999, Mr. Bakke would no longer receive cash as part of his overall compensation. Mr. Bakke was compensated solely by the grant of stock options (in lieu of a cash salary and cash bonus). The Committee believes that this method of compensation will align Mr. Bakke's compensation more closely with the financial interests of the Company's other shareholders.

The Board believes that the future success of the Company is dependent upon the quality and continuity of management, and that compensation programs, such as stock option grants and options in lieu of salary, are important in attracting and retaining individuals of superior ability and in motivating their efforts on behalf of Sheldon R. The Company. The Company's options in lieu of salary program allows executive officers and key employees the election to receive stock options in lieu of salary for all or a portion of their annual salary...Mr. Erikson elected to convert the equivalent of one year's base salary to stock options under the Options in Lieu of Salary Program for each of the years from 1995 through 1999 and for the years 2001 and 2002

effective with respect to 1999 compensation, salary and cash bonuses were eliminated, leaving stock options and their associated gains as the sole source of compensation. Without any base salary or bonus paid in cash, the CEO's compensation has been entirely dependent on the creation of incremental market value through setting strategic direction and achieving targeted financial performance

Prior to our Spin-off from Ralston, it was established that our Chief Executive Officer would receive stock options in lieu of salary for a period of five years. This decision was based on a desire to (1) ensure retention of our Chief Executive Officer for the first five years of operation for the new company, (2) provide appropriate compensation for our Chief Executive Officer without the need for substantial cash outlays, and (3) fully align the interests of our Chief Executive Officer with those of our shareholders. 
Washington

1999 Group Wennis R.

2000 Kinder Morgan Richard D.

2000 Oracle Corp

2000 Conseco Inc

Gary C.

Wendt

2000 Discount Auto Peter J.

Parts Inc Fontaine

2000 Extended Stay George D. America Inc

2001 Plains Resources James C. Inc

Flores

2001 Siebel Systems

Siebel

Helix Energy

Solutions Group

2001 (formerly Cal

Dive

International)

2002 Bank Of Hawaii Corp

In lieu of salary, Mr. Washington was awarded an option as of April 8, 1999, to purchase 2,000,000 shares

Mr. Kinder, at his initiative, accepted a salary of $\$ 1$ per year to demonstrate his belief in our long term viability.

CEO's compensation plan for fiscal year 2000-2003 consists of no salary and no bonus. Instead, during fiscal year 2000, on June 4, 1999, he was granted an option to purchase $10,000,000$ shares of the Company's Common Stock $(40,000,000$ shares as adjusted for the Company's two 2 -for- 1 stock splits effective January 18 ,
2000 and October 12,2000$)$ at the fair market value at the time of grant. The option vests in equal installments over a period of four years and expires ten years from the date of grant... The changes to the Chief Executive Officer's compensation plan more closely align his compensation with the Company's stock performance... [The Chief Executive Officer's compensation plan is intended more closely to align his compensation with the performance of our Common Stock.(Oracle website)]

For the first two years of his employment agreement Mr. Wendt is entitled to receive no salary...[The Compensation Committee seeks to align the interests of senior executive management with the interests of shareholders by providing for a substantial portion of the compensation paid to such officers to be tied directly to the financial results of the Company and the performance of the Common Stock. (LexisNexis)]

Mr. Fontaine was initially granted a base salary of $\$ 192,400$ for fiscal 2000, which was unchanged from his base salary for fiscal $1999 \ldots$ Effective July 8 , 1999 , however, Mr. Fontaine, in consultation with the Compensation Committee, elected to eliminate any base salary and to be compensated solely through the annual bonus.

The Company does not pay Mr. Johnson any cash salary or bonus but rather compensates him exclusively through stock option grants. We believe that tying Mr. Johnson's remuneration to the performance of the Company's Common Stock will motivate Mr. Johnson to maximize stockholder value and is consistent with our policy of compensating the Company's senior executives, like Messrs. Huizenga and Johnson, primarily through annual stock option grants.

Pursuant to his employment agreement, Mr. Flores received, in lieu of base salary, an option under our 2001 plan to purchase 1,000,000 shares of our common stock at an exercise price of $\$ 23.00$ per share

The salaries of certain of our executives were reduced by $20 \%$ in April 2001 as part of our cost control initiatives. Effective January 1, 2003, the salaries of these executives were returned to the levels prior to the reduction in April 2001. In addition, the salary of Mr. Siebel was reduced to $\$ 1$ at his request in January 2001 as part of our cost control initiatives, and remained at that level for the next three years. Effective January 1, 2004, Mr. Siebel's salary was restored to $\$ 1,000,000$

During 2000, the Board of Directors approved a "Stock Option in Lieu of Salary Program" for Mr. Kratz. Under the terms of the program, Mr. Kratz may annually elect to receive non-qualified stock options (with an exercise price equal to the closing stock price on the date of grant) in lieu of cash compensation with respect to Owen Kratz his base salary and any bonus earned under the annual incentive compensation program....the Committee believes the executive officer compensation program provides incentive to attain strong financial performance and is strongly aligned with shareholder interests...For 2003, Mr. Kratz has elected to take his salary and bonus (if any) in cash, rather than receiving non-qualified stock options.

Mr. O'Neill serves as Chairman and CEO of the Company pursuant to a written employment agreement effective as of November 3, 2000. The agreement includes Michael E. a base salary of $\$ 900,000$, subject to annual review ...To ease the expense burden of the Company... Mr. O'Neill elected to waive his base salary and any bonus for O'Neill 2002 and 2003. 

Clay Ford Jr.

2002 Lilly (Eli) \& Co Sidney Taure

Robert J.

Shillman

2002 Cisco System

John T. Chambers

2002 Franklin Covey

2003 Micron Technology Inc Appleton

2003 Bombay Co Inc James D.

Carreker

2004 CPI Corp Duke Energy Corp

David M.

Meyer

Paul M.

Anderson
At Mr. Ford's request, the Committee and Mr. Ford agreed that Mr. Ford would forego any new compensation (including salary, bonus, or other awards) until such time as the Committee and Mr. Ford determine that our Automotive sector has achieved sustained profitability. [The great-grandson of company founder Henry Ford has said he won't accept a cash salary this year as the automaker tries to restore profit. (LexisNexis)]

In light of the reduction in the company's Prozac sales, Mr. Taurel voluntarily reduced his base salary to $\$ 1.00$ for the year 2002 . The company did not offset this reduction in salary by any additional compensation but provided a benefits allowance to preserve his employee benefits at their normal level. Mr. Taurel requested this reduction to demonstrate his confidence in the company's future results and to set an example for employees. ["Since I'm asking sacrifices of everyone," he said. "I thought I should provide an example." (LexisNexis)]

Mr. Shillman elected to forego his 2002 (/2003) base salary due to the slowdown in the Corporation's business... Dr. Shillman elected to forgo both his base compensation for 2004 of $\$ 350,000$, which represented an increase of approximately $7.7 \%$ over 2003, as well as his annual bonus of $\$ 336,000 \ldots$ Dr. Shillman elected to forgo both his base compensation for fiscal 2005 of $\$ 350,000$, which represented an increase of $0 \%$ over 2004 , as well as his annual bonus of $\$ 181,650$, and requested that the Corporation donate his 2005 bonus to a public charity ... Dr. Shillman elected to forgo his base salary of $\$ 350,000$ in 2008 , 2007 and 2006 , as well as his annual bonus of $\$ 44,100, \$ 52,500$ and $\$ 130,200$ in 2008,2007 and 2006 , respectively, and, as requested by him, we donated these amounts to a public charity. Although these amounts were donated, they are included in the amount shown in the "Total Compensation" column

On April 1, 2001, Mr. Chambers requested that his base salary be lowered to a rate of $\$ 1.00$ annually(until the recognition of a recovery in Cisco's performance). On May 11, 2001, the Committee agreed to honor this request until such a time as the Committee deems it appropriate to return Mr. Chambers' base salary to a market competitive level. For fiscal year 2002 Mr. Chambers' base salary remained at $\$ 1.00$.

The agreement has an initial term expiring August 31,2007 , and provides for an annual base salary of $\$ 500,000 \ldots$ Mr. Whitman has voluntarily not taken his base salary or bonus compensation since May 2001... In June 2001, Mr. Whitman asked the Committee to discontinue paying his salary and annual incentives until the Company's performance improves.

In June of 2001 base salaries of Company officers were reduced by ten percent as a result of industry conditions and Company performance. Similarly, in October of 2001, base salaries for Company officers were reduced by an additional ten percent. At the time of the second reduction, Mr. Appleton reduced his base salary to $\$ 0$ until the Company returned to profitability.

Pursuant to his employment agreement, he was entitled to receive a base salary of $\$ 600,000$ or, if he elected to receive his base salary in the form of restricted stock vesting in full at the end of three years, he was entitled to a grant of restricted stock valued at 1.25 times base salary. He elected to take stock and was granted 81,256 shares. At January 30, 2004, the shares had a value of $\$ 611,858$. Similar elections may be made each year on or about the anniversary date of Mr. Carreker's appointment.

Mr. Meyer's compensation reflects the Company's commitment to aligning executive compensation with stockholder value.

When Anderson returned, he decided to pass up a salary as a sign of his confidence in the company, opting instead to be paid only in Duke stock. 
2004 USANA Healt Sciences Inc

2005 Fossil Inc

2005 Google Inc
The Company's Founder and Chairman, Dr. Myron W. Wentz, has also served with the title of Chief Executive Officer of USANA since its inception. Dr. Wentz does not receive any compensation for his services and he has in the past declined to accept any options or other awards under any stock option or stock incentive plan that he might otherwise have been entitled to receive as an executive officer.

For 2005, the CEO requested that he receive no salary... Based upon a consideration of these factors, the Compensation Committee determined that the Kosta N. compensation level proposed by the CEO was well below the market median. However, in light of the request by the CEO, a 2005 salary level of $\$ 0$ was approved. Kartsotis The CEO did not receive any grants of stock options in 2005...For 2006/2007/2008, Mr. Kartsotis refused all forms of compensation for fiscal 2006. Mr. Kartsotis is one of the initial investors in our Company and expressed his belief that his primary compensation is met by continuing to drive stock price growth

We view named executive officer base salaries as a tool that provides executives with a reasonable base level of monthly income relative to the jobs they are doing and market-competitive salaries. In 2004, Eric, Sergey and Larry requested that their salaries each be reduced to $\$ 1$ per year. However, due their strong leadership and Google's strong overall performance, we offered each of them market-competitive salaries at the beginning of each of 2005-now. Due to their own preferences not to receive salary compensation, Eric, Sergey and Larry each rejected these offers and continue to receive base salaries of $\$ 1 \ldots$ we increased executive officer cash compensation levels for 2007, other than for Eric, Larry and Sergey, to better reflect the competitive opportunities that Google executives have and help attract and retain senior-level executives 


\section{Appendix B}

\section{List of Variables}

"\$1 CEO": dummy variable that equals 1 if the CEO earns a dollar-a-year (or less) salary, and zero otherwise.

"\# years as a prior director (and/ or executive)": number of years as a board director (and/ or executive) prior to becoming a \$1 CEO (Source: Bloomberg).

"All other total": compensation that does not belong under other categories, which includes items such as: (1) Severance payments, (2) Debt forgiveness, (3) Imputed interest, (4) Payouts for cancellation of stock options, (5) Payment for unused vacation, (6) Tax reimbursements, (7) Signing bonuses, (8) 401K contributions, (9) Life insurance premiums (Source: Execucomp).

"Alpha": intercept of the market model estimated over the three-year period using daily returns (Source: CRSP).

"Assets growth (3 years)": 3-year average of the annual growth rate of assets (Source: Compustat).

"Beta": beta coefficient estimated from the market model based on stock daily returns over an entire fiscal year.

"Board size": total number of directors that compound the board (Source: IRRC).

"Bonus": the dollar value of a bonus earned by the named executive officer during the fiscal year (Source: Execucomp)

"Cautious"/ "Confident" (\# articles in the press): number of articles about the CEO published in a variety of sources: the main financial press (Wall Street Journal, Financial Times, Business Week, and The Economist), online financial news (PR News Wire and Business Wire), and the regular press (NY Times, Washington Post, Boston Globe, USA Today, The Times, The Guardian, and The Independent). An article is classified as "confident" when it mentions the CEO as using the words "confident", "optimistic", "confidence" or "optimism"; and it is classified as "cautious" when the CEO uses the words "reliable", "practical", "conservative", "frugal", or "steady". This methodology is based on Malmendier and Tate (2005).

"CEO Age": age of the CEO measured in years (Source: IRRC).

"Change in capex $(-1,+2)$ ": relative change in capital expenditures from one year before the CEO earns $\$ 1$ salary to two years after (Source: Compustat).

"Come-back CEO": dummy variable that equals 1 if the CEO was re-hired as a CEO by the company, and zero otherwise (Source: Execucomp).

"Continue as a CEO": dummy variable that identifies whether the CEO kept his job after the last year he received $\$ 1$ salary (Source: Execucomp).

"Coverage ratio": operating income after depr./ interest expenses (Source: Compustat).

"Delta" is the dollar change in the CEO stock and option holdings for a $1 \%$ change in the stock price (Source: CRSP/ Execucomp).

"Dividend payout": total dividends/ net income (Source: Compustat).

"Dividend yield": dividends per share/ stock price (fiscal year-end; close) (Source: CRSP).

"Duality": dummy variable that equals 1 if the CEO is also the chairman, and zero otherwise (Source: IRRC).

"Education": four dummy variables that identify whether the CEO has a $\mathrm{PhD}$, Graduate (MBA, Master), College, or High School education (Source: Hoovers and Bloomberg).

"FCF/ Total assets": free cash flow/ total assets, where "free cash flow" = net income capital expenditures - changes in working capital + depr. and amortizations (Source: Compustat).

"First-time CEO": dummy variable that equals 1 if the CEO became a CEO in the year he starts earning \$1, and zero otherwise (Source: Bloomberg).

"First-time CEO with any prior appoint.": identifies first-time CEOs with prior appointments as director and/ or executives (Source: Bloomberg). 
"First-time CEO with prior directorship": dummy variable that equals 1 if the CEO simultaneously is a "first-time CEO" and had a prior appointment as a board director (Source: Bloomberg).

"Forbes": dummy variable that equals 1 if the CEO is in the Forbes 400 list of wealthy people, and zero otherwise (Source: Forbes Magazine).

"Founder": dummy variable that identifies whether the CEO is a founder of the company (Source: Compact Disclosure).

"Gain from stockholdings" = (\# shares held by the CEO*stock price at the beginning of the fiscal year)*annual stock return (Source: Execucomp/ CRSP).

"Gender": dummy variable that equals 1 if the CEO is a female, and zero otherwise (Source: IRRC).

"G-Index" and "E-index" are, respectively, the Gompers, Ishii, and Metrick (2003) and Bebchuk, Cohen, and Ferrell (2005) corporate governance indexes.

"Idiosyncratic risk": natural $\log$ of the annualized variance of the residuals from the market model (estimated for every fiscal year). The market model is estimated with five leads and five lags of CRSP value-weighted daily returns (Source: CRSP).

"Independent committee": dummy variable that equals one if all the compensation committee members are independent; and zero otherwise.

"Institutional ownership": percentage of stock held by institutions, as reported by as of the fiscal-year end (Source: Thomson Financial 13-F).

"Lambda": inverse Mills ratio to correct for potential sample bias.

"Leverage": total liabilities/ total assets (Source: Compustat).

"LT abnormal ret": three-year cumulative return on the stock minus the three-year cumulative return on the CRSP VW index, winsorized at the 1 and 99 percentiles (Source: CRSP).

"LT CAR": the sum, over a three-year period, of the difference between stock daily returns and the daily return on CRSP VW index, winsorized at the 1 and 99 percentiles (Source: CRSP).

"LTIP payouts": amount paid out to the executive under the company's long-term incentive plan. These plans measure company performance over a period of more than one year (generally three years). (Source: Execucomp).

"Market-to-book": market value of equity/ book value of equity, winsorized at the $1 \%$ and 99\% percentiles (Source: Compustat/ CRSP).

"Market value": the sum of total liabilities plus the market value of equity (shares outstanding*stock price) at the fiscal year-end. In \$MM, adjusted to reflect 2005 prices (Source: CRSP/ Compustat).

"Non-firm CEO wealth": estimate of CEO non-firm wealth used in Dittmann and Maug (2007), calculated by cumulating all historical cash inflows and outflows as documented in Execucomp.

"Option grants": value of option-related awards (e.g. options, stock appreciation rights, and other instruments with option-like features). Valuation is based upon the value of options that vested during the year as detailed in FAS123R. The amount here is the cost recorded by the company on its income statement as well as any amounts that were capitalized on the balance sheet for the fiscal year. It discloses the cost that was charged to the company (and thus to shareholders) for the year, as distinct from the grant date fair value of the awards (Source: Execucomp).

"Options exercised": value realized from option exercises during the year. This value is calculated as of the date of exercise and is based on the difference between the exercise price and the market price of the stock on the exercise date (Source: Execucomp).

"Other annual": the dollar value of other annual compensation not properly categorized as salary or bonus. This includes items such as: (1) Perquisites and other personal benefits, (2) Above market earnings on restricted stock, options/SARs or deferred compensation paid during the year but deferred by the office, (3) Earnings on long-term incentive plan compensation paid during the year but deferred at the 
election of the officer, (4) Tax reimbursements, (5) The dollar value of difference between the price paid by the officer for company stock and the actual market price of the stock under a stock purchase plan that is not generally available to shareholders or employees of the company (Note: This does not include value realized from exercising stock options). (Source: Execucomp). "Percentage held by top-five institutions": the sum of the five largest institutional holdings (Source: Thomson Financial 13-F).

"Prct independents": total number of directors that are not employees or affiliated to the firm / board size (Source: IRRC).

"Prct of shares owned by the CEO": number of shares held by the CEO divided by the total shares outstanding (in \%). (Source: Execucomp).

"Presence of an inst. blockholder" is a dummy variable that equals 1 if the firm has an institutional shareholder holding more than $5 \%$ of the company stock, and zero otherwise (Source: Thomson Financial 13-F).

"Presence of blockholder (comp. committee)": dummy variable that equals 1 if at least one of the compensation committee members is a blockholder with the total voting power larger than one percent.

"Restricted stock grants": value of restricted stock granted during the year (determined as of the date of the grant). (Source: Execucomp).

"Risk changes": variables under this category are computed as the difference between the three-year average of each annual risk measure after the first year the CEO earns $\$ 1$ (or less), minus the three-year average of the same annual risk measure before the first year the CEO earns $\$ 1$. Risk changes are measured in terms of "Total Risk", "Systematic Risk", and "Idiosyncratic Risk".

"ROA": net income/ total assets (Source: Compustat). Note: in the probit regressions it is used a 3-year average of ROA prior to the year of $\$ 1$ salary.

"Salary": the dollar value of the base salary earned by the named executive officer during the fiscal year (Source: Execucomp).

"Sales growth (3 years)": 3 -year average of the annual growth rate of sales, winsorized at $1 \%$ and $99 \%$ levels (Source: Compustat).

"Systematic risk": natural log of the annualized variance of the product between beta and the daily market return (CRSP value-weighted index) over an entire fiscal year (Source: CRSP).

"Tenure as CEO": number of years as a CEO (Source: Execucomp).

"Tenure with the firm": number of years the CEO works for the firm (Source: Execucomp).

"Tobin's Q" = (total assets - total equity + market value of equity)/total assets) as of the fiscal-year end, winsorized at the $1 \%$ and $99 \%$ percentiles (Source: CRSP/ Compustat).

"Top tercile - Value of CEO shares": dummy variable that equals 1 if the value of the CEO stockholdings is in the top tercile of both sample and control firms, and zero otherwise (Source: Execucomp).

"Total assets": value of total assets ( $\$ \mathrm{MM})$ as of the fiscal-year end (Source: Compustat).

"Total compensation:" Salary + Bonus, + Other Annual + Total Value of Restricted Stock Granted + Long-Term Incentive Payouts + All Other Total (Source: Execucomp).

"Total Compensation Incl Options Exercised": Salary + Bonus, + Other Annual + Total Value of Restricted Stock Granted + Value Realized From Option Exercises during the year + Long-Term Incentive Payouts + All Other Total (Source: Execucomp, definition TDC2).

"Total Compensation Incl Option Grants": Salary + Bonus, + Other Annual + Total Value of Restricted Stock Granted + Total value of Options Granted (using Black-Scholes) + Long-Term Incentive Payouts + All Other Total (Source: Execucomp, definition TDC1).

"Total current compensation": Current compensation, or SALARY + BONUS (Source: Execucomp, definition TCC). 
"Total options" = options granted + unexercised exercisable options + unexercised unexercisable options (Source: Execucomp).

"Total risk": natural log of the annualized variance of daily returns of an entire fiscal year (Source: CRSP).

"Vega" is the dollar change in the CEO option holdings for a $1 \%$ change in the stock volatility (Source: CRSP/ Execucomp).

"Volatility": past 60-month standard deviation of stock returns.

"Z-score" $=0.33 *$ EBIT/total assets $+0.999 *$ net sales/total assets $+0.6 *$ Mkt value of equity/total liabilities $+1.2 *$ working capital/total assets $+1.4 *$ retained earnings/total assets (Source: Compustat).

Note: all variables expressed in US\$ are adjusted to reflect 2005 prices. 
Table 1: Hypotheses and their Predictions regarding Adoptions of \$1 CEO Salaries

\begin{tabular}{lllll}
\hline Hypotheses & $\begin{array}{l}\text { Nature of \$1 CEO } \\
\text { Salary Contract }\end{array}$ & \multicolumn{3}{c}{ Predictions } \\
\cline { 3 - 5 } & Optimal & $\begin{array}{c}\text { Motivating Factor } \\
\text { Present }\end{array}$ & $\begin{array}{c}\text { Corporate } \\
\text { Governance }\end{array}$ & $\begin{array}{c}\text { Value Effect of Adoption } \\
\text { of \$1 CEO Salary for } \\
\text { Shareholders }\end{array}$ \\
\hline Alignment & Problems & Effective & Value-creating \\
Signaling & Optimal & $\begin{array}{l}\text { Business challenge to } \\
\text { restore profitability or } \\
\text { exploit opportunities }\end{array}$ & Effective & Value-creating \\
Managerial Power & Non-optimal & $\begin{array}{l}\text { Potential for outrage } \\
\text { over private benefits }\end{array}$ & Ineffective & Value-destroying \\
\hline
\end{tabular}




\section{Table 2: Information in Proxy Statements on \$1 CEOs, 1992-2005}

Sample firms are not repeated. Whenever the CEO of a sample firm earns a $\$ 1$ (or less) salary for more than 1 consecutive year, only the first year is considered. Panel A shows the stated reasons for adopting a \$1CEO salary. Panel B shows other forms of compensation earned by the CEOs of sample firms. Panel C shows how many of the sample CEOs are first-time CEOs, that is, cases where the CEO appointment is simultaneous with the $\$ 1$ salary arrangement.

Panel A: Reason for adoption of \$1 salaries (out of 50 sample firms)

\begin{tabular}{lllc}
\hline & Reason & N & \% \\
\hline No reason cited & & 19 & $38 \%$
\end{tabular}

No. of times the reason was cited by the remaining 31 firms (62\% of sample), incl. repetitions:

To align interests of CEO and shareholders $\quad 20 \quad 40 \%$

$\begin{array}{lll}\text { To reduce costs/ aid in recovery } & 12 \quad 24 \%\end{array}$

$\begin{array}{lll}\text { To convey CEO's confidence in future } & 3 & 6 \%\end{array}$

$\begin{array}{lll}\text { To fund CEO's preferred charitable cause } & 2 & 4 \%\end{array}$

To attract superior executive (i.e., the CEO) $\quad 1 \quad 2 \%$

To share at the top in sacrifice towards recovery $\quad 1 \quad 2 \%$

Panel B: Non-salary form of compensation (out of 50 sample firms)

\begin{tabular}{lcc}
\hline \multicolumn{1}{c}{ Non-salary forms of compensation } & N & $\mathbf{\%}$ \\
\hline Bonus awards & 6 & $12 \%$ \\
Options & 35 & $70 \%$ \\
Equity-based awards & 39 & $78 \%$ \\
Explicit statement that equity-based compensation are in lieu of salary & 19 & $38 \%$ \\
Automatic gain as major stockholder (holdings > 5\% of outst. stock) & 25 & $50 \%$ \\
\hline
\end{tabular}

Panel C: Appointment of \$1 salary CEO (out of 50 sample firms)

\begin{tabular}{ccc}
\hline Appointment of \$1 salary CEOs & N & \% \\
\hline Simultaneous appointment as CEO with a \$1 salary arrangement & 23 & $46 \%$ \\
\hline
\end{tabular}




\section{Table 3: Incidence of \$1 CEOs}

Panel A shows the number and percentage of total and new cases per year of CEOs that were paid a $\$ 1$ (or less) salary. It also shows the distribution of new cases according to the exchange on which they are listed. Panel B shows the frequency and selected descriptive statistics of the number of consecutive years the CEO earns $\$ 1$. Panel $\mathrm{C}$ shows the frequency of cases by industry.

Panel A: Incidence of \$1 salary CEOs: all cases, new cases, by exchange and year

\begin{tabular}{|c|c|c|c|c|c|c|c|}
\hline \multirow[t]{2}{*}{ Year } & \multicolumn{3}{|c|}{ exchange } & \multirow{2}{*}{$\begin{array}{l}\text { Total } \\
\text { New } \\
\text { cases }\end{array}$} & \multirow{2}{*}{$\begin{array}{c}\text { New } \\
\text { cases }(\%)\end{array}$} & \multirow{2}{*}{$\begin{array}{c}\text { All } \\
\text { cases }\end{array}$} & \multirow{2}{*}{$\begin{array}{c}\text { All cases } \\
(\%)\end{array}$} \\
\hline & NYSE & Nasdaq & OTC & & & & \\
\hline 1992 & 1 & 0 & 0 & 1 & 2.00 & 1 & 0.74 \\
\hline 1993 & 2 & 0 & 0 & 2 & 4.00 & 3 & 2.21 \\
\hline 1994 & 1 & 0 & 0 & 1 & 2.00 & 3 & 2.21 \\
\hline 1995 & 0 & 1 & 0 & 1 & 2.00 & 3 & 2.21 \\
\hline 1996 & 5 & 0 & 0 & 5 & 10.00 & 7 & 5.15 \\
\hline 1997 & 4 & 2 & 0 & 6 & 12.00 & 11 & 8.09 \\
\hline 1998 & 4 & 1 & 1 & 6 & 12.00 & 14 & 10.29 \\
\hline 1999 & 5 & 2 & 0 & 7 & 14.00 & 17 & 12.50 \\
\hline 2000 & 4 & 1 & 0 & 5 & 10.00 & 13 & 9.56 \\
\hline 2001 & 1 & 2 & 0 & 3 & 6.00 & 13 & 9.56 \\
\hline 2002 & 4 & 2 & 0 & 6 & 12.00 & 16 & 11.76 \\
\hline 2003 & 2 & 0 & 0 & 2 & 4.00 & 14 & 10.29 \\
\hline 2004 & 2 & 1 & 0 & 3 & 6.00 & 11 & 8.09 \\
\hline 2005 & 0 & 2 & 0 & 2 & 4.00 & 10 & 7.35 \\
\hline Total & 35 & 14 & 1 & 50 & 100 & 136 & 100 \\
\hline
\end{tabular}

Panel B: Number of consecutive years the CEO earns a $\$ 1$ salary

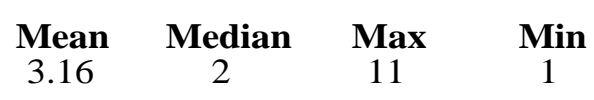

\begin{tabular}{cc}
\hline $\begin{array}{c}\text { Number of } \\
\text { consecutive } \\
\text { years of } \$ 1 \text { salary }\end{array}$ & Frequency \\
\hline 1 & 15 \\
2 & 12 \\
3 & 10 \\
4 & 5 \\
5 & 1 \\
6 & 1 \\
7 & 2 \\
11 & 4 \\
\hline
\end{tabular}


Panel C: Incidence by industry (only new cases, no repeated firms)

\begin{tabular}{lcl}
\hline & \# Industries & \multicolumn{1}{c}{ Industry Names } \\
\hline 1 FIRM & 46 & VARIOUS \\
2 FIRMS & 3 & NATURAL GAS TRANSMISSION \\
& & PHARMACEUTICAL \\
& & TELEVISION BROADCAST \\
5 FIRMS & 1 & PREPACKAGED SOFTWARE \\
\hline
\end{tabular}




\section{Table 4: CEO profile}

Sample firms are not repeated. Whenever the CEO of a sample firm earns a $\$ 1$ (or less) salary for more than 1 consecutive year, only the first year is considered. Control firms are from the CRSP/Compustat universe, matched with sample firms by 4-digit SIC codes and year. The variables in this table characterize the CEO profile. All variables are defined in Appendix B. The last two columns show t-stats and Wilcoxon-stats from the tests of equality of means and medians, respectively. *,**,*** stand for statistical significance at $10 \%, 5 \%$, and $1 \%$ levels, respectively.

\section{Panel A: Personal Characteristics}

\begin{tabular}{|c|c|c|c|c|c|c|c|c|c|c|}
\hline \multirow[b]{2}{*}{ Variables } & \multicolumn{4}{|c|}{ Sample firms } & \multicolumn{4}{|c|}{ Control firms } & \multicolumn{2}{|c|}{ Sample - Controls } \\
\hline & Mean & $\mathbf{N}$ & 50th Petl & Std Dev & Mean & $\mathbf{N}$ & 50th Petl & Std Dev & $\begin{array}{l}\text { t-stats } \\
\text { means }\end{array}$ & $\begin{array}{c}\text { Wilcoxon } \\
\text { medians }\end{array}$ \\
\hline CEO Age & 54.1 & 50 & 53.5 & 7.941 & 52.9 & 243 & 53 & 7.856 & 1.01 & 0.66 \\
\hline Gender (\% of female CEOs) & $0.00 \%$ & 0 & & & $0.41 \%$ & 1 & & & -1.00 & \\
\hline \multicolumn{11}{|l|}{ Education: } \\
\hline $\mathrm{PhD}$ & $20.00 \%$ & 10 & & & $14.63 \%$ & 36 & & & 0.87 & \\
\hline Graduate (MBA, Master) & $32.00 \%$ & 16 & & & $31.71 \%$ & 78 & & & 0.04 & \\
\hline College & $28.00 \%$ & 14 & & & $28.46 \%$ & 70 & & & -0.06 & \\
\hline High School & $6.00 \%$ & 3 & & & $1.22 \%$ & 3 & & & 1.38 & \\
\hline Unknown & $14.00 \%$ & 7 & & & $23.98 \%$ & 59 & & & $-1.76^{*}$ & \\
\hline "Cautious" (\# articles in the press) & 0.26 & 50 & 0.00 & 0.69 & 0.35 & 246 & 0.00 & 0.84 & -0.77 & -0.67 \\
\hline "Confident" (\# articles in the press) & 0.98 & 50 & 0.50 & 1.38 & 0.55 & 246 & 0.00 & 0.86 & $2.88^{* * *}$ & $2.17^{* *}$ \\
\hline Total observations & & 50 & & & & 246 & & & & \\
\hline
\end{tabular}

Panel B: Indicators of personal wealth

\begin{tabular}{|c|c|c|c|c|c|c|c|c|c|c|}
\hline \multirow[b]{2}{*}{ Variables } & \multicolumn{4}{|c|}{ Sample firms } & \multicolumn{4}{|c|}{ Control firms } & \multicolumn{2}{|c|}{ Sample - Controls } \\
\hline & Mean & $\mathbf{N}$ & 50th Petl & Std Dev & Mean & $\mathbf{N}$ & 50th Petl & Std Dev & $\begin{array}{l}\text { t-stats } \\
\text { means }\end{array}$ & $\begin{array}{l}\text { Wilcoxon } \\
\text { medians }\end{array}$ \\
\hline Forbes & $30.00 \%$ & 15 & & & $4.47 \%$ & 11 & & & $3.82 * * *$ & \\
\hline Value of CEO shares - top tercile & $68.00 \%$ & 34 & & & $30.08 \%$ & 74 & & & $5.21 * * *$ & \\
\hline Value of CEO shares - top quintile & $40.00 \%$ & 20 & & & $17.48 \%$ & 43 & & & $3.04 * * *$ & \\
\hline Forbes and/or Value of CEO shr - top tercile & $76.00 \%$ & 38 & & & $31.30 \%$ & 77 & & & $6.59 * * *$ & \\
\hline Non-firm CEO wealth (\$ MM) & 49.52 & 36 & 3.71 & 175.99 & 184.65 & 207 & 6.28 & 1790.45 & -0.45 & -1.50 \\
\hline Total observations & & 50 & & & & 246 & & & & \\
\hline
\end{tabular}

Panel C: History with the firm

\begin{tabular}{|c|c|c|c|c|c|c|c|c|c|c|}
\hline \multirow[t]{2}{*}{ Variables } & \multicolumn{4}{|c|}{ Sample firms } & \multicolumn{4}{|c|}{ Control firms } & \multicolumn{2}{|c|}{ Sample - Controls } \\
\hline & Mean & $\mathbf{N}$ & 50th Pctl & Std Dev & Mean & $\mathbf{N}$ & 50th Pctl & Std Dev & t-stats & Wilcoxon \\
\hline Tenure as CEO (years) & 2.60 & 50 & 1.0 & 2.416 & 4.07 & 246 & 3.0 & 2.688 & $-3.84 * * *$ & $-4.26 * * *$ \\
\hline Tenure with the firm (years) & 9.05 & 50 & 3.7 & 11.575 & 9.88 & 246 & 7.1 & 9.215 & -0.48 & $-1.99 * *$ \\
\hline Founder & $18.00 \%$ & 9 & & & $17.07 \%$ & 42 & & & 0.15 & \\
\hline Come-back CEO & $4.00 \%$ & 2 & & & $2.44 \%$ & 6 & & & 0.53 & \\
\hline First-time CEO & $46.00 \%$ & 23 & & & $19.92 \%$ & 49 & & & $4.12 * * *$ & \\
\hline First-time CEO with prior directorship & $10.00 \%$ & 5 & & & $10.98 \%$ & 27 & & & -0.42 & \\
\hline First-time CEO with any prior appointment & $26.00 \%$ & 13 & & & $13.41 \%$ & 33 & & & $2.32 * * *$ & \\
\hline \# Years as a prior director & 6.44 & 34 & 4.50 & 6.14 & 7.96 & 218 & 6.00 & 7.55 & -1.3 & -1.07 \\
\hline \# Years as a prior director and/or executive & 9.91 & 34 & 6.50 & 9.56 & 11.40 & 220 & 10.00 & 9.09 & -0.85 & -1.13 \\
\hline Continue as CEO & $48.00 \%$ & 24 & & & $54.07 \%$ & 133 & & & 1.24 & \\
\hline Prct shares owned by the CEO & $10.09 \%$ & 47 & $3.75 \%$ & 12.57 & $3.21 \%$ & 216 & $1.15 \%$ & 6.61 & $3.64 * * *$ & $5.06 * * *$ \\
\hline Total observations & & 50 & & & & 246 & & & & \\
\hline
\end{tabular}




\section{Table 5: Firm characteristics}

"Sample firms" are not repeated. Whenever the CEO of a "sample firm" earns a \$1 (or less) salary for more than 1 consecutive year, only the first year is considered. Control firms are from the CRSP/Compustat universe, matched with sample firms by 4-digit SIC codes and year. Accounting variables are from Compustat as of the end of the respective fiscal year. Stock price data are from CRSP. Variables expressed in dollars are adjusted to reflect 2005 prices. All variables are defined in Appendix B. The last two columns show t-stats and Wilcoxon-stats from the tests of equality of means and medians, respectively. *, **, *** stand for statistical significance at $10 \%, 5 \%$, and $1 \%$ levels, respectively.

\begin{tabular}{|c|c|c|c|c|c|c|c|c|c|}
\hline & \multirow[b]{2}{*}{ Variables } & \multicolumn{3}{|c|}{ Sample Firms } & \multicolumn{3}{|c|}{ Control Firms } & \multicolumn{2}{|c|}{ Sample - Controls } \\
\hline & & Mean & $\mathbf{N}$ & 50th Pctl & Mean & $\mathbf{N}$ & 50th Petl & $\begin{array}{l}\text { t-stats } \\
\text { means }\end{array}$ & $\begin{array}{c}\text { Wilcoxon } \\
\text { medians }\end{array}$ \\
\hline \multirow{2}{*}{ Size } & Total assets (\$MM) & $14,459.27$ & 50 & $1,830.45$ & $10,843.36$ & 246 & $2,005.28$ & 0.69 & -0.31 \\
\hline & Market value (\$MM) & $26,576.86$ & 50 & $4,173.04$ & $24,221.61$ & 245 & $5,268.34$ & 0.23 & -0.79 \\
\hline \multirow{5}{*}{ Growth } & Tobin's Q & 2.880 & 47 & 1.865 & 3.301 & 244 & 1.667 & -0.74 & -0.14 \\
\hline & Sales growth (3 years) & 0.492 & 50 & 0.149 & 0.226 & 246 & 0.134 & $3.23 * * *$ & 0.36 \\
\hline & Assets growth (3 years) & 0.740 & 50 & 0.130 & 0.386 & 246 & 0.174 & $1.92 *$ & -1.15 \\
\hline & Change capex $(-1,+2)$ & 1.580 & 36 & 0.427 & 0.497 & 176 & 0.050 & $2.17 *$ & 1.52 \\
\hline & Past sales/assets & 0.055 & 47 & -0.022 & -0.026 & 244 & -0.042 & $2.56^{* *}$ & 0.97 \\
\hline \multirow{3}{*}{ Risk changes } & Total Risk & -0.135 & 48 & -0.089 & -0.115 & 245 & -0.031 & -0.14 & -0.11 \\
\hline & Systematic Risk & 0.137 & 48 & -0.056 & 0.155 & 245 & 0.223 & -0.12 & -0.36 \\
\hline & Idiosyncratic risk & -0.197 & 48 & -0.097 & -0.219 & 245 & -0.179 & 0.16 & 0.21 \\
\hline \multirow{4}{*}{$\begin{array}{l}\text { Betas and } \\
\text { volatility }\end{array}$} & Avg. beta (ex-ante) & 1.182 & 48 & 1.187 & 1.300 & 246 & 1.225 & -0.99 & -0.68 \\
\hline & Avg. beta (ex-post) & 1.209 & 49 & 1.083 & 1.351 & 245 & 1.184 & -1.00 & -1.46 \\
\hline & Change in beta & 0.021 & 48 & -0.206 & 0.058 & 245 & 0.108 & -0.30 & -1.60 \\
\hline & Volatility & 0.491 & 49 & 0.439 & 0.526 & 235 & 0.498 & -0.90 & -0.30 \\
\hline \multirow{4}{*}{$\begin{array}{l}\text { Capital } \\
\text { Structure }\end{array}$} & Leverage & 0.566 & 50 & 0.565 & 0.504 & 245 & 0.495 & 1.58 & 1.63 \\
\hline & Change in leverage & 0.013 & 50 & 0.009 & 0.011 & 245 & -0.001 & 0.11 & 0.00 \\
\hline & Coverage ratio & 78.96 & 43 & 2.73 & 280.62 & 170 & 2.96 & -0.46 & -0.08 \\
\hline & Z-score & 8.814 & 46 & 3.122 & 11.010 & 216 & 4.053 & -0.50 & -1.16 \\
\hline \multirow{4}{*}{$\begin{array}{c}\text { Past } \\
\text { performance } \\
\text { (three years) }\end{array}$} & ROA & 0.022 & 50 & 0.028 & 0.054 & 246 & 0.042 & $-2.23 * *$ & $-2.24 * *$ \\
\hline & LT abnormal ret & 0.905 & 50 & -0.069 & 0.924 & 246 & -0.026 & -0.04 & -0.01 \\
\hline & LT CAR & 0.354 & 50 & 0.217 & 0.515 & 246 & 0.276 & -1.02 & -0.89 \\
\hline & Alpha $\left(10^{\wedge} 3\right)$ & 0.639 & 48 & 0.384 & 0.603 & 246 & 0.301 & 0.17 & 0.06 \\
\hline \multirow{4}{*}{$\begin{array}{c}\text { Dividends \& } \\
\text { Cash }\end{array}$} & Cash/ Total assets & 0.123 & 50 & 0.078 & 0.130 & 239 & 0.092 & -0.34 & -0.54 \\
\hline & FCF/ Total as sets & -0.036 & 30 & -0.011 & -0.023 & 136 & -0.022 & -0.33 & -0.52 \\
\hline & Dividend yield & 0.007 & 50 & 0.000 & 0.012 & 246 & 0.000 & -1.64 & -1.18 \\
\hline & Dividend payout & 0.140 & 37 & 0.000 & 0.137 & 202 & 0.000 & 0.04 & -0.90 \\
\hline
\end{tabular}




\section{Table 6: Corporate Governance}

Sample firms are not repeated. Whenever the CEO of a sample firm earns a $\$ 1$ (or less) salary for more than 1 consecutive year, only the first year is considered. Control firms are from the CRSP/Compustat universe, matched with sample firms by 4-digit SIC codes and year. Except from institutional ownership, data come from IRRC. All variables are defined in Appendix B. Whenever data on sample firms are missing we obtain them manually from Proxy Statements. The last two columns show t-stats and Wilcoxon-stats from the tests of equality of means and medians, respectively. *,**, *** stand for statistical significance at $10 \%, 5 \%$, and $1 \%$ levels, respectively.

\begin{tabular}{|c|c|c|c|c|c|c|c|c|c|c|}
\hline \multirow[b]{2}{*}{ Variables } & \multicolumn{4}{|c|}{ Sample firms } & \multicolumn{4}{|c|}{ Control firms } & \multicolumn{2}{|c|}{ Sample - Controls } \\
\hline & Mean & $\mathbf{N}$ & 50th Pctl & Std Dev & Mean & $\mathbf{N}$ & 50th Pctl & Std Dev & $\begin{array}{l}\text { t-stats } \\
\text { means }\end{array}$ & $\begin{array}{c}\text { Wilcoxon } \\
\text { medians }\end{array}$ \\
\hline \multicolumn{11}{|l|}{ Board } \\
\hline Size & 8.83 & 47 & 8.00 & 3.17 & 8.84 & 243 & 8.00 & 3.13 & -0.02 & -0.03 \\
\hline Number of independents & 5.32 & 47 & 5.00 & 2.70 & 5.84 & 243 & 5.00 & 2.91 & -1.13 & -0.62 \\
\hline Prct independents & $59.05 \%$ & 47 & $62.50 \%$ & 0.19 & $64.53 \%$ & 243 & $66.67 \%$ & 0.16 & $-2.10 * *$ & -1.61 \\
\hline Duality ( $\%$ of CEOs that are also chairman) & $74.47 \%$ & 47 & 1.00 & 0.44 & $65.02 \%$ & 243 & 1.00 & 0.48 & 1.26 & 1.25 \\
\hline \multicolumn{11}{|l|}{ Ownership } \\
\hline Prct of shares owned by the CEO & $10.09 \%$ & 47 & $3.75 \%$ & 12.57 & $3.21 \%$ & 216 & $1.15 \%$ & 6.61 & $5.34 * * *$ & $5.06 * * *$ \\
\hline Institutional ownership & $53.30 \%$ & 50 & $56.27 \%$ & 0.21 & $61.19 \%$ & 246 & $62.07 \%$ & 0.18 & $-2.78 * *$ & $-2.13 * *$ \\
\hline Presence of an inst. blockholder & $84.00 \%$ & 50 & 1.00 & 0.37 & $88.62 \%$ & 246 & 1.00 & 0.32 & -0.91 & -0.91 \\
\hline \multicolumn{11}{|l|}{ Anti-takeover protection } \\
\hline G-index & 8.20 & 30 & 8.00 & 2.85 & 8.54 & 210 & 8.00 & 2.57 & -0.67 & -0.61 \\
\hline E-index & 1.80 & 30 & 1.00 & 1.54 & 1.90 & 210 & 2.00 & 1.29 & -0.37 & -0.58 \\
\hline \multicolumn{11}{|l|}{ Compensation Committee } \\
\hline Independent committee & $34.00 \%$ & 50 & 0.00 & 0.48 & $67.48 \%$ & 246 & 1.00 & 0.47 & $-4.52 * * *$ & \\
\hline Presence of a blockholder & $2.00 \%$ & 50 & 0.00 & 0.14 & $6.10 \%$ & 246 & 0.00 & 0.24 & -1.63 & \\
\hline
\end{tabular}




\section{Table 7: Compensation variables}

Sample firms are not repeated. Whenever the CEO of a sample firm earns a $\$ 1$ (or less) salary for more than 1 consecutive year, only the first year is considered. Control firms are from the CRSP/Compustat universe, matched with sample firms by 4-digit SIC codes and year. All variables are adjusted to reflect 2005 prices. For definitions see Appendix B. The last two columns show t-stats and Wilcoxon-stats from the tests of equality of means and medians, respectively. *, **, *** stand for statistical significance at $10 \%, 5 \%$, and $1 \%$ levels, respectively.

\begin{tabular}{|c|c|c|c|c|c|c|c|c|c|c|}
\hline \multirow{2}{*}{ Variables } & \multicolumn{4}{|c|}{ Sample firms } & \multicolumn{4}{|c|}{ Control firms } & \multicolumn{2}{|c|}{ Sample - Controls } \\
\hline & Mean & $\mathbf{N}$ & 50th Pctl & Std Dev & Mean & $\mathbf{N}$ & 50th Pctl & Std Dev & $\begin{array}{l}\text { t-stats } \\
\text { means }\end{array}$ & $\begin{array}{c}\text { Wilcoxon } \\
\text { medians }\end{array}$ \\
\hline Salary (\$Thous) & 0.00 & 50 & 0.00 & 0.00 & 673.59 & 246 & 610.44 & 349.45 & $13.61 * * *$ & $-11.14 * * *$ \\
\hline Bonus (\$Thous) & 161.49 & 50 & 0.00 & 468.33 & 695.70 & 246 & 438.07 & $1,265.63$ & $-2.91 * * *$ & $-6.87 * * *$ \\
\hline Total Current Compensation & 161.49 & 50 & 0.00 & 468.33 & $1,369.30$ & 246 & $1,082.24$ & $1,428.97$ & $-5.91 * * *$ & $-9.68 * * *$ \\
\hline Other Annual (\$Thous) & 60.51 & 50 & 0.00 & 182.78 & 39.68 & 246 & 0.00 & 199.43 & 0.68 & 0.36 \\
\hline Restricted Stock Grants (\$Thous) & 763.89 & 50 & 0.00 & $3,960.36$ & 516.00 & 246 & 0.00 & $2,058.09$ & 0.64 & -1.01 \\
\hline LTIP Payouts (\$Thous) & 64.55 & 50 & 0.00 & 348.75 & 366.99 & 246 & 0.00 & $2,548.53$ & -0.84 & $-1.95^{*}$ \\
\hline All Other Total (\$Thous) & $1,157.29$ & 50 & 0.00 & $7,363.22$ & 252.08 & 246 & 12.32 & $1,338.98$ & $1.80 *$ & $-4.77 * * *$ \\
\hline Total Compensation & $2,207.73$ & 50 & 25.87 & $11,284.48$ & $2,544.06$ & 246 & $1,288.48$ & $4,649.56$ & -0.35 & $-7.81 * * *$ \\
\hline Gain from stock holdings (\$Thous) & $76,594.18$ & 40 & $2,078.08$ & $607,561.65$ & $112,578.11$ & 230 & 182.75 & $1,528,834.41$ & -0.15 & 1.48 \\
\hline Option Grants (\$Thous) & $12,675.56$ & 50 & $3,349.17$ & $38,970.58$ & $5,853.02$ & 246 & $1,343.12$ & $13,914.75$ & $2.16^{* *}$ & 0.92 \\
\hline Total Comp. plus gain from stk. holdings & $77,241.56$ & 40 & $2,583.01$ & $607,513.69$ & $114,803.49$ & 230 & $2,296.41$ & $1,528,740.67$ & -0.15 & 0.42 \\
\hline Total Compensation Incl Option Grants & $14,883.30$ & 50 & $4,465.69$ & $41,439.21$ & $8,397.07$ & 246 & $3,680.78$ & $14,954.21$ & $1.92 *$ & 1.11 \\
\hline
\end{tabular}




\section{Table 8: Regressions of total compensation}

The observations used in these regressions include sample firms and control firms. Sample firms are those in which CEO earns a salary of $\$ 1$ (or less). Sample firms are not repeated. Whenever the CEO earns $\$ 1$ (or less) for more than one consecutive year, only the first year is considered. Control firms are from CRSP/ Compustat universe, matched with sample firms by 4-digit SIC codes and year. The table shows OLS regressions of total compensation. Variables expressed in dollars are adjusted to reflect 2005 prices. All variables are defined in Appendix B. White-robust t-stats (absolute value) are shown in parenthesis. *, **, and *** stand for statistical significance at $10 \%, 5 \%$, and $1 \%$ levels, respectively.

\begin{tabular}{lcccc}
\hline & \multicolumn{2}{c}{ Log total cash compensation } & \multicolumn{2}{c}{$\begin{array}{c}\text { Log tot compensation incl. } \\
\text { Options granted }\end{array}$} \\
& $(1)$ & $(2)$ & $(3)$ & $(4)$ \\
\hline Log of total assets (t-1) & 0.092 & $0.152^{*}$ & $0.220^{* *}$ & $0.195^{* *}$ \\
& $(0.88)$ & $(1.83)$ & $(2.07)$ & $(2.24)$ \\
ROA (past 3-year avg.) & 1.344 & 1.462 & 2.138 & 2.256 \\
& $(0.97)$ & $(1.04)$ & $(1.35)$ & $(1.37)$ \\
Board size & 0.022 & 0.051 & 0.043 & 0.046 \\
& $(0.45)$ & $(0.97)$ & $(0.81)$ & $(0.82)$ \\
Log CEO tenure & -0.043 & -0.001 & 0.074 & 0.055 \\
& $(0.27)$ & $(0.01)$ & $(0.50)$ & $(0.37)$ \\
Tobin's Q (t-1) & -0.019 & -0.030 & 0.046 & 0.046 \\
& $(0.77)$ & $(1.35)$ & $(1.14)$ & $(1.21)$ \\
Total risk (t-1) & $-0.369 *$ & & 0.191 & \\
& $(1.96)$ & & $(1.23)$ & \\
Beta (t-1) & & -0.181 & & $0.269^{*}$ \\
& & $(0.99)$ & & $(1.94)$ \\
\$1 CEO & $-3.200^{* * *}$ & $-3.176^{* * *}$ & -0.626 & -0.577 \\
& $(3.77)$ & $(3.70)$ & $(1.07)$ & $(1.01)$ \\
Constant & $9.242^{* * *}$ & $5.871^{* * *}$ & $4.279^{* *}$ & $5.588^{* * *}$ \\
& $(3.93)$ & $(6.46)$ & $(2.39)$ & $(8.87)$ \\
Observations & 273 & 273 & 283 & 283 \\
R-squared & 0.30 & 0.29 & 0.08 & 0.08 \\
\hline
\end{tabular}




\section{Table 9: Probit regressions - Alignment Hypothesis}

The observations used in these regressions include sample firms and control firms. Sample firms are those in which the CEO earns a salary of $\$ 1$ (or less). Sample firms are not repeated. Whenever the CEO earns $\$ 1$ (or less) for more than one consecutive year, only the first year is considered. Control firms are from the CRSP/Compustat universe, matched with sample firms by 4-digit SIC codes and year. The dependent variable is a dummy variable that equals 1 when the CEO earns a salary of $\$ 1$ (or less), and 0 otherwise. All variables are defined in Appendix B. Delta and Vega are measured in $\$ 10^{5}$ units. The table reports marginal effects of the probit regressions. White-robust $\mathrm{t}$-stats (absolute values) are shown in parenthesis. *, **, and *** stand for statistical significance at $10 \%, 5 \%$, and $1 \%$ levels, respectively.

\begin{tabular}{lcccc}
\hline & $(1)$ & $(2)$ & $(3)$ & $(4)$ \\
\hline Log total assets (t-1) & -0.018 & 0.008 & & \\
& $(0.85)$ & $(0.42)$ & & \\
FCF/ Total assets (t-1) & -0.044 & -0.014 & & \\
& $(0.26)$ & $(0.10)$ & & \\
Leverage (t-1) & 0.027 & -0.071 & & \\
& $(0.18)$ & $(0.53)$ & & \\
Delta (t-1) & & -0.019 & & \\
& & $(0.53)$ & & -0.005 \\
Market-to-book (t-1) & & & -0.006 & $(1.08)$ \\
& & & $0.030 * *$ & 0.022 \\
Total options (t-1) & & & $(2.53)$ & $(1.46)$ \\
& & & -0.055 & -0.061 \\
Volatility (t-5:t-1) & & & $(0.71)$ & $(0.75)$ \\
& & & & 4.093 \\
Vega (t-1) & & & & $(0.58)$ \\
& & & 258 & 243 \\
Observations & 166 & 135 & 0.03 & 0.03 \\
Pseudo R-squared & 0.01 & 0.00 & 0.14 \\
Actual Prob. & 0.14 & 0.09 & 0.14 & 0.14 \\
\hline
\end{tabular}




\section{Table 10: Probit regressions - Signaling and Managerial Power Hypotheses}

The observations used in these regressions include sample and control firms. Sample firms are those in which the CEO earns a salary of \$1 (or less). Sample firms are not repeated. Whenever the CEO earns \$1 (or less) for more than one consecutive year, only the first year is considered. Control firms are from the CRSP/Compustat universe, matched with sample firms by 4-digit SIC codes and year. The dependent variable is a dummy variable that equals 1 when the CEO earns a salary of $\$ 1$ (or less), and 0 otherwise. All variables are defined in Appendix B. The table reports marginal effects of the probit regressions. White-robust t-stats (absolute values) are shown in parenthesis.*, **, and $* * *$ stand for statistical significance at $10 \%, 5 \%$, and $1 \%$ levels, respectively.

\begin{tabular}{|c|c|c|c|c|c|c|c|}
\hline & (1) & (2) & (3) & (4) & $(5)$ & $(6)$ & (7) \\
\hline \multirow[t]{2}{*}{ Log total assets $(\mathrm{t}-1)$} & -0.009 & 0.007 & -0.010 & -0.001 & 0.003 & 0.011 & -0.008 \\
\hline & $(0.47)$ & $(0.39)$ & $(0.56)$ & $(0.07)$ & $(0.17)$ & $(0.65)$ & $(0.46)$ \\
\hline \multirow[t]{2}{*}{$\mathrm{ROA}(\mathrm{t}-1)$} & -0.205 & $-0.315^{*}$ & -0.118 & -0.173 & -0.107 & -0.145 & -0.048 \\
\hline & $(1.14)$ & $(1.66)$ & $(0.67)$ & $(0.99)$ & $(0.63)$ & $(0.91)$ & $(0.29)$ \\
\hline \multirow[t]{2}{*}{ Leverage $(\mathrm{t}-1)$} & $0.290 * *$ & $0.270 *$ & 0.174 & $0.270 *$ & 0.171 & 0.141 & 0.217 \\
\hline & $(2.09)$ & $(1.81)$ & $(1.23)$ & $(1.87)$ & $(1.25)$ & $(1.00)$ & $(1.63)$ \\
\hline \multirow[t]{2}{*}{ Assets growth (past 3-year averag } & 0.019 & -0.025 & $0.026^{*}$ & 0.015 & 0.021 & $0.022 *$ & $0.024 *$ \\
\hline & $(1.24)$ & $(0.85)$ & $(1.72)$ & $(1.03)$ & $(1.47)$ & $(1.79)$ & $(1.82)$ \\
\hline \multirow[t]{2}{*}{ Prct Shares owned by the CEO } & $0.007 * * *$ & $0.008 * *$ & $0.006 * *$ & $0.006 * *$ & $0.006^{* *}$ & $0.006^{* *}$ & $0.006^{* *}$ \\
\hline & $(2.64)$ & $(2.30)$ & $(2.36)$ & $(2.30)$ & $(2.25)$ & $(2.47)$ & $(2.28)$ \\
\hline \multirow[t]{2}{*}{ Top tercile - Value of CEO shares } & $0.194 * * *$ & $0.178 * * *$ & $0.210 * * *$ & $0.201 * * *$ & $0.216^{* * *}$ & $0.206^{* * *}$ & $0.204 * * *$ \\
\hline & $(3.39)$ & $(2.95)$ & $(3.77)$ & $(3.45)$ & $(3.79)$ & $(3.80)$ & $(3.58)$ \\
\hline \multirow[t]{2}{*}{ Institutional Ownership } & & & & $-0.263^{* *}$ & $-0.285^{* *}$ & $-0.227 * *$ & $-0.247 * *$ \\
\hline & & & & $(2.09)$ & $(2.33)$ & $(2.05)$ & $(2.00)$ \\
\hline \multirow[t]{2}{*}{ Board size } & & & & -0.010 & -0.013 & -0.010 & -0.011 \\
\hline & & & & $(1.09)$ & $(1.45)$ & $(1.10)$ & $(1.23)$ \\
\hline \multirow[t]{2}{*}{ Prct independents } & & & & 0.084 & 0.112 & 0.222 & 0.079 \\
\hline & & & & $(0.54)$ & $(0.75)$ & $(1.41)$ & $(0.54)$ \\
\hline \multirow[t]{2}{*}{ "Confident" (\# articles in the press) } & & & & & & & $0.051 * *$ \\
\hline & & & & & & & $(2.24)$ \\
\hline \multirow[t]{2}{*}{ "Cautious" (\# articles in the press) } & & & & & & & -0.010 \\
\hline & & & & & & & $(0.35)$ \\
\hline \multirow[t]{2}{*}{ Independent committee } & & & & & & $-0.141 * * *$ & \\
\hline & & & & & & (3.03) & \\
\hline \multirow[t]{2}{*}{ Presence of a blockholder } & & & & & & -0.057 & \\
\hline & & & & & & $(0.60)$ & \\
\hline \multirow[t]{2}{*}{ Change capex $(-1,+2)$} & & $0.028 * *$ & & & & & \\
\hline & & $(2.09)$ & & & & & \\
\hline \multirow[t]{2}{*}{ Tobin's Q (t-1) } & & & $-0.019 *$ & & $-0.023 * *$ & $-0.014^{*}$ & $-0.018 * *$ \\
\hline & & & $(1.80)$ & & $(2.30)$ & $(1.77)$ & $(2.14)$ \\
\hline \multirow[t]{2}{*}{ LT abnormal ret (past 3 years) } & & & -0.062 & & 0.010 & & \\
\hline & & & $(1.55)$ & & $(1.12)$ & & \\
\hline \multirow[t]{2}{*}{ LT CAR (past 3 years) } & & & 0.022 & & & & \\
\hline & & & $(1.63)$ & & & & \\
\hline Observations & 262 & 210 & 262 & 262 & 261 & 262 & 262 \\
\hline Pseudo R-squared & 0.18 & 0.21 & 0.21 & 0.20 & 0.23 & 0.26 & 0.25 \\
\hline Actual Prob. & 0.18 & 0.17 & 0.18 & 0.18 & 0.18 & 0.18 & 0.18 \\
\hline
\end{tabular}




\section{Table 11: CEO overconfidence}

Sample firms are those in which the CEO earns a salary of $\$ 1$ (or less). Sample firms are not repeated. Whenever the CEO earns \$1 (or less) for more than one consecutive year, only the first year is considered. Control firms are from the CRSP/Compustat universe, matched with sample firms by 4-digit SIC codes and year. Figures in Panel A include articles published in the year when the CEO started earning a dollar-salary and Panel $\mathrm{B}$ includes articles published in the previous year. As described in Appendix B, the articles are from a variety of sources and their classification as "confident" or "cautious" follow the methodology of Malmendier and Tate (2005). *, **, and *** stand for statistical significance at $10 \%, 5 \%$, and $1 \%$ levels, respectively.

Panel A: Articles in the year in which the CEO started earning a dollar-a-year salary

\begin{tabular}{|c|c|c|c|c|c|c|c|c|c|}
\hline & \multicolumn{3}{|c|}{ Total Number of articles } & \multicolumn{2}{|c|}{$\begin{array}{c}\text { Average number of } \\
\text { articles }\end{array}$} & \multicolumn{2}{|c|}{$\begin{array}{c}\text { Median number of } \\
\text { articles }\end{array}$} & \multicolumn{2}{|c|}{ Sample-Controls } \\
\hline & All firms & Sample & Controls & Sample & Controls & Sample & Controls & $\begin{array}{l}\text { t-stats } \\
\text { means }\end{array}$ & $\begin{array}{c}\text { Wilcoxon } \\
\text { medians }\end{array}$ \\
\hline \multicolumn{10}{|l|}{ Number of articles } \\
\hline Confident & 184 & 49 & 135 & 0.98 & 0.55 & 0.5 & 0 & $2.88 * * *$ & $2.17 * *$ \\
\hline Cautious & 98 & 13 & 85 & 0.26 & 0.35 & 0 & 0 & -0.68 & 0.67 \\
\hline Total & 282 & 62 & 220 & & & & & & \\
\hline Number of observations & 296 & 50 & 246 & 50 & 246 & 50 & 246 & & \\
\hline
\end{tabular}

Panel B: Articles in the year before the CEO started earning a dollar-a-year salary

\begin{tabular}{|c|c|c|c|c|c|c|c|c|c|}
\hline & \multicolumn{3}{|c|}{ Total Number of articles } & \multicolumn{2}{|c|}{$\begin{array}{l}\text { Average number of } \\
\text { articles }\end{array}$} & \multicolumn{2}{|c|}{$\begin{array}{l}\text { Median number of } \\
\text { articles }\end{array}$} & \multicolumn{2}{|c|}{ Sample-Controls } \\
\hline & All firms & Sample & Controls & Sample & Controls & Sample & Controls & $\begin{array}{l}\text { t-stats } \\
\text { means }\end{array}$ & $\begin{array}{l}\text { Wilcoxon } \\
\text { medians }\end{array}$ \\
\hline \multicolumn{10}{|l|}{ Number of articles } \\
\hline Confident & 127 & 31 & 96 & 0.62 & 0.39 & 0 & 1 & $1.85^{*}$ & 1.40 \\
\hline Cautious & 50 & 2 & 48 & 0.04 & 0.20 & 0 & 0 & $-1.74 *$ & $-1.73^{*}$ \\
\hline Total & 177 & 33 & 144 & & & & & & \\
\hline Number of observations & 296 & 50 & 246 & 50 & 246 & 50 & 246 & & \\
\hline
\end{tabular}




\section{Table 12: Value Effects of Adoptions of \$1 CEO Salaries}

\section{Panel A: Three-year post-performance after the adoption of \$1 CEO salary}

Sample firms are not repeated. Whenever the CEO of a sample firm earns a \$1 (or less) salary for more than 1 consecutive year, only the first year is considered. Control firms are from the CRSP/ Compustat universe, matched with sample firms by 4-digit SIC codes and year. All variables are defined in Appendix B. The last two columns show t-stats and Wilcoxon-stats from the tests of equality of means and medians, respectively. *, $* *, * * *$ stand for statistical significance at $10 \%, 5 \%$, and $1 \%$ levels, respectively.

\begin{tabular}{lccc|ccc|cc}
\hline & \multicolumn{4}{c}{ Sample Firms } & \multicolumn{3}{c}{ Control Firms } & \multicolumn{2}{c}{ Sample - Controls } \\
\cline { 2 - 10 } Measure & Mean & N & $\mathbf{5 0 t h}$ Pctl & Mean & N & 50th Pctl & $\begin{array}{c}\text { t-stats } \\
\text { means }\end{array}$ & $\begin{array}{c}\text { Wilcoxon } \\
\text { medians }\end{array}$ \\
\hline LT abnormal ret & -0.023 & 43 & -0.225 & 0.197 & 242 & -0.031 & -0.84 & $-1.72 *$ \\
LT CAR & -0.083 & 43 & 0.143 & 0.344 & 242 & 0.295 & $-3.40 * * *$ & $-2.55^{* * *}$ \\
Alpha $\left(10^{\wedge} 3\right)$ & -0.138 & 44 & 0.400 & 0.7682 & 207 & 0.7226 & $-3.57 * * *$ & $-2.79 * * *$ \\
\hline
\end{tabular}

\section{Panel B: Long-term performance - calendar time approach}

This calendar time analysis is based on monthly returns. Data are from CRSP/ Compustat. Sample firms are those in which the CEO earns a salary of $\$ 1$ (or less). Sample firms are not repeated. Whenever the CEO earns $\$ 1$ (or less) for more than one consecutive year, only the first year is considered. Control firms are the matched firms from the same 4-digit SIC code in the same year as the adoption of the \$1 CEO salary. The dependent variable is the equally-weighted monthly return (of a portfolio of sample firms, control firms, or the difference between the two) minus the risk-free rate and the independent variable is the CRSP value-weighted return index minus the risk-free rate. Returns are computed starting from January of the first year post adoption of a $\$ 1$ CEO salary to one and three years later, as indicated. T-stats (absolute values) are shown in parenthesis. *,**, and *** stand for statistical significance at $10 \%, 5 \%$, and $1 \%$ levels, respectively.

\begin{tabular}{|c|c|c|c|c|c|c|}
\hline & \multicolumn{3}{|c|}{ One year post adoption of \$1 salary } & \multicolumn{3}{|c|}{ Three years post adoption of $\$ 1$ salary } \\
\hline & Sample & Controls & Sample - Controls & Sample & Controls & Sample - Controls \\
\hline \multirow[t]{2}{*}{ Alpha } & 0.001 & 0.001 & -0.007 & -0.002 & 0.004 & $-0.010 * *$ \\
\hline & $(0.11)$ & $(0.20)$ & $(1.28)$ & $(0.32)$ & $(1.21)$ & $(2.11)$ \\
\hline \multirow[t]{2}{*}{ Excess market return } & $1.436 * * *$ & $1.270 * * *$ & -0.051 & $1.319 * * *$ & $1.180 * * *$ & -0.002 \\
\hline & $(8.60)$ & (13.06) & $(0.38)$ & (11.88) & $(16.41)$ & $(0.02)$ \\
\hline Observations & 168 & 168 & 168 & 192 & 192 & 192 \\
\hline R-squared & 0.31 & 0.51 & 0.001 & 0.43 & 0.59 & $<0.001$ \\
\hline
\end{tabular}




\section{Table 12: Value Effects of Adoptions of \$1 CEO Salaries, Continued}

\section{Panel C: Regressions of Tobin's $Q$}

The observations used in these regressions include sample firms and control firms. Sample firms are those in which the CEO earns a salary of $\$ 1$ (or less). Sample firms are not repeated. Whenever the CEO earns $\$ 1$ (or less) for more than one consecutive year, only the first year is considered. Control firms are from the CRSP/Compustat universe, matched with sample firms by 4-digit SIC codes and year. Data are mainly from Compustat and Execucomp. All variables in dollars are adjusted to reflect 2005 prices. To control for selection bias affecting firms, which CEOs earn a salary of \$1 (or less), we use Heckman's (1979) procedure. The firststage regression (selection equation) is a probit model that estimates the likelihood of a firm having a $\$ 1 \mathrm{CEO}$. The dependent variable is a dummy that equals 1 if the CEO of a firm earns $\$ 1$ (or less) and zero otherwise. The dependent variable in the second-stage equations (valuation equations) is the Tobin's q as of the fiscal-year end (winsorized at the 1\% and 99\% percentiles). All variables are defined in Appendix B. White-robust t-stats (absolute values) are shown in parenthesis. *, **, and *** stand for statistical significance at 10\%, 5\%, and $1 \%$ levels, respectively.

\begin{tabular}{|c|c|c|c|}
\hline \multirow{3}{*}{ Log total assets (t-1) } & \multirow[b]{2}{*}{$\begin{array}{c}\text { Tobin's Q } \\
(1)\end{array}$} & \multicolumn{2}{|c|}{ Tobin's Q regressions corrected for sample } \\
\hline & & $\begin{array}{c}\text { Tobin's Q } \\
(2)\end{array}$ & $\begin{array}{l}\text { Selection equation Dep } \\
\text { Variable: } \$ 1 \text { CEO } \\
(3)\end{array}$ \\
\hline & $\begin{array}{l}-0.021 \\
(0.14)\end{array}$ & $\begin{array}{r}-0.049 \\
(0.35)\end{array}$ & $\begin{array}{l}-0.001 \\
(0.07)\end{array}$ \\
\hline $\mathrm{ROA}(\mathrm{t}-1)$ & $\begin{array}{c}12.086^{* * * *} \\
(4.54)\end{array}$ & $\begin{array}{c}12.361^{* * *} \\
(4.61)\end{array}$ & $\begin{array}{c}-0.173 \\
(0.99)\end{array}$ \\
\hline Leverage $(\mathrm{t}-1)$ & $\begin{array}{c}-4.201 * * * \\
(4.85)\end{array}$ & $\begin{array}{c}-5.427 * * * \\
(4.56)\end{array}$ & $\begin{array}{c}0.270^{*} \\
(1.87)\end{array}$ \\
\hline Assets growth (past 3-year average) & $\begin{array}{c}0.421 * \\
(1.75)\end{array}$ & $\begin{array}{l}0.285 \\
(1.10)\end{array}$ & $\begin{array}{l}0.015 \\
(1.03)\end{array}$ \\
\hline Prct Shares owned by the CEO & $\begin{array}{l}0.030 \\
(1.06)\end{array}$ & $\begin{array}{r}-0.026 \\
(0.87)\end{array}$ & $\begin{array}{c}0.006^{* *} \\
(2.30)\end{array}$ \\
\hline$\$ 1 \mathrm{CEO}$ & $\begin{array}{c}-0.807 * * \\
(2.03)\end{array}$ & $\begin{array}{c}-1.171^{* *} \\
(2.54)\end{array}$ & \\
\hline Institutional ownership & & & $\begin{array}{c}-0.263 * * \\
(2.09)\end{array}$ \\
\hline Constant & $\begin{array}{c}4.799 * * * \\
(4.45)\end{array}$ & $\begin{array}{c}8.684^{* * *} \\
(4.35)\end{array}$ & \\
\hline Lambda & & $\begin{array}{c}-1.652^{* *} \\
(2.28)\end{array}$ & \\
\hline Board size & & & $\begin{array}{l}-0.010 \\
(1.09)\end{array}$ \\
\hline Prct independents & & & $\begin{array}{l}0.084 \\
(0.54)\end{array}$ \\
\hline Top tercile - Value of CEO shares & & & $\begin{array}{c}0.201 * * * \\
(3.45)\end{array}$ \\
\hline Observations & 257 & 257 & 262 \\
\hline R-squared & 0.29 & 0.31 & \\
\hline Pseudo R-squared & & & 0.20 \\
\hline Actual Prob. & & & 0.18 \\
\hline
\end{tabular}


Table 13: Potential for Public Outrage over CEO Benefits from Firm

\begin{tabular}{|c|c|c|c|c|c|}
\hline Company & CEO & $\begin{array}{l}\text { The } 1^{\text {st }} \\
\text { year of } \\
\text { \$1 CEO }\end{array}$ & Possible reasons for outrage at year $t-1$ & $\begin{array}{l}\text { The last } \\
\text { year of } \\
\$ 1 \text { CEO }\end{array}$ & Possible reasons for dropping the $\$ 1$ salary \\
\hline $\begin{array}{l}\text { Lawter } \\
\text { International }\end{array}$ & $\begin{array}{l}\text { Daniel J. } \\
\text { Terra }\end{array}$ & 1993 & Lawter's stock has languished for two years. & 1995 & $\begin{array}{l}\text { 1) Earnings jumped to a record in } 1994 . \\
\text { 2) Mr. Terra retired on Dec. } 31,1995 .\end{array}$ \\
\hline Triarc & $\begin{array}{l}\text { Nelson } \\
\text { Peltz }\end{array}$ & 1994 & $\begin{array}{l}\text { 1) The company was struggling when bought by Mr. } \\
\text { Peltz in } 1993 \text {. } \\
\text { 2) A former CEO was forced to reduce his high pay } \\
\text { when he led the firm into heavy debt. } \\
\text { 3) Mr. Peltz's previous high pay at another company, } \\
\text { Triangle, attracted notice in the media. }\end{array}$ & 1998 & $\begin{array}{l}\text { 1) After several divestures and acquisitions, } \\
\text { management had resolved to turn Triarc into a } \\
\text { branded consumer products company in } 1997 . \\
\text { 2) Prior compensation arrangements for Mr. Peltz } \\
\text { expired in April } 1999 \text { and new compensation } \\
\text { arrangements were made. }\end{array}$ \\
\hline El Paso Corp & $\begin{array}{l}\text { William A. } \\
\text { Wise }\end{array}$ & 1996 & The firm initiated a company-wide cost reduction plan. & 1998 & $\begin{array}{l}\text { 1) Sales and net income increased in } 1997-1998 . \\
\text { 2) Mr. Wise's base salary was reinstated in } \\
\text { connection with the merger with Sonat. }\end{array}$ \\
\hline Masco Corp & $\begin{array}{l}\text { Richard A. } \\
\text { Manoogian }\end{array}$ & 1996 & $\begin{array}{l}\text { 1) Mr. Manoogian's high pay was often mentioned in } \\
\text { the press. } \\
\text { 2) The stock performance was disappointing. }\end{array}$ & 1999 & $\begin{array}{l}\text { The stock price increased steadily after } 1995 \text { and } \\
\text { peaked in } 1999 .\end{array}$ \\
\hline Autonation Inc & $\begin{array}{l}\text { H. Wayne } \\
\text { Huizenga }\end{array}$ & 1996 & $\begin{array}{l}\text { Mr. Huizenga didn't want to be accused of having two } \\
\text { companies competing for his time and attention. }\end{array}$ & 1997 & $\begin{array}{l}\text { Mr. Huizenga proved his capability with a huge } \\
\text { increase in stock price in } 1996 .\end{array}$ \\
\hline L A Gear Inc & $\begin{array}{l}\text { Stanley P. } \\
\text { Gold }\end{array}$ & 1996 & $\begin{array}{l}\text { 1) The company was struggling. } \\
\text { 2) The former CEO, Mr Greenberg, initiated a salary } \\
\text { cut, but was not considered to be enough. }\end{array}$ & 1996 & $\begin{array}{l}\text { Mr. Gold resigned in } 1997 \text { when Trefoil Capital } \\
\text { Investors, L.P., who had appointed the CEO, sold } \\
\text { out its } 42 \% \text { stake of the company. }\end{array}$ \\
\hline Viacom & $\begin{array}{l}\text { Sumner M. } \\
\text { Redstone }\end{array}$ & 1996 & $\begin{array}{l}\text { Mr. Redstone was involved in a divorce process with } \\
\text { his wife Phyllis Redstone. }\end{array}$ & 1999 & $\begin{array}{l}\text { 1) Mr. Redstone was divorced from his wife in } \\
1999 . \\
\text { 2) The Company entered into employment } \\
\text { agreements with Redstone after the CBS merger. }\end{array}$ \\
\hline $\begin{array}{l}\text { Fruit Of The } \\
\text { Loom Ltd }\end{array}$ & $\begin{array}{l}\text { William F. } \\
\text { Farley }\end{array}$ & 1997 & $\begin{array}{l}\text { 1) Mr. Farley's higher pay attracted notice in the past. } \\
\text { 2) The firm was under restructuring, closing down } 23 \\
\text { plants and laying off } 8,000 \text { employees. }\end{array}$ & 1997 & $\begin{array}{l}\text { Mr. Farley took } \$ 550,000 \text { for the additional duties } \\
\text { of President and Chief Operating Officer in } 1998 .\end{array}$ \\
\hline $\begin{array}{l}\text { Netscape } \\
\text { Communication }\end{array}$ & $\begin{array}{l}\text { James L. } \\
\text { Barksdale }\end{array}$ & 1997 & $\begin{array}{l}\text { The company had a big loss in sales and was planning } \\
\text { to cut } 400 \text { jobs. }\end{array}$ & 1998 & Netscape was acquired by America Online in 1999. \\
\hline Apple Inc & $\begin{array}{l}\text { Steven P. } \\
\text { Jobs }\end{array}$ & 1998 & $\begin{array}{l}\text { The former CEO, Gil Amelio, was ousted by the board } \\
\text { of directors after crippling financial losses. }\end{array}$ & Till now & N/A \\
\hline Metaldyne Corp & $\begin{array}{l}\text { Frank M. } \\
\text { Hennessey }\end{array}$ & 1998 & Company's stock price performance was disappointing. & 1999 & $\begin{array}{l}\text { Mr. Hennessey stepped down upon the } 2000 \\
\text { recapitalization. }\end{array}$ \\
\hline
\end{tabular}




\begin{tabular}{|c|c|c|c|c|c|}
\hline Company & CEO & $\begin{array}{l}\text { The } 1^{\text {st }} \\
\text { year of } \\
\text { \$1 CEO }\end{array}$ & Possible reasons for outrage at year $\mathrm{t}-1$ & $\begin{array}{l}\text { The last } \\
\text { year of } \\
\$ 1 \text { CEO }\end{array}$ & Possible reasons for dropping the $\$ 1$ salary \\
\hline Pepsico Inc & $\begin{array}{l}\text { Roger A. } \\
\text { Enrico }\end{array}$ & 1998 & $\begin{array}{l}\text { PepsiCo's important international beverage operations } \\
\text { ran into trouble. }\end{array}$ & 2000 & $\begin{array}{l}\text { Mr. Enrico stepped down when PepsiCo’s } \$ 13 \\
\text { billion acquisition of Quaker Oats Co. was done. }\end{array}$ \\
\hline Oracle Corp & $\begin{array}{l}\text { Lawrence } \\
\text { J. Ellison }\end{array}$ & 2000 & $\begin{array}{l}\text { Previous year's high pay attracted notice (ranked as \#2 } \\
\text { in Forbes). }\end{array}$ & 2003 & $\begin{array}{l}\text { Mr. Ellison was ranked 494th in the Forbes' } \\
\text { Executive Pay and 9th in the Forbes } 400 \text { Richest in } \\
\text { America in } 2003 .\end{array}$ \\
\hline Conseco Inc & $\begin{array}{l}\text { Gary C. } \\
\text { Wendt }\end{array}$ & 2000 & $\begin{array}{l}\text { 1) Mr. Wendt's } \$ 45 \mathrm{~m} \text {. "golden hello" and options } \\
\text { worth over } \$ 20 \mathrm{~m} \text { attracted press notice. } \\
\text { 2) His ex-wife got } \$ 20 \text { million in parting, but had } \\
\text { appealed and sought an additional } \$ 30 \text { million. }\end{array}$ & 2001 & $\begin{array}{l}\text { 1) In 2002, the company entered Chapter } 11 \\
\text { reorganization and Wendt resigned as CEO. } \\
\text { 2) His ex-wife's appeal for additional money was } \\
\text { turned down in April } 2000 \text {. }\end{array}$ \\
\hline $\begin{array}{l}\text { Plains } \\
\text { Resources Inc }\end{array}$ & $\begin{array}{l}\text { James C. } \\
\text { Flores }\end{array}$ & 2001 & The firm was in trouble in the previous year. & 2001 & Mr. Flores resigned as CEO in 2002. \\
\hline $\begin{array}{l}\text { Siebel Systems } \\
\text { Inc }\end{array}$ & $\begin{array}{l}\text { Thomas M. } \\
\text { Siebel }\end{array}$ & 2001 & The profits declined. & 2003 & $\begin{array}{l}\text { The previous agreement on the salary cut expired } \\
\text { after } 3 \text { years. }\end{array}$ \\
\hline $\begin{array}{l}\text { Bank Of Hawaii } \\
\text { Corp }\end{array}$ & $\begin{array}{l}\text { Michael E. } \\
\text { O'Neill }\end{array}$ & 2002 & The company was under restructuring. & 2004 & $\begin{array}{l}\text { Mr. O'Neill departed the company on September 1, } \\
2004 \text { after achieving the turnaround. }\end{array}$ \\
\hline Ford Motor Co & $\begin{array}{l}\text { William C. } \\
\text { Ford, Jr. }\end{array}$ & 2002 & The company announced to cut 35,000 jobs. & 2006 & Ford appointed a new CEO in Sep. 2006. \\
\hline Lilly (Eli) \& Co & $\begin{array}{l}\text { Sidney } \\
\text { Taurel }\end{array}$ & 2002 & $\begin{array}{l}\text { Eli Lilly was making substantial cutbacks in } 2002 \\
\text { following the loss of patent protection for its top- } \\
\text { selling antidepressant, Prozac. The company froze } \\
\text { salaries for its employees in } 2002 \text { at } 2001 \text { levels. }\end{array}$ & 2002 & $\begin{array}{l}\text { In recognition of his strong leadership and many } \\
\text { contributions in a challenging year for the } \\
\text { company, the company established Mr. Taurel's } \\
\text { salary at } \$ 1.43 \text { million in } 2003 \text {. }\end{array}$ \\
\hline COGNEX Corp & $\begin{array}{l}\text { Robert J. } \\
\text { Shillman }\end{array}$ & 2002 & There was a slowdown in the Corporation's business. & Till now & N/A \\
\hline $\begin{array}{l}\text { Cisco Systems } \\
\text { Inc }\end{array}$ & $\begin{array}{l}\text { John T. } \\
\text { Chambers }\end{array}$ & 2002 & $\begin{array}{l}\text { The company was in the process of eliminating } 8,500 \\
\text { positions to offset falling revenues and earnings. }\end{array}$ & 2004 & $\begin{array}{l}\text { After restructuring, the company was back in a } \\
\text { strong position. }\end{array}$ \\
\hline $\begin{array}{l}\text { Franklin Covey } \\
\text { Co }\end{array}$ & $\begin{array}{l}\text { Robert A. } \\
\text { Whitman }\end{array}$ & 2002 & The Company reported a decline in its revenues. & 2003 & The Company's performance improved in 2003. \\
\hline $\begin{array}{l}\text { Micron } \\
\text { Technology Inc }\end{array}$ & $\begin{array}{l}\text { Steven R. } \\
\text { Appleton }\end{array}$ & 2003 & $\begin{array}{l}\text { In the previous year, the firm froze its hiring and cut } \\
\text { the pay of its management team. }\end{array}$ & 2003 & Profits increased in 2003. \\
\hline $\begin{array}{l}\text { Duke Energy } \\
\text { Corp }\end{array}$ & $\begin{array}{l}\text { Paul M. } \\
\text { Anderson }\end{array}$ & 2004 & $\begin{array}{l}\text { In the previous year, the company cut } 2,000 \text { jobs -- } \\
\text { about } 8 \text { percent of its work force. }\end{array}$ & Till now & N/A \\
\hline Google Inc & $\begin{array}{l}\text { Eric E. } \\
\text { Schmidt }\end{array}$ & 2005 & $\begin{array}{l}\text { Mr. Schmidt's significant ownership and voting power } \\
\text { attracted press attention. }\end{array}$ & Till now & N/A \\
\hline
\end{tabular}




\section{Table 14: Alternative Controls - All Other Firms in Execucomp}

The regressions include sample firms and control firms. Sample firms are those which CEO earns a salary of $\$ 1$ (or less). Sample firms are not repeated: whenever the CEO earns $\$ 1$ (or less) for more than one consecutive year, only the first year is considered. Control firms are all firms from CRSP/Compustat universe. The dependent variable is a dummy variable that equals 1 when the CEO earns a salary of $\$ 1$ (or less), and 0 otherwise. All variables are defined in Appendix B. The table reports marginal effects of the probit regressions. White-robust t-stats (absolute value) are shown in parenthesis. $*$, **, and *** stand for statistical significance at $10 \%, 5 \%$, and $1 \%$, respectively.

Panel A : Probit regressions - "Signaling” and "Managerial Power" Hypotheses

\begin{tabular}{|c|c|c|c|c|c|c|c|}
\hline & $(1)$ & $(2)$ & (3) & $(4)$ & (5) & $(6)$ & (7) \\
\hline Log total assets (t-1) & $\begin{array}{c}0.001 * * * \\
(6.66)\end{array}$ & $\begin{array}{c}0.001 * * * \\
(5.37)\end{array}$ & $\begin{array}{c}0.001 * * * \\
(6.78)\end{array}$ & $\begin{array}{c}0.001 * * * \\
(9.53)\end{array}$ & $\begin{array}{c}0.001 * * * \\
(10.39)\end{array}$ & $\begin{array}{c}0.001 * * * \\
(11.30)\end{array}$ & $\begin{array}{c}0.001 * * * \\
(11.34)\end{array}$ \\
\hline $\mathrm{ROA}(\mathrm{t}-1)$ & $\begin{array}{c}-0.000 * * \\
(2.11)\end{array}$ & $\begin{array}{c}-0.000 * \\
(1.79)\end{array}$ & $\begin{array}{c}-0.000 * * * \\
(2.64)\end{array}$ & $\begin{array}{l}-0.000 \\
(1.15)\end{array}$ & $\begin{array}{c}-0.000 * \\
(1.94)\end{array}$ & $\begin{array}{l}-0.000 \\
(1.52)\end{array}$ & $\begin{array}{c}-0.000 * * \\
(2.01)\end{array}$ \\
\hline Leverage $(\mathrm{t}-1)$ & $\begin{array}{l}0.000 \\
(0.29)\end{array}$ & $\begin{array}{l}0.000 \\
(0.30)\end{array}$ & $\begin{array}{l}0.000 \\
(0.31)\end{array}$ & $\begin{array}{l}0.000 \\
(1.25)\end{array}$ & $\begin{array}{c}0.000 * \\
(1.72)\end{array}$ & $\begin{array}{l}0.000 \\
(1.38)\end{array}$ & $\begin{array}{l}0.000^{*} \\
(1.69)\end{array}$ \\
\hline Assets growth (past 3-year average) & $\begin{array}{l}0.000 \\
(0.24)\end{array}$ & $\begin{array}{l}0.000 \\
(0.27)\end{array}$ & $\begin{array}{l}-0.000 \\
(0.23)\end{array}$ & $\begin{array}{l}-0.000 \\
(0.47)\end{array}$ & $\begin{array}{l}-0.001 \\
(1.62)\end{array}$ & $\begin{array}{l}-0.002 \\
(1.58)\end{array}$ & $\begin{array}{c}-0.002 * \\
(1.96)\end{array}$ \\
\hline Prct shares owned by the CEO & $\begin{array}{c}0.000 * * * \\
(4.38)\end{array}$ & $\begin{array}{c}0.000 * * * \\
(4.68)\end{array}$ & $\begin{array}{c}0.000 * * * \\
(4.43)\end{array}$ & $\begin{array}{c}0.000 * * * \\
(2.60)\end{array}$ & $\begin{array}{c}0.000 * * \\
(2.52)\end{array}$ & $\begin{array}{c}0.000 * * \\
(2.57)\end{array}$ & $\begin{array}{c}0.000 * * \\
(2.52)\end{array}$ \\
\hline Top tercile - Value of CEO shares & $\begin{array}{c}0.007 * * * \\
(9.36)\end{array}$ & $\begin{array}{c}0.008 * * * \\
(8.92)\end{array}$ & $\begin{array}{c}0.007 * * * \\
(9.07)\end{array}$ & $\begin{array}{c}0.010 * * * \\
(5.79)\end{array}$ & $\begin{array}{c}0.009 * * * \\
(5.60)\end{array}$ & $\begin{array}{c}0.009 * * * \\
(5.77)\end{array}$ & $\begin{array}{c}0.008 * * * \\
(5.66)\end{array}$ \\
\hline Institutional Ownership & & & & $\begin{array}{c}-0.000^{*} \\
(1.74)\end{array}$ & $\begin{array}{c}-0.000^{*} \\
(1.70)\end{array}$ & $\begin{array}{c}-0.000 * \\
(1.87)\end{array}$ & $\begin{array}{c}-0.000 * \\
(1.84)\end{array}$ \\
\hline Board size & & & & $\begin{array}{c}-0.001 * * * \\
(7.06)\end{array}$ & $\begin{array}{c}-0.001 * * * \\
(7.20)\end{array}$ & $\begin{array}{c}-0.001 * * * \\
(7.40)\end{array}$ & $\begin{array}{c}-0.001 * * * \\
(7.38)\end{array}$ \\
\hline Prct independents & & & & $\begin{array}{c}-0.000 * * \\
(2.25)\end{array}$ & $\begin{array}{c}-0.000 * * * \\
(2.94)\end{array}$ & $\begin{array}{c}-0.000 * * * \\
(2.67)\end{array}$ & $\begin{array}{c}-0.000 * * * \\
(3.03)\end{array}$ \\
\hline Independent committee & & & & $\begin{array}{l}0.001 \\
(0.96)\end{array}$ & $\begin{array}{l}0.001 \\
(1.09)\end{array}$ & $\begin{array}{l}0.001 \\
(1.05)\end{array}$ & $\begin{array}{l}0.001 \\
(1.12)\end{array}$ \\
\hline Presence of a blockholder & & & & $\begin{array}{c}-0.002 * * * \\
(3.00)\end{array}$ & $\begin{array}{c}-0.002 * * * \\
(3.05)\end{array}$ & $\begin{array}{c}-0.002^{* * * *} \\
(2.90)\end{array}$ & $\begin{array}{c}-0.002 * * * \\
(3.00)\end{array}$ \\
\hline Change capex $(-1,+2)$ & & $\begin{array}{l}0.000 \\
(1.46)\end{array}$ & & & & & \\
\hline Tobin's Q (t-1) & & & & & $\begin{array}{c}0.001 * * * \\
(3.89)\end{array}$ & & $\begin{array}{c}0.000 * * * \\
(3.19)\end{array}$ \\
\hline LT abnormal ret (past 3 years) & & & $\begin{array}{l}0.000 \\
(1.29)\end{array}$ & & & $\begin{array}{c}0.000 * \\
(1.89)\end{array}$ & $\begin{array}{l}0.000 \\
(1.17)\end{array}$ \\
\hline Year fixed-effects & yes & yes & yes & yes & yes & yes & yes \\
\hline Industry fixed-effects (SIC 2dig) & yes & yes & yes & yes & yes & yes & yes \\
\hline Observations & 14508 & 11167 & 14498 & 5819 & 5818 & 5819 & 5818 \\
\hline Pseudo R-squared & 0.19 & 0.20 & 0.20 & 0.29 & 0.30 & 0.30 & 0.30 \\
\hline Actual Prob. & 0.01 & 0.01 & 0.01 & 0.01 & 0.01 & 0.01 & 0.01 \\
\hline
\end{tabular}




\section{Table 14: Alternative Controls - All Other Firms in Execucomp, Continued}

Panel B: Long-term performance-calendar time approach (non-matched control sample)

This calendar time analysis is based on monthly returns. Data are from CRSP/ Compustat. Sample firms are those in which the CEO earns a salary of $\$ 1$ (or less). Sample firms are not repeated. Whenever the CEO earns $\$ 1$ (or less) for more than one consecutive year, only the first year is considered. Control firms are all firms from the CRSP/Compustat universe. The dependent variable is the equally-weighted monthly return (of a portfolio of sample firms, control firms, or the difference between the two) minus the risk-free rate and the independent variable is the CRSP value-weighted return index minus the risk-free rate. Returns are computed starting from January of the first year post the adoption of a \$1 CEO salary to one and three years later, as indicated. T-stats (absolute values) are shown in parenthesis. *,**, and *** stand for statistical significance at $10 \%, 5 \%$, and $1 \%$ levels, respectively.

\begin{tabular}{|c|c|c|c|c|c|c|}
\hline & \multicolumn{3}{|c|}{ One year post adoption of $\$ 1$ salary } & \multicolumn{3}{|c|}{ Three years post adoption of $\$ 1$ salary } \\
\hline & Sample & Controls & Sample - Controls & Sample & Controls & Sample - Controls \\
\hline \multirow[t]{2}{*}{ Alpha } & 0.001 & $0.005 * * *$ & -0.007 & -0.002 & $0.004 * *$ & $-0.009 *$ \\
\hline & $(0.11)$ & $(2.91)$ & $(1.09)$ & $(0.32)$ & $(2.53)$ & $(1.89)$ \\
\hline \multirow[t]{2}{*}{ Excess market return } & $1.436 * * *$ & $0.990 * * *$ & $0.445 * * *$ & $1.319 * * *$ & $1.027 * * *$ & $0.288 * * *$ \\
\hline & $(8.60)$ & $(24.03)$ & $(2.75)$ & $(11.88)$ & $(27.06)$ & $(2.70)$ \\
\hline Observations & 168 & 168 & 168 & 192 & 192 & 192 \\
\hline R-squared & 0.31 & 0.78 & 0.04 & 0.43 & 0.79 & 0.04 \\
\hline
\end{tabular}


Table 15: Additional analyses: Bankruptcies, mergers, and delistings (next three years)

Sample firms are not repeated: whenever the CEO of a sample firm earns a \$1 (or less) salary for more than 1 consecutive year, only the first year is considered. Control firms are from the CRSP/ Compustat universe, matched with sample firms by 4-digit SIC codes and year. Data on bankruptcies, mergers and other delistings are from Execucomp. The last two columns show t-stats and Wilcoxon-stats from the tests of equality of means and medians, respectively. $* * *, * * *$ stand for statistical significance at $10 \%, 5 \%$, and $1 \%$, respectively.

\begin{tabular}{|c|c|c|c|c|c|}
\hline & \multicolumn{2}{|c|}{ Sample firms $(\mathrm{N}=50)$} & \multicolumn{2}{|c|}{ Control Firms $(N=246)$} & \multirow{2}{*}{\begin{tabular}{|c} 
Sample - Controls \\
t-stats means \\
\end{tabular}} \\
\hline & $\mathbf{N}$ & $\%$ & $\mathbf{N}$ & $\%$ & \\
\hline Bankruptcies & 3 & $6.00 \%$ & 0 & $0.00 \%$ & $2.96^{* * *}$ \\
\hline Mergers & 6 & $12.00 \%$ & 30 & $12.20 \%$ & -0.41 \\
\hline Delistings & 11 & $22.00 \%$ & 33 & $13.41 \%$ & $2.32 * *$ \\
\hline
\end{tabular}


Figure 1

ROA in the years surrounding Adoptions of \$1 CEO salaries

Year " $\mathrm{t}$ " is the year of adoption of a \$1 CEO salary. The return on assets is based on operating income after depreciation. Sample firms are the ones adopting \$1 CEO salaries.

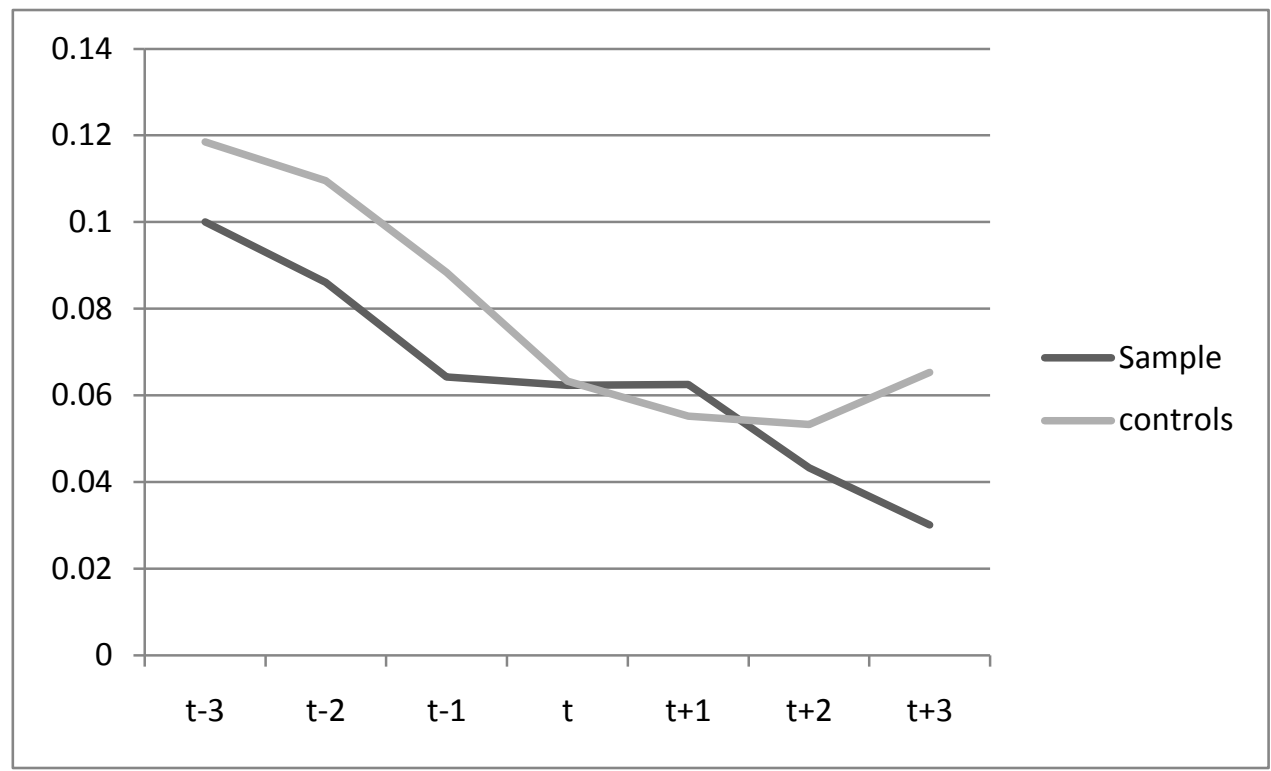

